\title{
Aconselhamento pré e pós-teste anti-HIV na atenção básica: a perspectiva dos profissionais de saúde
}

Dissertação apresentada à Faculdade de Medicina da Universidade de São Paulo, para obtenção do título de Mestre em Ciências

Programa de Medicina Preventiva

Orientadora: Prof ${ }^{a}$. Dr ${ }^{a}$. Ana Flávia Pires Lucas d'Oliveira

São Paulo 2012 
Dados Internacionais de Catalogação na Publicação (CIP)

Preparada pela Biblioteca da

Faculdade de Medicina da Universidade de São Paulo

Creprodução autorizada pelo autor

Zakabi, Denise

Aconselhamento pré e pós-teste anti-HIV na atenção básica: a perspectiva dos profissionais de saúde / Denise Zakabi. -- São Paulo, 2012.

Dissertação(mestrado)--Faculdade de Medicina da Universidade de São

Paulo. Programa de Medicina Preventiva.

Orientadora: Ana Flávia Pires Lucas d'Oliveira.

Descritores: 1.HIV 2.Síndrome de imunodeficiência adquirida 3.Aconselhamento 4.Acolhimento 5.Atenção primária à saúde

USP/FM/DBD-357/12 
Ao meu pai e à minha mãe,

Pelo apoio durante o mestrado e toda a minha formação. 


\section{AGRADECIMENTOS}

À CNPQ, pelo período que usufrui da bolsa de pesquisa.

À Ana Flávia Pires Lucas d'Oliveira, minha querida orientadora, pela compreensão, disponibilidade e valiosas sugestões.

À Faculdade de Medicina da USP, particularmente, ao Departamento de Medicina Preventiva e a todos os funcionários, pela oportunidade de pesquisa.

Aos gerentes e profissionais de saúde participantes da pesquisa.

À Veroca (Vera Paiva), por ser minha "madrinha" na área acadêmica, por me mostrar o prazer de ser pesquisadora e me ajudar a construir meu próprio caminho durante o início de mestrado e, particularmente, durante a qualificação.

Ao José Ricardo Ayres, um exemplo de professor, pela sua sabedoria e compromisso ético e que me orgulho muito por ter sido meu orientador em minha primeira pesquisa. Agradeço pelas ótimas contribuições durante a qualificação.

Ao Ricardo Rodrigues Teixeira, pelas ótimas contribuições na concepção deste trabalho e na análise.

Aos professores Lilia Blima Schraiber; Márcia Thereza Couto Falcão; Denise Dias Barros; Marcelo Afonso Ribeiro; Alessandro; Arley; e Belinda, pelos ótimos conhecimentos.

Aos professores Heráclito Barbosa de Carvalho; Paulo Rossi Menezes; e Hillegonda Maria Dutilh Novaes, pelo apoio durante o mestrado.

À Lilian Santos de Godoy Prado, por ser sempre atenciosa, simpática e eficiente. 
À Malu (Maria Luisa Sandoval Schmidt), por suas ótimas aulas e ótima supervisão de estágio PAE.

À Bader Burihan Sawaia, pelas ótimas aulas e sugestões na qualificação.

À Maria Helena Lópes de Campos Isaac, Paulo e Maria Luiza - Supervisão do Butantã; à Marylda Alves Silva - chefe do Distrito de Saúde Secretaria Executiva Regional III; e à Ana Paula Cavalcante Ramalho Brilhante - Coordenadora do Sistema Municipal de Saúde Escola de Fortaleza, pelas autorizações para pesquisa.

À Coordenação Municipal de DST/Aids e hepatites virais de Fortaleza, especialmente Renata Mota, Thiago, Cícera, Malena, Diego, Evilene, Aolanda e Neta, pelo acolhimento.

À Ivone Aparecida de Paula e ao Artur Kalichman, da Coordenação Estadual de DST/Aids de São Paulo, pelas informações fornecidas.

À Luciane Martins A. de Matos, do Comitê de Ética da Prefeitura, pela simpatia, gentileza e eficiência.

À Escola de Saúde Pública do Ceará, especialmente Alice Pequeno; Catia Albertin; Nádia N. Gomes; Raquel P. Ramos; Helen C. Hilário; à UFC Virtual, especialmente ao Marcelo Natividade; Aline e demais membros; ao Centro de Referência LGBT, especialmente à Luanna Marley, Pedro, Adriana, Paula, Marfisa e Rosi pelo apoio para escrita do mestrado.

Ao Marcelo Lábaki Agostinho, pelas sugestões no projeto de mestrado.

Aos Nepaidianos, pelo apoio e reflexões para o mestrado: Diva Moreno; Lígia Pupo; Neide; Luzia; Renata; Ivan; Cely; e Bruna.

À Lygia França, pelos conhecimentos. 
Aos colegas do grupo Conexões, especialmente Ianni e Adriana, pelas dicas de mestrado.

À Dulce Maria Senna e à Ana Silvia Whitaker Dalmaso, minha eterna gratidão pela formação desde o aprimoramento.

À Andrea, por sua amizade, apoio e valiosas dicas para o mestrado.

À Maria Inês de França Roland e à Camila Monteiro pelas importantes informações durante o mestrado e pela amizade.

Aos queridos "apris" Daiana, Fernando, Juliana, Talita, Thaís e nossa "apri” por consideração, Aury, pelo apoio e incentivo ao mestrado e pela amizade.

À Lucila de Jesus Mello Gonçalves, pelo apoio emocional e dicas valiosas para o mestrado.

Ao meu querido companheiro Paulo de Albuquerque Nogueira Filho, que me acompanhou durante todo o processo. 
VEM,

Que te recebo

Te admito

Te atendo

Te entendo

VEM,

Que te dou crédito

Te escuto

Te abrigo

Te amparo

VEM,

Que te acolherei com dores ou sem dores.

Porque sei que me acolherás quando precisar de ti.

Porque sei que me entenderás quando ocupares em mim o meu lugar

E sentirás comigo a minha dor e minha alegria

De ser humano e trabalhador da vida como

Todos que gostam de viver e do que fazem em vida.

VEM,

Que estou feliz de estar contigo, de ter a chance única de conhecer a tua pessoa.

$V E M$,

Que o hoje pode estar sendo doloroso, Regado a desconforto e maleficência, tristeza e violência,

Mas esse mesmo hoje pode ser por nós transformado

E o amanhã vivido como uma delícia vital.

VEM,

Que alegres tua vida, minha vida, leves e doces

Hão de ser pela nossa determinação.

VEM,

Queremos que seja assim por força da nossa vontade

E nada poderá impedir.

VEM

E verás que, ao nos abraçarmos, vamos compreender Que somos um só, tanto quanto o mundo que habitamos,

Que apesar de todas as nossas diferenças,

Estaremos sendo mais humanos, mais solidários,

Mais saudáveis, mais acolhedores e acolhidos.

O que plantamos?

O que colhemos?

Valeu a pena?

O que nos falta fazer mais?

Ray Lima 
Zakabi D. Aconselhamento pré e pós-teste anti-HIV na atenção básica: a perspectiva dos profissionais de saúde. São Paulo. Dissertação (Mestrado em Ciências). Faculdade de Medicina da Universidade de São Paulo. 2012.

\section{RESUMO}

Desde 1999, o Ministério da Saúde tem incentivado a ampliação da testagem anti-HIV para atenção básica, com a prática do aconselhamento, buscando, assim, efetivar os princípios de integralidade e descentralização do SUS.

Este estudo teve como objetivo compreender a perspectiva dos profissionais de saúde da atenção básica em relação ao pedido e à comunicação do resultado de teste anti-HIV, em duas capitais de regiões brasileiras distintas, que se assemelham pela grande densidade populacional e desigualdade social: São Paulo e Fortaleza.

Foram realizadas 21 entrevistas semiestruturadas com profissionais de saúde e gestores de duas UBS em cada cidade. Em São Paulo, foram realizadas entrevistas com 2 gestores e 9 profissionais de saúde, e em Fortaleza, com 2 gestores e 8 profissionais de saúde. Foi realizada uma análise temática, dialogando com os conceitos de vulnerabilidade, acolhimento, técnica e afetividade.

Foi solicitado o consentimento livre e esclarecido de todos os participantes e suas identidades foram resguardadas. ${ }^{1}$

Os profissionais de saúde relataram não oferecer o teste anti-HIV para a população geral, com a justificativa de evitar estigma e discriminação. A existência de serviços especializados em DST/aids bem estruturados facilita o encaminhamento dos poucos casos de pedido de teste HIV por demanda espontânea do usuário.

Os profissionais de saúde relataram pedir o teste anti-HIV rotineiramente, principalmente quando baseados em protocolos do Ministério da Saúde, relacionados aos programas de tuberculose e pré-natal. Alguns profissionais relataram coagir, em

${ }^{1}$ O projeto foi aprovado pelos Comitês de Ética em Pesquisa da Faculdade de Medicina da Universidade de São Paulo, da Secretaria Municipal da Saúde de São Paulo e pela coordenação do Sistema Municipal de Saúde Escola de Fortaleza. 
graus diversos, as gestantes a realizarem o teste anti-HIV, contrapondo normas do Ministério da Saúde.

A análise das entrevistas sugere uma dificuldade em realizar o aconselhamento propriamente dito, restringindo-se apenas a um pedido de consentimento para a testagem, especialmente nos casos de testagem baseados em protocolo. Esta análise também sugere que há dificuldades em estimular que a testagem se torne uma necessidade de saúde do usuário, pela dificuldade em lidar com aspectos emocionais dos atendimentos, especialmente relacionados com a possibilidade do resultado positivo para HIV. Desta maneira, os profissionais buscam restringir o atendimento ao que eles imaginam ser o aspecto "técnico" do encontro, focando nas intervenções biomédicas e evitando conversar sobre temas relacionados a emoções e sentimentos.

Por outro lado, esta análise indicou maior facilidade de os profissionais oferecerem o teste anti-HIV dirigidamente a alguns grupos, estabelecidos como prioritários: jovens, trabalhadores do sexo, homens homossexuais e pessoas com diagnóstico de DST.

Algumas UBS apresentam programas que incluem grupos de discussão e questionários padrões sobre a sexualidade, que promovem a demanda pelo teste para população geral.

Salientamos a necessidade de haver maior definição sobre o que é comum e o que é específico no trabalho de cada um dos profissionais da equipe, e espaços de supervisão e educação continuada, com a produção de material didático, para aprimorar o pedido e a comunicação de resultado da testagem anti-HIV.

Palavras-chave: HIV; Síndrome de Imunodeficiência Adquirida; aconselhamento; acolhimento; Atenção Primária à Saúde 


\section{Zakabi D. Pre- and posttest counseling for HIV testing in Health Primary Care}

Units: health professionals' point of view. São Paulo. Dissertation (Master Degree in Science). Faculdade de Medicina da Universidade de São Paulo. 2012.

\section{SUMMARY}

Since 1999 Brazilian Ministry of Health has recommended the expansion of HIV testing in Primary Health Care, with the practice of counseling so thus effect the principles of comprehensive care and decentralization.

The objective of the present study was to understand HIV testing and counseling in Primary Health Care, based on the discourses of their professionals, in two different Brazilian cities, which resemble the high population density and social inequality: São Paulo and Fortaleza.

Semi-structured interviews were conducted with 21 health professionals and managers of two Primary Health Care services in each city. In São Paulo, interviews were conducted with 2 managers and 9 health professionals, and in Fortaleza, with 2 managers and 8 health professionals. We conducted a thematic analysis, based on the theoretical framework concepts of vulnerability, embracement and affection.

All participants informed consents were asked and their identities were held. Health professionals reported not offering HIV testing for general population, trying to avoid stigma and discrimination. Well-structured STD/AIDS services facilitate routing rare cases of user-initiated.

Provider-initiated HIV testing is routinely based on Ministry of Health protocols, related to tuberculosis programs and prenatal care. Some professionals reported coercing, to varying degrees, pregnant women to accept HIV testing, in spite of their right to voluntary consent, as recommended by Ministry of Health.

The data analysis suggests a difficulty in performing the counseling itself, restricted only to a standard requirement for consent, especially for protocols based testing.

This analysis also suggests professionals' difficulties for stimulating HIV testing to become a user's health need, because it deals with emotional aspects of 
care, particularly related to the possibility of a positive HIV test. Thus, practitioners try restricting care to what they imagine to be the aspect of "technics", focusing on biomedical interventions and avoiding emotions and feelings.

On the other hand, this analysis indicated professionals are more inclined for prioritizing some groups for HIV testing: young people, sex workers, men they suppose that are gay and people diagnosed with STDs.

Some Primary Health Care Services promoted some HIV testing demand for general population including groups discussions and standard questionnaires about sexuality to women, men and elders.

We recommend a better definition of what is common and what is specific in the work of each team professionals, and more opportunities for professionals' continued education and support, with the production of teaching materials, for improving HIV testing and counseling.

Descriptors: HIV; Acquired Immunodeficiency Syndrome; Counseling; User Embracement; Primary Health Care. 
Esta dissertação ou tese está de acordo com as seguintes normas, em vigor no momento desta publicação:

Referências: adaptado de International Committee of Medical Journals Editors (Vancouver)

Universidade de São Paulo. Faculdade de Medicina. Serviço de Biblioteca e Documentação. Guia de apresentação de dissertações, teses e monografias. Elaborado por Anneliese Carneiro da Cunha, Maria Julia de A. L. Freddi, Maria F. Crestana, Marinalva de Souza Aragão, Suely Campos Cardoso, Valéria Vilhena. 2a ed. São Paulo: Serviço de Biblioteca e Documentação; 2005.

Universidade de São Paulo. Faculdade de Saúde Pública. Cuenca, AMB, Andrade MTD, Noronha DP, Ferraz MLEF. Guia de apresentação de teses. $2^{\mathrm{a}}$ ed. São Paulo: A Biblioteca, 2006.

Abreviaturas dos títulos dos periódicos de acordo com List of Journals Indexed in Index Medicus. 


\section{SIGLAS}

\begin{tabular}{|c|c|}
\hline ANTI-HIV & $\begin{array}{l}\text { Relacionado ao teste que mede o número de anticorpos ao Vírus da } \\
\text { Imunodeficiência Humana }\end{array}$ \\
\hline ACS & Agente comunitário de saúde \\
\hline COAS & Centro de Orientação e Apoio Sorológico \\
\hline COREN-SP & Conselho Regional de Enfermagem de São Paulo \\
\hline CTA & Centro de Testagem e Aconselhamento \\
\hline DST & Doença Sexualmente Transmissível \\
\hline ESF & Estratégia Saúde da Família \\
\hline EUA & Estados Unidos da América \\
\hline HIV & Vírus da Imunodeficiência Humana \\
\hline IBGE & Instituto Brasileiro de Geografia e Estatística \\
\hline NEPAIDS & Núcleo de Estudos de Prevenção da Aids \\
\hline ONG & Organização Não-Governamental \\
\hline ONU & Organização das Nações Unidas \\
\hline $\mathrm{OS}$ & Organização Social, que gerencia algumas UBS em São Paulo \\
\hline PACS & Programa de Agentes Comunitários de Saúde \\
\hline PECAP & $\begin{array}{l}\text { Pesquisa sobre conhecimento, atitudes e práticas na população } \\
\text { brasileira realizada pelo Ministério da Saúde }\end{array}$ \\
\hline PET & Programa de Educação Tutorial \\
\hline PNACS & Programa Nacional de Agentes Comunitários de Saúde \\
\hline PSE & Programa Saúde nas Escolas \\
\hline QUALIS & Projeto Qualidade Integral em Saúde \\
\hline SAE & Serviço de Atendimento Especializado em DST/aids e Hepatites Virais \\
\hline SER & Secretaria Executiva Regional de Fortaleza/ CE \\
\hline SPE & Saúde e Prevenção nas Escolas \\
\hline SUS & Sistema Único de Saúde \\
\hline UBS & Unidade Básica de Saúde \\
\hline
\end{tabular}




\begin{tabular}{|l|l|}
\hline UNGASS & $\begin{array}{l}\text { “Sessão Especial da Assembleia Geral das Nações Unidas”. Em 2001, } \\
\text { foi realizada uma Sessão Especial que teve como tema a aids }{ }^{2} .\end{array}$ \\
\hline USP & Universidade de São Paulo
\end{tabular}

${ }^{2}$ [homepage na internet]. [Acesso em $\left.01 \mathrm{dez} 2011\right]$. Disponível em: http://www.aids.gov.br/pagina/duvidas-frequentes-sobre-ungass 


\section{SUMÁRIO}

APRESENTAÇÃO .................................................................................. 2

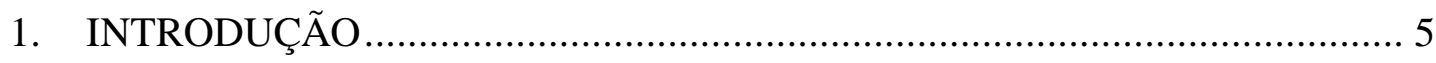

1.1. RESPOSTA À EPIDEMIA DE AIDS: DO CONCEITO DE GRUPO DE RISCO AO DE VULNERABILIDADE ….............................................. 5

1.2. ESTUDOS SOBRE O ACONSELHAMENTO PRÉ E PÓS-TESTE ANTIHIV 12

1.3. ATENÇÃO BÁSICA À SAÚDE ........................................................ 18

1.4. ACOLHIMENTO E AFETIVIDADE ..................................................20

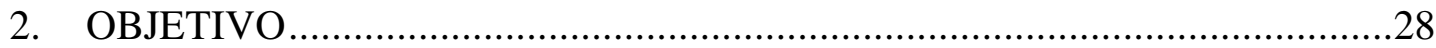

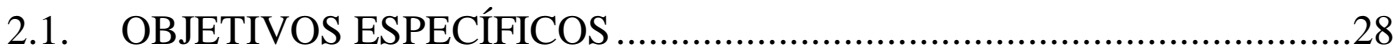

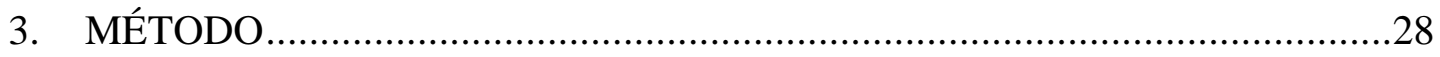

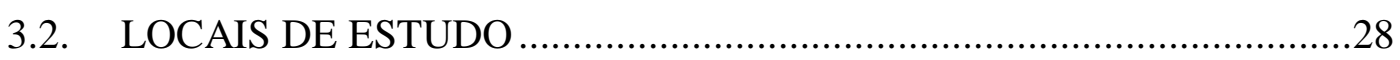

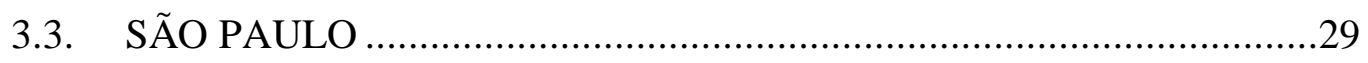

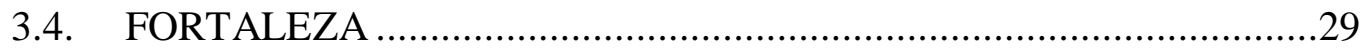

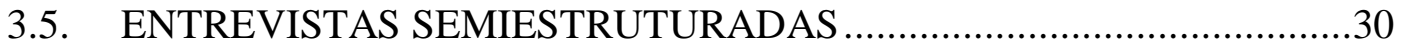

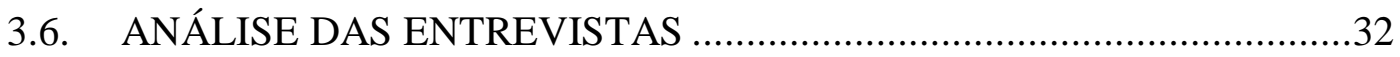

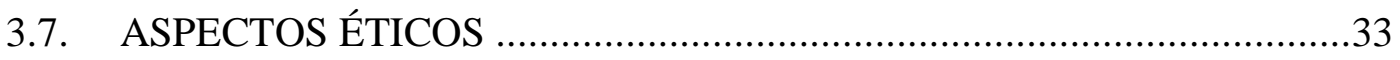

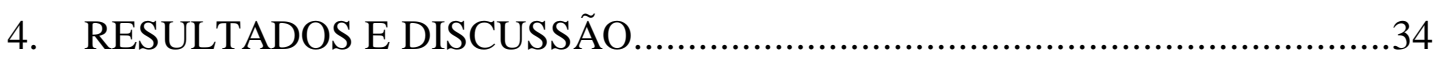

4.1. CONTEXTO DO TRABALHO NA ATENÇÃO BÁSICA ........................35

4.2. RECOMENDAÇÃO DO USO DO PRESERVATIVO ............................41

4.3. OS ENCONTROS SEGUNDO AS PRINCIPAIS SITUAÇÕES DE PEDIDO DO TESTE..........................................................................46

Pedidos de Teste Anti-HIV Baseados em Protocolos dos Programas de PréNatal, Tuberculose e DST

Pedidos de Teste Anti-HIV para População Geral e para "Populações Vulneráveis".

Os Encontros que Favorecem o Pedido do Teste Anti-HIV: Grupos e Atendimentos Clínicos que Abordam a Sexualidade

4.4. OS ENCONTROS PARA A COMUNICAÇÃO DE RESULTADO DE

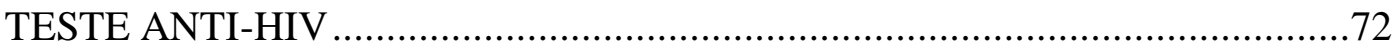

4.5. REFLEXÕES DECORRENTES DA SITUAÇÃO DE ENTREVISTA .....85 


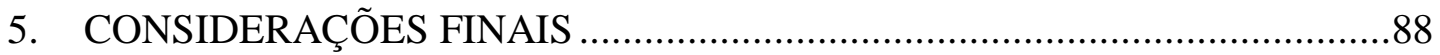

6. REFERÊNCIAS BIBLIOGRÁFICAS.........................................................

ANEXO I - ROTEIRO DE ENTREVISTA COM GERENTES..............................102

ANEXO II - ROTEIRO PARA ENTREVISTAS COM PROFISSIONAIS DE

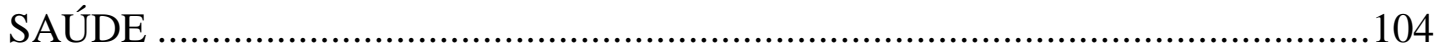

ANEXO III - TERMO DE CONSENTIMENTO LIVRE E ESCLARECIDO PARA GESTOR RESPONSÁVEL PELO SERVIÇO ………………..............................107

ANEXO IV - TERMO DE CONSENTIMENTO LIVRE E ESCLARECIDO PARA PROFISSIONAL DO SERVIÇO .................................................................109

ANEXO V - APROVAÇÃO PELO COMITÊ DE ÉTICA EM PESQUISA DA FACULDADE DE MEDICINA DA UNIVERSIDADE DE SÃO PAULO,

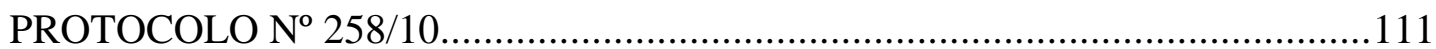

ANEXO VI - APROVAÇÃO PELO COMITÊ DE ÉTICA EM PESQUISA DA SECRETARIA MUNICIPAL DA SAÚDE DA PREFEITURA DA CIDADE DE SÃO PAULO, PARECER N ${ }^{\circ}$ 328/10, CAAE: 0159.0.162.015-1 


\section{APRESENTAÇÃO}

Lembrar dos momentos que me levaram a escrever essa dissertação ajudam a compreender as escolhas pelo tema e a forma como decidimos pesquisá-lo.

Eu me formei como psicóloga na Universidade de São Paulo (USP) em 2004. $\mathrm{Na}$ graduação, encantei-me pela psicologia social, ao ser aluna da $\operatorname{Prof}^{\mathrm{a}} \operatorname{Dr}^{\mathrm{a}}$ Vera Paiva. Durante as aulas, ela exemplificava as teorias com projetos de pesquisa relacionados ao tema do HIV e aids ${ }^{3}$, que participava, através do Nepaids - Núcleo de Estudos de Prevenção da Aids. Animada, eu a procurei para participar de algum desses projetos. Ela me apresentou ao $\operatorname{Prof}^{\circ} \operatorname{Dr}^{\circ}$ José Ricardo Ayres, da Faculdade de Medicina da USP, que coordenava um projeto de prevenção às DST/aids, gravidez não-planejada e uso abusivo de drogas, em uma escola pública de ensino médio, na Região Oeste, em São Paulo. Escrevi uma monografia de iniciação científica dentro deste projeto, uma avaliação sobre a perspectiva dos pais dos alunos desta escola. Assim, desde aquele momento, interessava-me pela perspectiva dos cuidadores.

Com essa experiência, aprendi muito sobre a área da saúde coletiva: conheci o Centro de Saúde Escola Samuel B. Pessoa, seus profissionais e participei de congressos em saúde coletiva. Destaco discussões ocorridas nesses espaços sobre filosofia e educação popular com o $\operatorname{Prof}^{\circ} \operatorname{Dr}^{\circ}$ Ricardo R. Teixeira e sobre violência e gênero com a Prof ${ }^{a}$ Dr $^{a}$ Ana Flávia P. L. d' Oliveira.

Quando me graduei, novamente a $\operatorname{Prof}^{\mathrm{a}} \mathrm{Dr}^{\mathrm{a}}$ Vera Paiva me ajudou a seguir um rumo: indicou-me a participar da organização do campo de parte qualitativa de um projeto sobre órfãos em decorrência da aids, coordenado pelo $\operatorname{Prof}^{\circ} \operatorname{Dr}^{\circ}$ Ivan

\footnotetext{
${ }^{3}$ Neste trabalho, optou-se por usar o termo "Atenção Básica" por ser a linguagem utilizada pelo Ministério da Saúde no momento de escrita deste trabalho. O público principal a que se destina esse estudo são os gestores e os profissionais de saúde que atuam na assistência, que estão familiarizados com suas capacitações e treinamentos com os manuais do Ministério da Saúde. Este estudo visa proporcionar a reflexão sobre suas práticas. A Atenção Básica não é entendida como superficial ou uma assistência com poucos recursos e sim uma parte da assistência que lida com a complexidade do processo saúde-doença, como será detalhado adiante.

Da mesma maneira, escolhemos escrever "aids" em minúsculas, conforme site do Ministério da Saúde. [homepage na internet]. [Acesso em 05 maio 2011]. Disponível em: http://www.aids.gov.br/ Em seus materiais, a forma como foi escrita variou no decorrer dos anos. Inicialmente, referia-se à sigla em inglês, adotada pelo Brasil, "AIDS", para não estigmatizar as pessoas chamadas "Cida", "Síndrome da Imunodeficiência Adquirida". Ao não ser mais considerada uma síndrome, por ter um agente causador definido, os materiais começaram a nomear "Aids", começando por maiúscula. Atualmente, para não destacar a aids em relação a outras doenças, passou a adotar "aids" em seus materiais.
} 
França Junior. Nessa pesquisa, aprendi a realizar entrevistas, transcrições e análise qualitativa.

Após essa experiência, quis me aprimorar e especializar na área de saúde coletiva, pelo Departamento de Medicina Preventiva da Faculdade de Medicina da USP. Nessa especialização, em 2007, passei a conhecer e me interessar pela atenção básica e aprendi sobre observação participante. Realizei uma monografia de conclusão de curso, orientada pelo Prof ${ }^{\circ}$. Dr ${ }^{\circ}$. Ricardo R. Teixeira, sobre um mapeamento dos espaços de comunicação sobre o pedido/resultado de sorologia para o HIV no Centro de Saúde Escola Samuel Barnsley Pessoa, na qual tive importante contribuição para análise sobre gênero da Prof ${ }^{a} \operatorname{Prof}^{a} \operatorname{Dr}^{\mathrm{a}}$ Ana Flávia P. L. d' Oliveira. Em seguida, participei de outra pesquisa sobre os caminhos da integralidade na atenção básica, coordenada pelo $\operatorname{Prof}^{\circ}$ Dr $^{\circ}$ José Ricardo Ayres, no qual realizei observação participante de serviços e entrevistas.

Durante o mestrado, tive o privilégio de acompanhar aulas que ajudaram a escolher os conceitos usados nesta dissertação, com algumas das próprias referências bibliográficas desta trabalho.

Desta forma, esta dissertação é uma continuidade desse processo de aprendizado teórico e de pesquisa, moldado através desses encontros aumentativos de potência.

A seguir apresentarei a forma como escrevemos este trabalho.

No primeiro capítulo, fizemos uma retomada histórica da epidemia de aids, com foco nas mudanças decorrentes na área da prevenção e da assistência, impulsionadas pelos movimentos sociais pelos direitos humanos, especialmente o de homossexuais e de pessoas vivendo com HIV.

Estas mudanças trouxeram novas reflexões teóricas, como a emergência do conceito de vulnerabilidade, desenvolvido no Brasil por Ayres et al. (2003). Ainda, trouxeram a preocupação sobre os momentos do pedido e a comunicação do resultado do teste anti-HIV, com a realização da técnica do aconselhamento. No Brasil, especialmente, há a preocupação em descentralizar o teste para a atenção básica, de forma universal, como será detalhado a seguir. 
Para refletir sobre esses momentos, consideramos interessante trazer os conceitos de acolhimento, desenvolvido por Teixeira (2003a, b) e de afetividade, desenvolvida por Sawaia (2006).

Apresentaremos os resultados e discussão, dialogando com essas linhas teóricas. O objetivo principal deste estudo é analisar os encontros nos quais acontecem o processo de decisão e realização do pedido e a comunicação de resultado de teste anti-HIV pelos profissionais de saúde da atenção básica à saúde.

Por fim, apresentaremos considerações finais, quando destacaremos os principais conhecimentos construídos neste estudo e abriremos pontos para discussão com gestores e profissionais de saúde da atenção básica. 


\section{INTRODUÇÃO}

\subsection{RESPOSTA À EPIDEMIA DE AIDS: DO CONCEITO DE GRUPO DE RISCO AO DE VULNERABILIDADE}

A epidemia de aids é marcada historicamente pela construção social do estigma e da discriminação e sua desconstrução paulatina, principalmente promovida pelos movimentos sociais. Segundo Goffmann, "a sociedade estabelece os meios de categorizar as pessoas e o total de atributos considerados como comuns e naturais para os membros de cada uma dessas categorias.” (2008, p. 11). Ainda segundo este autor (Goffmann, 2008), há três tipos de estigma:

1) As "abominações do corpo" - as "várias deformidades físicas" (p. $12)$

2) As "culpas de caráter individual, percebidas como vontade fraca, paixões tirânicas ou não naturais, crenças falsas e rígidas” (p. 12) e cita como exemplo a homossexualidade e o vício;

3) "Os estigmas tribais de raça, nação e religião, que podem ser transmitidos através de linhagem e contaminar por igual todos os membros de uma família" (p.12).

A história da epidemia de aids se relaciona com os três tipos de estigma, especialmente associado com o segundo tipo, como será detalhado a seguir.

No início da epidemia de aids, de 1981 a 1984, a aids foi associada aos grupos de risco, os chamados $4 \mathrm{H}$ - hemofílicos, homossexuais, usuários de heroína e haitianos. Os primeiros casos foram notificados nos EUA e na França e a identificação desses grupos foi condição necessária para se conhecer a etiologia da doença e norteadora das primeiras ações preventivas. Entretanto, além desta estratégia ser estigmatizante e disseminadora de discriminação contra os pertencentes a esses grupos, criava a impressão, entre as pessoas que não se identificassem com esses grupos, que elas estavam isentas do risco de se infectar. (Ayres et al., 2003)

De 1985 a 1988, foi construído o novo conceito de comportamento de risco, associado às manifestações do movimento gay norte-americano contra a noção de grupo de risco. O movimento homossexual criava e reivindicava estratégias de 
redução de danos, como oficinas de sexo seguro para divulgação do uso do preservativo, testagem dos bancos de sangue e troca de seringas para usuários de droga injetável (Ayres et al., 2003). Estas estratégias trouxeram um avanço na eficácia da redução populacional da infecção, mas, por outro lado, possibilitaram muitas vezes a culpabilização individual e uma análise simplista das possibilidades de se infectar como uma opção e decisão unicamente individual. A discussão pautada nos direitos humanos sobre condições mais gerais que possibilitariam a adoção pelos indivíduos de comportamentos mais saudáveis, foi trazida novamente pela organização coletiva dos homossexuais (Ayres et al., 2003).

Nos anos 90, com o acúmulo de experiências nesse campo, emerge o conceito $^{4}$ de vulnerabilidade, desenvolvido por Mann e colaboradores nos Estados Unidos, e desenvolvido por Ayres et al. (2003), no Brasil. Este conceito busca compreender a prevenção da aids, para além do comportamento individual, considerando os contextos sócio-econômico-político-culturais, que possibilitariam determinado comportamento e suas mudanças. Tais determinantes mais gerais incluiriam os significados da aids, a escolaridade, as relações de gênero, o acesso a recursos e políticas governamentais, entre outros.

A análise de vulnerabilidade envolve a avaliação articulada de três eixos interligados, segundo Ayres et al. (2003):

- Componente individual: diz respeito ao grau e à qualidade da informação de cada indivíduo, a capacidade e possibilidade de entender essa informação, assimilá-la e transformar seu cotidiano a partir dela.

- Componente social: diz respeito ao acesso às informações e relações dos contextos socioculturais nos quais o sujeito está inserido para lidar com essas informações, como as relações de gênero, gerações, raça, classe social, escolarização e rede social, que são marcados pela desigualdade de poder.

\footnotetext{
${ }^{4}$ Há controvérsias se a "vulnerabilidade" é uma "noção" recente a ser desenvolvida para se tornar um conceito ou se já pode ser considerada um "conceito", tema discutido no Seminário 1 - NEPAIDS/PE DST/AIDS 2008 - Fundamentos teórico-conceituais das ações de prevenção às DST/aids no quadro da Vulnerabilidade, dos Direitos Humanos e Emancipação. Neste trabalho, escolheu-se usar “conceito", de acordo com textos de Delor e Hubert (2000) e Ayres et al. (2003).
} 
- Componente programático: refere-se às instituições relacionadas aos sujeitos, ao grau e à qualidade de compromisso, recursos, gerência e monitoramento de programas nacionais, regionais ou locais.

Embora o conceito de vulnerabilidade tenha trazido avanços na área de prevenção à infecção pelo HIV, observamos que há uma dificuldade de sua operacionalização na produção de conhecimento científico e também de sua incorporação nas práticas dos profissionais de saúde, como será discutido nos resultados. Esta questão traz a relevância de relembrar esse histórico da epidemia de aids e ampliar a análise de contextos de vulnerabilidade nas ações relacionadas à prevenção do HIV.

A epidemia do HIV começou a surgir no Brasil no começo dos anos 80, período de redemocratização após o período da ditadura, de 1964 a 1984. O Ministério da Saúde demorou a perceber a gravidade potencial da situação e criar uma resposta, mesmo após casos começarem a ser relatados nos maiores centros urbanos como o Rio de Janeiro e São Paulo. As ações locais nesses centros começaram a acontecer graças à pressão de ativistas e da opinião pública, assustada com a nova epidemia, divulgada pela imprensa. Particularmente em São Paulo, organizações gays realizavam pressão política na Secretaria de Saúde. Paulatinamente, a resposta de São Paulo passou a servir de modelo de esforços similares no país. (Parker, 2003; Teixeira PR, 1997; França, 2008; Paiva, 1992).

O Programa Nacional de Aids foi criado em 1988, no âmbito do Ministério da Saúde, acompanhando o movimento de redemocratização e da reforma sanitária (Galvão, 2002, p. 11). Resultou de um forte movimento social, especialmente da comunidade gay. Este conjunto de forças favoreceu que o Programa construído seguisse os princípios do Sistema Único de Saúde de igualdade e universalidade e dos direitos humanos, o que possibilitou que posteriormente a resposta brasileira se tornasse uma referência internacional (Paiva, 2002; Parker, 2003).

A prática do aconselhamento começou no Brasil a partir dos primeiros casos, através de Organizações Não-Governamentais de militantes gays, que o realizavam para dar suporte, apoio emocional e social, e atividades socioeducativas para as pessoas que realizavam a testagem de HIV. (Pupo, 2007) 
O grupo que inicialmente se organizou, em meados de 1983, dentro da Secretaria de Estado da Saúde de São Paulo, para responder à demanda da comunidade gay, foi a Divisão de Hansenologia e Dermatologia Sanitária, com experiência na luta contra o estigma e discriminação. $O$ grupo procurou o desenvolvimento de estruturas mais efetivas na vigilância epidemiológica, assistência e suporte social para as pessoas infectadas, bem como se relacionar com representantes do movimento gay e da reforma sanitária. (Parker, 2003; Teixeira PR, 1997)

Somente em 1985 o Ministério da Saúde começou a criar um Programa Nacional de Aids, quando já havia Programas Estaduais estabelecidos em 11 dos 27 estados brasileiros, como Ceará, São Paulo e Rio de Janeiro. Os dois últimos se tornaram centros de referência nacional e foi realizado um treinamento para outros estados que começavam um programa para aids. (Parker, 2003; Teixeira PR, 1997)

Em 1988 foi criado o primeiro Centro de Orientação e Apoio Sorológico (COAS), no Rio Grande do Sul, posteriormente chamado de Centro de Testagem e Aconselhamento (CTA). Neste mesmo ano, começou a distribuição de medicamentos para infecções oportunistas pelo sistema público de saúde (Galvão, 2002). Em 1992, foi criado o Projeto Aids I, para o qual houve um forte investimento financeiro do Bando Mundial e do Tesouro Nacional. A ênfase deste primeiro projeto estava na prevenção, seguindo as metas do Banco Mundial no controle da aids. Destaca-se que dos 250 milhões de dólares investidos, 41,08\% eram destinados para prevenção, e dentro desta categoria, 36\% era direcionado para o aconselhamento. (Pupo, 2007; Parker, 2003; Teixeira PR, 1997).

Em1996 foi criada a lei $n^{\circ}$ 9.313, que garantia a distribuição pelo sistema público de saúde de medicamentos para pessoas com HIV e aids. Nesse ano foi iniciada a implementação nacional da distribuição dos antirretrovirais na rede pública de saúde (Galvão, 2002), o que estimulava a realização da testagem, pela possibilidade de tratamento.

No Brasil também ocorreu a associação da possibilidade de se infectar ao pertencimento aos "grupos de risco", pela forma como foram divulgados os primeiros casos de aids pela grande mídia. Foi criado um imaginário popular de que 
a aids estaria associada a pessoas ricas de São Paulo e do Rio de Janeiro, que realizavam viagens internacionais, principalmente homossexuais. Esse imaginário não era questionado nem mesmo pelos especialistas da área médica e autoridades da saúde pública, que se baseavam em informações parciais. Ministros da Saúde descreviam a aids como uma epidemia da elite, que poderia pagar pelo seu próprio tratamento médico. O que se observou, no entanto, na primeira década da epidemia, foi um rápido crescimento da transmissão heterossexual e a pauperização da epidemia (Parker, 1994), sendo o perfil da epidemia atual caracterizado pelos processos de heterossexualização, feminização, interiorização, em direção aos municípios de médio e pequeno porte (Brito et al., 2000).

A estratégia atual do Ministério da Saúde para o enfrentamento da epidemia é a descentralização das suas ações, inclusive a descentralização dos locais de testagem, além dos serviços especializados em DST/aids. Esta estratégia é baseada no desenvolvimento conceitual e mudanças ocorridas no cenário epidemiológico. $\mathrm{O}$ incentivo à testagem para a população geral passa a ser paulatinamente preconizado, partindo do pressuposto de que a aids atinge todos os segmentos da população e não somente os grupos de risco. A testagem é considerada uma ação de prevenção do HIV, pelo maior controle da epidemia pela detecção, prevenção e tratamento de casos, e um direito do cidadão em conhecer sua sorologia e ter acesso ao tratamento. Estudos indicaram que mulheres tendiam a usar mais preservativo após o diagnóstico positivo para HIV, principalmente com parceiros que não vivem com HIV e casuais, como indica análise de entrevistas de Figueiredo (2010) de 183 mulheres que vivem com HIV e de Santos et al. (2002) com 148 mulheres nesta mesma condição.

Desde 1997, o Ministério da Saúde brasileiro recomenda ações programáticas que incluam a testagem de HIV, acompanhadas da prática de aconselhamento pré e pós-teste para gestantes, em "serviços de pré-natal", devido à feminização da epidemia. (Brasil, 1998).

Dessa forma, o Ministério da Saúde busca implementar a integralidade e a descentralização do Sistema Único de Saúde (SUS).

O primeiro documento que encontramos com orientações específicas para a Atenção Básica do Ministério da Saúde foi publicado em 2004, manual 
“Aconselhamento em DST/HIV/Aids para a Atenção Básica” (Brasil, 2004a), como parte da campanha "Fique Sabendo", lançada neste mesmo ano.

O aconselhamento, segundo este manual, é entendido como "um diálogo baseado em uma relação de confiança que visa proporcionar à pessoa condições para que avalie seus próprios riscos, tome decisões e encontre maneiras realistas de enfrentar seus problemas relacionados às DST/HIV/Aids" (Brasil, 2004a, p. 7). O papel do profissional no aconselhamento é: “ouvir as preocupações do indivíduo; propor questões que facilitem a reflexão e a superação de dificuldades; prover informação, apoio emocional e auxiliar na tomada de decisão para adoção de medidas preventivas na busca de uma melhor qualidade de vida.” (Brasil, 2004a, p. 7). Assim, são componentes do processo de aconselhamento: o educativo, através de um diálogo sobre como se infectar e se proteger; o apoio emocional; avaliação de riscos individual e construção de estratégias para diminuir esse risco. $\mathrm{O}$ aconselhamento pode ser realizado individualmente e em grupos e difere da orientação preventiva, porque busca uma avaliação de riscos individuais (Brasil, 2004a). É enfatizada a necessidade do consentimento da pessoa em realizar o teste anti-HIV, compreendendo o significado dos resultados positivo e negativo.

Este manual (Brasil, 2004a) enfatiza a importância do aconselhamento pósteste, no caso de um resultado negativo, para contribuir para elaboração de formas para não se infectar pelo HIV e, no caso de um resultado positivo, para ajudar a lidar com uma potencial transmissão, inclusive a vertical e iniciar brevemente $\mathrm{o}$ tratamento antirretroviral.

Este manual aborda as "principais vulnerabilidades para a infecção do HIV": práticas sexuais sem preservativos, destacando a vulnerabilidade das mulheres, por sua dificuldade em negociar o uso do preservativo com seus parceiros fixos; uso de drogas, pois o consumo de drogas lícitas ou ilícitas "pode alterar a percepção de risco e resultar no relaxamento do uso do preservativo" (Brasil, 2004a, p. 22); outras doenças sexualmente transmissíveis - DST; e jovens, pela "precocidade na iniciação sexual e uso de drogas lícitas ou ilícitas na população brasileira” (Brasil, 2004a, p. 17). 
Por fim, este manual destaca a importância de monitoramento e supervisão para a implantação da prática do aconselhamento.

Encontros periódicos, que permitam reflexão, troca de experiências, problematização das situações e dificuldades encontradas, reorganização interna processual, devem ser viabilizados pelo gestor, pois são importantes para ampliar a resolutividade. (Brasil, 2004a, p. 29)

Nesse mesmo ano, 2004, foi publicado um material sobre implicações éticas do diagnóstico e da triagem sorológica do HIV para diversas situações comuns em UBS, como o pré-natal e casais que queiram saber de sua condição sorológica (Brasil, 2004b).

Especificamente sobre o aconselhamento para as gestantes, o Ministério da Saúde traz uma série de recomendações em outro manual aos profissionais de saúde, que exigiriam uma formação densa em conceitos relacionados à prevenção às DST/aids, como "os conceitos 'vulnerabilidade' e 'situações de risco acrescido"” (Brasil, 2005b, p. 28), as formas de infecção e adoecimento. Ele destaca a oferta do teste anti-HIV de maneira esclarecida e voluntária:

Garantir o caráter confidencial e voluntário do teste anti-HIV. Durante todo esse processo, a gestante deverá ser estimulada a expressar seus sentimentos e dúvidas em relação a essas informações. (Brasil, 2005b, p. 28)

Ainda, este protocolo traz recomendações detalhadas sobre o pós-teste, diferenciando resultados negativos de indeterminados e positivos, enfatizando informações necessárias sobre prevenção às DST/aids e ao tratamento antirretroviral.

Também em 2005 foi produzido um material para capacitação dos profissionais de saúde da rede básica na ação do aconselhamento: "Oficina de Aconselhamento em DST/HIV/ Aids para a Atenção Básica” (Brasil, 2005a).

É importante considerar, na análise dos depoimentos colhidos que realizaremos, que manuais são orientações para a prática, mas transpostas para a assistência e as práticas nas UBS sempre há uma mediação, uma distância, uma mudança de plano que precisa ser considerada. 


\subsection{ESTUDOS SOBRE O ACONSELHAMENTO PRÉ E PÓS-TESTE ANTI-HIV}

Os documentos brasileiros são influenciados por normas internacionais. Destacamos uma revisão de documentos normativos e estudos internacionais relacionados ao aconselhamento para a testagem anti-HIV realizada por Obermeyer e Osborn (2007). A maioria dos estudos descritos por estas autoras se refere às implicações de comunicar e receber um resultado positivo: à comunicação de parceiros; à dificuldade de conseguir e aderir ao tratamento; às relações de estigma e discriminação associados à aids. Poucos estudos discutem implicações de um resultado negativo, como a oportunidade para realizar ações preventivas de HIV. Estes documentos e estudos enfatizam que a testagem anti-HIV seja livremente consentida, perguntando ao paciente se deseja ou não fazer o teste anti-HIV (opt-in testing), ou informando-lhe que será realizado o pedido do teste anti-HIV, como parte de uma rotina de procedimentos, a não ser que eles se recusem (opt-out testing). Também enfatizam as implicações éticas relacionadas às informações e ao cuidado oferecidos durante o pré e o pós-teste anti-HIV.

Estudos internacionais mencionados nesta revisão (id. Ibid.) mostram que a cobertura de testagem anti-HIV é baixa, tanto em países desenvolvidos como em desenvolvimento, e discutem sobre a necessidade de se expandir a testagem anti-HIV para a população geral, ampliar ações de prevenção à infecção pelo HIV e diminuir o estigma. Entretanto, alguns estudos alertam para a necessidade da preocupação coletiva com a epidemia de HIV não sobrepujar os direitos individuais.

O aumento da testagem é influenciado por diversos fatores, como: simplificações da obtenção de consentimento; características dos profissionais de saúde, que incluem gênero, raça/etnia e confiança dos usuários neles; atendimento personalizado, com avaliação de riscos individual; explicações sobre as vantagens e desvantagens da testagem anti-HIV; melhoria dos serviços, como documentado pela África do Sul e pelo Brasil; uso do teste rápido; oferecimento da testagem anti-HIV rotineiramente; horário estendido dos serviços; testagem em locais alternativos aos serviços, inclusive em domicílio (id. Ibid.). 
Obi e Ifebunandu (2006) realizaram entrevistas com 340 pessoas vivendo com HIV, atendidas em duas instituições no sudeste da Nigéria. Este estudo relata a frequente falta de consentimento para realização de pedido de exame anti-HIV e pouco aconselhamento pré-teste em situações consideradas rotineiras na maioria das instituições da Nigéria: pré-natal; antes de cirurgias; e em casais que planejam se casar. Dentre os entrevistados, o consentimento foi pedido somente para aqueles que se apresentaram voluntariamente para testagem de $\operatorname{HIV}(6,2 \%)$ e aqueles que a realizaram para doação de sangue $(13,5 \%)$. A falta de consentimento levava ao choque inicial durante a comunicação de resultado positivo para HIV, o que era amenizado quando o aconselhamento pós-teste era realizado com qualidade.

Estudo realizado nos Estados Unidos (Primary, 2003), no qual foram entrevistados 171 médicos que trabalham na Atenção Básica, obteve como resultado que a maioria (86\%) dos entrevistados não oferecia rotineiramente o teste de HIV aos pacientes sexualmente ativos e a metade não oferecia rotineiramente para as gestantes. Ainda, no mesmo estudo, foram entrevistados 516 residentes em medicina, cuja maioria (81\%), não havia recebido um treinamento formal para aconselhamento e testagem de HIV e considerava que ele deveria fazer parte do currículo escolar $(94 \%)$.

Estudos nacionais (Jordan et al., 2000; Tunala et al., 2000; Landroni, 2004; Moreno, 2006; Fernandes e Britto, 2005) relatam que, para um resultado positivo, o aconselhamento é importante para o seguimento em um serviço especializado em aids e adesão ao tratamento, baseado na atenção, respeito, clareza nas informações e possibilidade de autonomia do paciente. Muitos estudos relatam, no entanto, que nem sempre são oferecidas essas condições propiciadoras de cuidados durante a comunicação do resultado positivo para HIV.

Tunala et al. (2000), em estudo com mulheres que vivem com HIV em São Paulo, discutem sobre a forma como é realizada a comunicação de diagnóstico de HIV positivo. Os autores relatam como aspectos importantes para essa comunicação a relação com os profissionais de saúde, para que as mulheres atendidas lidem com os sentimentos de raiva e tristeza suscitados, consigam cuidar da saúde e tomar a medicação conforme indicado; o entendimento sobre os benefícios da medicação; a confiança depositada nos profissionais e a atenção dada por estes. 
Landroni, em estudo no qual entrevistou 14 mulheres que receberam o diagnóstico de HIV positivo, relata que "o acolhimento inicial parece ter sido decisivo para que procurassem o serviço especializado no atendimento a portadores de HIV/aids" (2004, p. 51) e que "ele também foi importante para a continuidade do acompanhamento especializado" (2004, p. 52). Destaca em sua revisão bibliográfica que o aconselhamento não era realizado, em grande parte, entre pacientes que haviam realizado o exame em hemocentros, em laboratórios privados e em situação de pré-natal em maternidade.

Mencarelli e Vaisberg (2007), baseadas na teoria do psicanalista Winnicott, relatam a experiência de uma delas, psicóloga em serviço especializado em DST/aids, que acompanhou a comunicação de um resultado positivo para HIV, que despertou sua compaixão. O paciente era um jovem que vivia em situação social precária que reunia pobreza e vitimização de violência sexual na infância, forma como ele se infectou pelo HIV. Esta comunicação de resultado positivo para HIV gerou grande sofrimento contratransferencial na analista. Estas autoras afirmam que este sentimento de compaixão, assim como outros afetos, quando reconhecidos pelo analista, podem contribuir para que ele permaneça como presença una e real no encontro clínico.

Moreno (2006), ao entrevistar 14 homens após o aconselhamento pós-teste no Centro de Testagem e Aconselhamento, que receberam resultado positivo no teste anti-HIV, observou que o encaminhamento para serviços especializados para tratamento poderia gerar ansiedade por ser um local desconhecido. Ainda, a mesma autora considera, baseada na teoria do mesmo autor, Winnicott, que no processo de revelação do diagnóstico de infecção pelo HIV, mais importante do que os procedimentos e informações em si, era "o setting criado que se inicia desde o momento em que o cliente telefona para marcar o horário de aconselhamento" (2006, p. 124), a forma como é dada a comunicação e a disponibilidade ao encontro do profissional de saúde.

Esta autora, em trabalho anterior, escrito com Reis (Moreno e Reis, 2002), sobre a comunicação de resultado de HIV, considera que o aconselhamento deve ser transformado em um 
responsável pela comunicação, sob essa ótica, torna-se presença plena de significado, dando-lhe sustentação, apoio, confiança, e possibilitando a manutenção e/ou restituição da saúde (Moreno e Reis, 2002, p. 24)

Estes autores (Moreno e Reis, 2002) não afirmam que esta capacidade seja exclusiva dos psicanalistas, porém a teoria winnicottiana pode ser norteadora para ações acolhedoras dos profissionais de saúde.

Pupo (2007), em análise hermenêutica de documentos brasileiros e internacionais relacionados ao aconselhamento em DST/aids, estudos avaliativos e teorias relacionadas, relata a dificuldade de articular a ideia do aconselhamento teórica e normativa para o campo das práticas de saúde, de maneira exitosa e consistente. Entre os motivos apresentados pela autora, destaca-se para este trabalho a falta de aprofundamento teórico dos próprios documentos relacionadas à proposta do aconselhamento no campo da aids e à falta de formação dos profissionais. A autora analisa ambiguidades nos manuais nacionais e internacionais sobre aconselhamento: misturam metas e preocupações comprometidas com o plano individual, mais abertas e focadas na singularidade do usuário; e metas coletivas e sociais, mais diretivas e fechadas, focadas em políticas públicas determinadas e da saúde coletiva em geral. Analisa que o aconselhamento é, originalmente, uma prática individual, com o objetivo de contribuir para que o indivíduo compreenda a si mesmo, reflita sobre seus recursos e limitações e possa tomar livremente decisões pessoais. Considera que ações que visem promover e incentivar determinados comportamentos pré-fixados poderiam ser mais adequadas se exercidas em outras práticas que não o aconselhamento, como técnicas grupais ou ações educativas. Entre estas técnicas grupais e ações educativas, salienta as campanhas educativas de massa e trabalhos educativos com grupos, visando: fornecer informações sobre as tendências da epidemia; comportamentos e situações de risco, inclusive informações gerais sobre uso do preservativo; divulgação de serviços; ou o incentivo para engajamento em uma causa ou em uma ação social. A autora ressalva que a ação de aconselhamento não deve ser isolada e sim inserida dentro de uma estratégia mais ampla de prevenção e assistência. Por fim, esta autora (Pupo, 2007) e Paiva et al. (2006) criticam abordagens que se focam no autoconhecimento dos sujeitos e não abordam a esfera dos direitos, a responsabilidade não somente por si, mas também pelos outros, em um exercício de cidadania. 
Paiva et al. (2006) analisaram aspectos da resposta brasileira à aids, entre os quais destacamos a oferta de teste anti-HIV e aconselhamento em relação às metas da UNGASS. A UNGASS é uma Declaração de Compromisso sobre HIV/aids, realizada pela Organização das Nações Unidas (ONU), em 2001, que tem como referência as abordagens que relacionam saúde e direitos humanos. Esse compromisso estabeleceu indicadores e metas a serem monitorados pelos países signatários. Os autores analisaram documentos de gestão do Programa Nacional DST/Aids do Ministério da Saúde (PN-DST/Aids), informações disponibilizadas por membros da equipe técnica ou consultadas no site desta instituição. Esses autores observaram que a população mais citada na alocação de recursos foi a de adolescentes escolarizados. Consideram que o percentual de pessoas testadas cresceu de $20 \%$ em 1998 para 32,9\% em 2005, principalmente entre as mulheres de 25 a 39 anos. Paiva et al. (2006) associam esse aumento à incorporação do teste anti-HIV na rotina do pré-natal. Estes dados, segundo os autores, sugerem que os homens e as mulheres não gestantes provavelmente não têm se beneficiado dessa política. Observam desigualdades segundo nível de escolaridade, regionais e raciais. Os dados de 2005 descrevem que os homens negros são os menos testados, 22\% em 1998 e $26 \%$ em 2005.

Um relatório de 2004, elaborado pelo Ministério da Saúde (Szwarcwald e Souza Junior, 2006), estima, por processo de amostragem, a estimativa da proporção de gestantes infectadas pelo HIV no Brasil. Durante a internação para o parto era pedido para gestante preencher, por meio de entrevista, uma cartilha informando se houve pedido de teste de HIV e se a parturiente conhecia o resultado do mesmo, totalizando cerca de 19.800 parturientes no Brasil. No Brasil, a cobertura efetiva do teste de HIV durante o pré-natal foi estimada em 52\%. Entre as gestantes que tiveram pedido de teste de HIV, 88\% tiveram conhecimento do resultado antes do parto. Em locais onde as medidas profiláticas preconizadas pelo Ministério da Saúde foram implantadas na rotina do pré-natal, as taxas de transmissão vertical foram reduzidas a menos de $2 \%$.

Um estudo realizado em Fortaleza descreve como tem sido realizado o aconselhamento para a testagem anti-HIV para gestantes no cotidiano dos serviços da rede básica (Araújo et al. 2006). As autoras analisaram o aconselhamento pós-teste 
anti-HIV em três Unidades Básicas de Saúde da Família de Fortaleza, localizadas na região administrativa da Secretaria Executiva Regional IV (SER IV). O município de Fortaleza é dividido em seis Secretarias Executivas Regionais. As pesquisadoras observaram o atendimento de 12 enfermeiros em consultas de pré-natal. As autoras não mencionam quantas eram enfermeiras, porém se imagina que eram maioria, porque em alguns momentos do texto referem-se pelo artigo feminino "as enfermeiras". As salas, nas quais o aconselhamento acontecia, eram separadas por divisórias que permitiam que pessoas fora da sala escutassem o que era conversado e nelas ocorriam constantes interferências de outros profissionais ou por pacientes, o que atrapalhava a privacidade e concentração dos sujeitos. As consultas eram rápidas, segundo as autoras, devido à grande demanda de atendimentos e exigência de produtividade, o que impossibilitava o aprofundamento de conversas. As pacientes demonstravam preocupação pelo resultado do teste anti-HIV, porém, o foco dos atendimentos eram questões clínicas relacionadas à gestação, o que faz pressupor, embora não mencionado pelas autoras, que todos os atendimentos observados foram de resultado negativo para o HIV. Os profissionais passavam um grande número de procedimentos normativos que deveriam ser adotados pelas gestantes e não tinham interesse por seu contexto de vida, nem as deixavam à vontade para tirar suas dúvidas. Além disso, usavam termos técnicos, de difícil entendimento. Assim, os atendimentos privilegiavam a quantidade de pessoas atendidas, em detrimento da qualidade e era centrada na atenção curativa.

Estudo de avaliação da implantação de ações de prevenção das DST/aids numa Unidade de Saúde da Família em São Paulo, comparando o perfil tecnológico da Unidade de Saúde da Família com as tradicionais Unidades Básicas de Saúde (Ferraz, 2008; Ferraz e Nemes, 2009), considerou que elas não se diferenciavam: o cuidado médico individual centraliza e determina o trabalho e a prevenção às DST/aids reduzem-se a orientações prescritivas. Destaca que a única ação criada após a implantação da Saúde da Família na unidade estudada voltada para esse fim é a testagem para HIV, sífilis e hepatites. Sobre o aconselhamento durante o pré e pósteste anti-HIV, especificamente, observou que o responsável exclusivo por essa ação era o enfermeiro, com supervisões periódicas unicamente para ele e um protocolo de referência. O aconselhamento observado se reduzia ao preenchimento deste 
protocolo e à prescrição de condutas. Este protocolo era um formulário padronizado pela Coordenação Municipal, para a qual deveria ser enviado após preenchido. Nele constavam informações pessoais do usuário, suas práticas sexuais e de uso de droga, sua motivação para testagem e outras informações relacionadas a riscos de infecção. Para as gestantes, não era prevista a realização de aconselhamento pré e pós-teste, segundo entrevista com o enfermeiro e observado nas consultas. Nunca havia sido diagnosticado um resultado positivo para o HIV. Se isso acontecesse, o resultado seria entregue no serviço especializado e o enfermeiro marcaria consulta neste, lugar associado por este como "suporte" para os usuários, pela presença de psicólogos. As autoras sugerem que sejam criados referenciais próprios para a Estratégia Saúde da Família, para que se efetive como modelo assistencial e transforme as práticas de atenção à saúde, voltando-se para práticas preventivas de doenças e de promoção da saúde, através do trabalho multiprofissional e interdisciplinar, indo além do modelo biomédico, que hierarquiza a atuação de cada agente no processo de trabalho e fortalece a medicalização. Salienta a necessidade de maiores investimentos dos órgãos gestores na definição tecnológica dessas ações e no processo de implantação.

\subsection{ATENÇÃO BÁSICA À SAÚDE}

A atenção básica à saúde tem sido identificada pela Organização Mundial de Saúde como uma importante estratégia para extensão de cobertura e aumento da resolutividade dos serviços de saúde, desde a segunda metade dos anos 70, a partir das resoluções da Conferência de Alma-Ata, de 1978, reiteradas, no Brasil, na $7^{\text {a }}$ Conferência Nacional de Saúde. (Schraiber e Mendes-Gonçalves, 1996)

A unidade básica de saúde é a porta de entrada para os serviços e pode desenvolver uma assistência integral e ao mesmo tempo inovadora e tecnologicamente ultramoderna, "por propiciar espaços para a emergência de novas questões assistenciais relacionadas a necessidades não 'trabalhadas' do ponto de vista técnico". (Schraiber e Mendes-Gonçalves, 1996, p. 34)

As situações assistenciais da atenção primária quase sempre podem ser conceituadas como casos epidemiologicamente complexos. Esta é uma complexidade que se transfere para o trabalho profissional, mesmo que, 
enquanto situação clínica, seja uma patologia simples. (...) A atenção primária, ao ser um primeiro atendimento, servirá obrigatoriamente de porta de entrada para o sistema de assistência. Ao mesmo tempo, porém, constitui, no sistema, um nível próprio de atendimento e deve ir resolvendo uma dada gama de necessidades que extrapolam a esfera da intervenção curativa individual. (Schraiber e Mendes-Gonçalves, 1996, p. 35)

A importância da Atenção Básica à Saúde também se dá pela "extensão e capilaridade da rede de serviços (...), que não encontra paralelo em nenhum outro equipamento da rede de serviços de saúde" (Teixeira RR, 2005, p. 592).

Segundo Starfield (1994), as seguintes características devem estar presentes e serem avaliadas na Atenção Básica, a longitudinalidade, entendida como a continuidade no tempo dos encontros e nas formas de cuidado entre profissional de saúde e usuário; a compreensão das necessidades, através do seu reconhecimento e oferecimento de ampla gama de serviços; e uma coordenação do cuidado, através da organização de um sistema de informação, no qual este seja rapidamente reconhecida e trazida para o cuidado do usuário.

Atualmente, a reorganização da atenção básica está pautada na Estratégia Saúde da Família, segundo a portaria no 648, de 28 de março de 2006 (Brasil, 2006). A Estratégia Saúde da Família foi implementada em 1994 e visa reorientar o modelo assistencial com a aproximação de profissionais de saúde com a comunidade, através de equipes interdisciplinares, as quais incluem agentes comunitários de saúde, e realização de visitas domiciliares.

Como mencionado anteriormente, a estratégia atual do Ministério da Saúde para controle da epidemia de aids é a descentralização de testagem anti-HIV dos serviços especializados para a atenção básica.

As Unidades Básicas à Saúde (UBS) podem oferecer a primeira oportunidade para se realizar o diagnóstico de HIV em pessoas assintomáticas ou que já apresentem sintomas e podem reduzir a transmissão vertical através do oferecimento da testagem a todas as gestantes. Diferentemente de um serviço especializado em DST/aids, os profissionais da atenção primária atendem a diversas demandas da população e devem cumprir diferentes protocolos. A oferta do teste anti-HIV pode surgir de uma demanda individual ou de uma demanda epidemiológico-sanitária. 
O pedido pela testagem pode ser uma demanda espontânea do usuário, um oferecimento a partir de um protocolo seguido pelo profissional de saúde nas rotinas programáticas da atenção primária, como pré-natal e tuberculose, ou uma necessidade percebida a partir de uma conversa entre ambos os sujeitos.

Através da ação das visitas domiciliares, especialmente nas unidades com Estratégia Saúde da Família, as conversas individuais e em grupo que gerem a demanda pelo teste anti-HIV podem ser ampliadas para além dos espaços físicos das unidades de saúde. Entretanto, é necessário observar, do ponto de vista técnico e ético, que a decisão em fazer ou recusar a testagem de HIV deve ser resultado de um encontro, ou seja, é necessário informar o paciente sobre a finalidade e dificuldades da testagem e pedir seu consentimento. Mesmo pedidos rotineiros, previstos em protocolos, precisam desta conversa e do aceite do sujeito envolvido. A exposição e discussão sobre as necessidades, finalidades e dificuldades da testagem por parte dos profissionais de saúde são recomendadas e caracterizam a chamada prática de “aconselhamento", como indicado pelo Ministério da Saúde.

\subsection{ACOLHIMENTO E AFETIVIDADE}

Nos últimos anos, ocorre um movimento pela humanização na produção de cuidados primários de saúde e ganha importância a temática do acolhimento e a discussão a respeito do acesso nos serviços de saúde (Teixeira RR, 2003b).

Segundo formulação de Ricardo Rodrigues Teixeira, a partir de qualquer encontro entre profissional de saúde e usuário numa UBS, ocorrem conversas, nas quais as pessoas se afetam e podem ser formados vínculos. O acolhimento é uma particular técnica de conversa, a partir da qual o usuário pode ser atendido em sua demanda e ampliar seu trânsito em uma rede de conversações, que se expande para todo o serviço e seus encontros.

Trata-se rigorosamente de uma técnica de conversa, um diálogo orientado pela busca de uma maior 'ciência' das necessidades de que o usuário se faz portador, e das possibilidades e dos modos de satisfazê-las (Teixeira RR, 2003a, p. 284). 
A prática do acolhimento não é restrita a algum espaço formal, a investigação/ elaboração/ negociação das necessidades que podem vir a ser satisfeitas nunca cessa efetivamente. Assim, Teixeira (2003a, b) diferencia o conceito de "acolhimento" do que usualmente se nomeia como "acolhimento" nos serviços de atenção básica, uma atividade particularizada, geralmente o acesso, porta-de-entrada ou algum pronto-atendimento, embora esta técnica esteja presente também nesses espaços, por exemplo, ao se investigar as demandas iniciais de um paciente, perguntando-se seus motivos e razões para a busca do serviço. Não existe uma "fórmula" de como fazer o acolhimento, ele se define em ato, o que é importante é estar claro o quê fazer e para quê. ${ }^{5}$

Teixeira RR (2003a) afirma que a satisfação de necessidades de saúde é a teleologia e a substância moral das práticas de saúde. O usuário de seus meios técnicos é sempre o paciente, mediado pelo médico. Assim, o paciente participa deste uso, porém de modo assimétrico em relação ao profissional. Os profissionais de saúde são formados e instruídos para um tipo específico de conversa, guiada particularmente pela anamnese médica. $\mathrm{O}$ acolhimento e as técnicas como as de aconselhamento podem romper este padrão de conversa e permitir a expressão de novas necessidades e afetos.

A técnica é apresentada no estudo deste autor (Teixeira RR, 2003a) como uma mediação da experiência humana, na qual há apropriações subjetivas nos encontros, que visam determinado fim. No caso do encontro entre profissional de saúde e usuário, satisfazer as necessidades de saúde deste último.

Segundo este autor, o profissional, numa escuta atenta às suas necessidades de saúde, pode oferecer determinados serviços para satisfazê-las ou mesmo oferecer outras respostas e reconhecer novas necessidades, favorecendo com que o usuário se mova pelos espaços da rede de conversações de que é composta. Nesse trabalho, especificamente, compreenderemos cada encontro entre profissional de saúde e usuário dentro de um serviço de atenção básica como parte de uma rede de conversações.

\footnotetext{
${ }^{5}$ Teixeira RR. Exposição no Encontro Temático: A Clínica Ampliada e o Acolhimento nos Serviços de Saúde no SUS. São Paulo. 2010.
} 
O modo como esse usuário é recebido no serviço é primordial para “investigação/elaboração/negociação das necessidades que podem vir a ser satisfeitas" (Teixeira RR, 2003a, p. 259).

O usuário, ao procurar um serviço de saúde de atenção básica, espera que suas necessidades de saúde sejam atendidas de acordo com os recursos presentes e conhecidos por ele. Em seu percurso dentro do serviço, tem encontros com outros usuários e profissionais de saúde, nos quais as necessidades de saúde podem mudar, emergir e transparecer, pois nem sempre são claras desde o princípio para o próprio sujeito. Como as necessidades são geradas relativamente à sua potencialidade de satisfação, novas ofertas podem fazer emergir "novas" necessidades.

A prática do acolhimento não é restrita a algum espaço formal, a investigação/ elaboração/ negociação das necessidades que podem vir a ser satisfeitas nunca cessa efetivamente. No entanto, a realização do acolhimento nestes termos não depende somente de características individuais dos profissionais, mas também de condições que possibilitem esta prática. Trazer esta questão como um imperativo moral ou individualizá-la como uma questão do caráter do profissional pode levar ao adoecimento dos profissionais, que podem se sentir frustrados e impotentes por não encontrarem condições para implantar a prática do acolhimento. Quando a equipe do serviço assume o desafio de implantar a técnica do acolhimento no cotidiano de suas práticas, é obrigada a colocar em análise o processo de trabalho, a organização institucional e a divisão de poder, relacionada aos papéis e à relação entre gestor e trabalhadores.

Entendemos a prática de aconselhamento como um tipo especial de acolhimento, no qual a oferta da testagem de HIV pode emergir como necessidade de saúde para o usuário ou ampliar a compreensão que ele já tem desta necessidade. $\mathrm{O}$ acolhimento, segundo Teixeira (2003), é uma técnica de conversa, um diálogo que visa à identificação e compreensão das necessidades do usuário, com a elaboração e negociação dos modos de satisfazê-las, ampliando seu trânsito em uma rede de conversações. Não se trata, pois, de uma conversa pessoal que se faria pela amizade ou simpatia pessoal ao caso. Propomos que o aconselhamento seja entendido como uma tecnologia, isto é, "uma aproximação transformadora de seu objeto de 
intervenção na direção de determinada finalidade que esta ação pretende alcançar" (D’Oliveira et al., 2009).

Schraiber (2008) analisa a prática médica como técnica que possui um caráter social e deve ser universalizada, "um procedimento dotado de um saber que o dirige e padroniza" (p. 212), e que tem uma dimensão singular em cada ato, uma "técnica mais criativa, que permite ao agente inovar" (p. 212). Nesse sentido, analisa a prática médica como possuindo duas dimensões indissociáveis: a "técnica-tecnológica" e a "técnica-arte". A autora relaciona a "técnica-tecnológica" à "aplicação científica dotada de razoável repetitividade e mecanização" (p. 215), característica acentuada pelo surgimento de instrumentos e aparelhos diversos. Já a "técnica-arte" envolve a criação e a inovação presentes para lidar com a singularidade de cada caso e na qual se inscreve a autonomia decisória do médico. A arte se refere, segundo a autora, à dimensão mais subjetiva da prática, relacionada à "experiência clínica pessoal do médico" (p. 213).

Para enriquecer o debate sobre a prática dos profissionais de saúde, traremos, como contribuição, o conceito de "afetividade", conforme definido por Sawaia (2003, 2006), o qual relacionaremos ao aspecto "técnica- arte" presente na técnica médica apresentada por Schraiber. Embora a análise de Schraiber tenha se voltado ao trabalho médico, com a especificidade da autonomia na decisão assistencial deste, consideramos que a prática do enfermeiro, de interesse particular deste trabalho, também se reveste de uma cientificidade a que se remete ao aspecto "técnicotecnológico" e também exige uma certa flexibilidade e adequação destes aspectos no encontro com o paciente singular. Schraiber (2008) enfatiza o aspecto ético das relações intersubjetivas e a responsabilidade com o outro, já Sawaia (2009), enfatiza o aspecto afetivo relacionado com a ética nas relações.

Historicamente, os afetos têm sido menosprezados pela ciência, que busca uma suposta "neutralidade" e "objetividade". Segundo Barreto (2006), "desde os gregos, as emoções são consideradas paixões que perturbam a alma e apontadas como aquilo que nos impede de pensar, sendo necessário, portanto, domá-las através da razão.” (p. 57) Barreto (2006), juntamente com Sawaia, enfatizam a importância da afetividade para se refletir sobre a saúde. 
Os afetos são apresentados por Sawaia como sentimento e emoção, baseada em Espinosa e Vygotsky:

1. Sentimento: reações moderadas de prazer e desprazer, que não se refere a objetos específicos.

2. Emoção: fenômeno afetivo intenso, breve e centrado em fenômenos que interrompem o fluxo normal da conduta. (Sawaia, 2006, p. 98)

Os afetos estão ligados à ética, porque podem aumentar ou diminuir a possibilidade de ação para as pessoas buscarem, de maneira autônoma, a liberdade e a felicidade. Eles são gerados nos encontros. É impulsionado pelos afetos que decidimos se algo é bom e se algo deve ser evitado. Uma ideia ou uma ação mudam apenas com uma emoção mais forte. Como os afetos são gerados nos encontros com o outro, o caminho da recuperação da afetividade está na coletividade. Quando as pessoas se relacionam pelo medo e pela recompensa, são servis, contrariamente aos laços de amizade, formados por pessoas livres. Pelo medo, as pessoas podem aceitar a humilhação como natural e se deixarem usar como instrumento. (Sawaia 2003, 2006)

Sawaia (2006) destaca que estes afetos são sentidos pelo sujeito e têm sua gênese em "intersubjetividades delineadas socialmente" (Sawaia, 2006, p. 98). Os afetos são constituídos em um processo sócio-histórico. Destaca o sofrimento, especialmente nas situações da dialética inclusãol exclusão, nomeando-o como sofrimento ético-político, para destacar que se originam de ações éticas e políticas sociais. Acrescentamos que o sofrimento ético-político se relaciona com contextos de vulnerabilidades, que diminuem a potência dos sujeitos para perseverarem em sua existência. $\mathrm{O}$ aumento da potência se relaciona com a capacidade de ser afetado pelo outro e se abrir para bons e maus encontros (Cintra e Sawaia, 2000), relacionados às emoções alegres e tristes. Já a diminuição de potência se relaciona ao sofrimento ético-político, que leva a uma imobilização dessa capacidade de se afetar pelos outros.

[O sofrimento ético-político] revela a tonalidade ética da vivência cotidiana da desigualdade social, da negação imposta socialmente às possibilidades da maioria apropriar-se da produção material, cultural e social de sua época, de se movimentar no espaço público e de expressar desejo e afeto. (Sawaia, 2006, p. 104) 
Sawaia e Barreto conceitualizam a saúde como potência de ação: "tudo o que aumenta o único fundamento da virtude, que é a capacidade de agir em prol da manutenção do próprio ser" (Barreto, 2006, p. 13).

$\mathrm{Na}$ escuta às necessidades, o profissional e o usuário se afetam, de maneira que possam aumentar ou diminuir sua potência para perseverar em sua existência, ao sentirem-se alegres ou tristes. O cuidar do outro implica em certo distanciamento, caso contrário, sufoca. Por exemplo, quando há uma identificação intensa entre o cuidador e aquele que é cuidado, por motivos diversos, mas sempre de ordem inconsciente, a dimensão singular daquele que é cuidado e de suas potencialidades são desvalorizadas, aparecendo somente o cuidador como protagonista do processo de cuidar.

As situações nos serviços públicos de saúde refletem as condições de desigualdade da sociedade na qual pertencem. Isso pode ser visto mais diretamente nos encontros entre profissionais de saúde e usuários e nas possibilidades de negociação e diálogo ao lidar com suas necessidades de saúde.

As ações dos profissionais de saúde, durante o encontro com os usuários, são perpassadas pelos discursos técnicos-científicos de suas formações, seus valores e crenças relacionados com as condições políticas e estruturais nas quais ocorram estes encontros.

Pensamos que os bons encontros, que favorecem a saúde, tanto de usuários, como de profissionais de saúde, dependem da possibilidade de autonomia dos usuários e dos profissionais em tomar decisões.

O discurso técnico-científico de prevenção às DST/aids se baseia geralmente em afetos tristes, como medo, culpa e desconfiança. Como reflete Schraiber (2008) sobre os valores éticos presentes nas opções assistenciais, que reiteram ou se opõe a formações culturais:

o uso de preservativos, a circulação de informações, a aceitação de situação de risco, etc. mostram que a proposição preventiva implica restrições ou sofrimentos individuais, em respeito à liberdade e ao prazer de outros - e não aos próprios. (p. 225)

Movimentos sociais e pesquisadores de universidades têm se lançado ao desafio de associar afetos alegres a práticas preventivas, como amor, sexualidade, 
confiança, intimidade e solidariedade, como o debate promovido sobre a "prevenção posithiva", pela ONG Abia (Raxach et al., 2009) e a publicação do livro "Fazendo arte com camisinha", de Vera Paiva (2000).

Compreendemos que os afetos emergentes de cada encontro são também socialmente construídos e representam a circulação de ideias e concepções dos contextos socioculturais nos quais eles ocorrem.

Por um lado, o serviço tem o compromisso técnico-politico de enfrentar a epidemia de aids, por outro, cada sujeito traz questões de sua vida cotidiana e interesses individuais. Como os interesses particulares de cada sujeito podem se integrar com a preocupação coletiva em se conter/diminuir a epidemia de HIV/aids?

Segundo Schraiber (1997), as ações de saúde são consideradas difíceis por necessitarem conciliar a sabedoria técnica-científica e os valores nos quais nos socializamos. Um ponto de partida de solução para esses conflitos morais é a retomada da ética profissional. A resolução desses conflitos apenas cabe no contexto prático, como por exemplo, a partir do diálogo entre pares e outros profissionais, para trocas de experiências. A autora enfatiza a necessidade da retomada de éticas interativas e comunicacionais nas relações intersubjetivas entre médico e paciente e o estímulo à emancipação.

Consideramos que a melhores posturas éticas podem ser retomada quando são elaborados nos profissionais os discursos sociais e técnico-científicos que perpassam suas práticas, e os afetos emergentes, relacionados ao estigma e à discriminação construídos ao longo da epidemia de aids, podem ser desconstruídos. Segundo Goffmann, "a sociedade estabelece os meios de categorizar as pessoas e o total de atributos considerados como comuns e naturais para os membros de cada uma dessas categorias." (2008, p. 11).

Sawaia (2009) considera que a ética se relaciona com os afetos, entendidos como afetações: a capacidade para lidar com situações-limite e construir superações conjuntas é conseguida a partir de "bons" encontros, que componham com sua potência para se conservar.

A consciência/sentimento de que nossa potência de passar da passividade à atividade só é possível por meio do outro nos torna comprometidos socialmente, não por obrigação, mas como ontologia. 
E são os afetos os responsáveis pela união dos esforços (conatus), em nos fazermos um, como se fôssemos uma única mente e um único corpo. (Sawaia, 2009, p.370)

O conceito de potência se diferencia da noção mais tradicionalmente norteamericana de "empowerment", com foco no indivíduo, pois este, segundo crítica de Paiva (2000) e Santos (2004), pressupõe que alguém vai capacitar ou atribuir poder, levando a consciência à outra pessoa. Como a potência de ação de cada sujeito é dependente de bons encontros, as possibilidades de felicidades individuais estão intrinsecamente ligadas com as coletivas: somente posso ser feliz, quando encontro outras pessoas felizes, ou como diz o poeta Ray Lima, "cuidar do outro é cuidar de mim" (Lima, 2010).

Neste trabalho, estudaremos como tem acontecido a descentralização da testagem anti-HIV e do aconselhamento pré e pós-testagem dos serviços especializados para a rede básica, em termos da qualidade dos encontros, da perspectiva técnica e ético-política. 


\section{OBJETIVO}

Compreender a perspectiva dos profissionais da atenção básica à saúde sobre como são realizados os encontros e conversas com os usuários, nos quais emerge o pedido de testagem anti-HIV, e como tem se dado a comunicação deste resultado.

\subsection{OBJETIVOS ESPECÍFICOS}

A partir da perspectiva dos profissionais de saúde:

- Descrever o que os profissionais consideram como facilidades e dificuldades para o trabalho em saúde de maneira geral, que repercutem no pedido e comunicação do resultado do teste anti-HIV;

- Descrever de quem parte a iniciativa para a testagem e analisar como e por que isto acontece;

- Descrever e analisar quais são os assuntos priorizados durante o pedido e a comunicação do resultado do teste anti-HIV;

- Descrever e analisar quais são os afetos emergentes durante esses encontros e como os profissionais lidam com eles.

\section{MÉTODO}

\subsection{LOCAIS DE ESTUDO}

Consideramos relevante estudar a situação de pedido e comunicação de resultado do teste anti-HIV em duas capitais brasileiras, de regiões socioculturais distintas, ambas com alta densidade populacional e desigualdade social: São Paulo e Fortaleza. 
Foram pesquisados dois serviços de atenção básica em cada uma dessas capitais, com diferentes estruturas, por critérios relacionados a disponibilidade dos serviços e viabilidade de pesquisa.

\subsection{SÃO PAULO}

Escolhemos o distrito do Butantã, na região centro-oeste de São Paulo como local deste estudo. Nesta região, há um serviço especializado em DST/aids, um SAE - Serviços de Assistência Especializada (Prefeitura de São Paulo, 2011) e 14 unidades básicas de saúde, das quais foram estudadas duas.

Escolhemos estas duas UBS, porque já as conhecíamos de pesquisas anteriores: uma delas, tradicional, tem menor estrutura física, considerada inadequada pelos profissionais de saúde entrevistados, como será detalhado adiante, por ser uma casa adaptada para UBS; a outra é mista com a Estratégia Saúde da Família, com maior estrutura física, coordenada por uma organização social e recebe residentes de Medicina de Família e Comunidade e alunos de graduação da área da saúde.

\subsection{FORTALEZA}

Em Fortaleza, foram estudados dois serviços de atenção básica da Regional III, a qual apresenta 16 Centros de Saúde da Família (Prefeitura de Fortaleza, 2011). Ambos os serviços têm implantados a Estratégia Saúde da Família e os casos de pacientes com diagnóstico positivo para HIV são encaminhados para um hospital de doenças infecciosas.

Em uma UBS, com menor estrutura física, a testagem anti-HIV é realizada fora da unidade, por não ter equipamentos necessários para que seja realizada na própria UBS, diferentemente das outras três unidades estudadas. Esta dificuldade sobre a distância de realização do teste foi relatada em outro estudo, de observação participante de realização de teste anti-HIV em gestantes em uma outra UBS de 
Fortaleza, que tinham de se deslocar para vários laboratórios, alguns distantes da própria UBS (Araújo, 2008).

A outra UBS apresenta maior estrutura física e tem parceria com uma ONG que cuida de crianças que vivem com HIV.

\subsection{ENTREVISTAS SEMIESTRUTURADAS}

Para alcançar os objetivos deste estudo, realizamos entrevistas semiestruturadas. A entrevista semiestruturada é formada por perguntas fechadas e abertas, circunscrita por um roteiro, para o qual foi realizado um pré-teste, o qual, pela sua qualidade, e porque não houve mudança substancial no roteiro, foi incorporado ao corpo de análise. A pesquisadora definiu os temas, conduziu a abordagem, definiu cortes e a própria conclusão do trabalho, seguindo Schraiber (1995) e Minayo (2008).

As entrevistas visaram buscar: treinamentos ocorridos; condições para aconselhamento; narrativas de casos sobre como foi realizado o pedido e a comunicação de resultado de HIV, a partir de sua memória, na UBS onde atuavam no momento ou em UBS anterior, ou de situações imaginárias, quando não tivessem vivenciado estas situações; e dificuldades e facilidades para realização do pedido e da comunicação do teste anti-HIV.

Procuramos gravar todas as entrevistas, desde que houvesse o consentimento do entrevistado. O gravador traz uma fidelidade do conteúdo e entonações de voz dos entrevistados, porém, pode inibi-los. (Schraiber, 1995)

Não houve esse consentimento em uma entrevista de uma enfermeira de São Paulo e seu conteúdo foi anotado logo após a entrevista.

As entrevistas foram transcritas pela própria pesquisadora, a qual também realizou anotações num caderno de campo sobre as condições da entrevista e suas próprias impressões.

Foram entrevistados gerentes das unidades selecionadas (roteiro anexo I), e profissionais de saúde (roteiro anexo II), que participavam do processo de 
acolhimento do paciente durante a oferta e comunicação do teste anti-HIV. Procuramos entrevistar pelo menos dois médicos e dois enfermeiros de cada unidade, com maior interesse pela pesquisa e disponibilidade de tempo, pois eram as categorias que mais ofereciam e comunicavam o resultado do teste anti-HIV, segundo os gerentes. Em duas unidades, este número abrangia o total de profissionais nessas categorias.

Ao final dessas entrevistas, perguntávamos aos entrevistados se indicavam alguém a ser entrevistado. Neste caso, os profissionais indicavam profissionais que eles consideravam realizar maneiras adequadas e inadequadas de pedido e comunicação de resultado de HIV.

Inicialmente, pensamos em tomar como critério da escolha de profissionais entrevistados o tempo na função de pelo menos um ano, porém, no decorrer do campo, preferimos entrevistar os profissionais mencionados em narrativas de casos de colegas entrevistados e/ou aqueles mais disponíveis em participar da pesquisa, já que a rotatividade de profissionais nas unidades de atenção básica é grande. O conteúdo dessas entrevistas foi aproveitado, porque os profissionais com menos de um ano na função trouxeram experiências anteriores em outras UBS relevantes para refletir sobre possibilidades de atendimentos na Atenção Básica.

Realizamos 21 entrevistas no total.

Em São Paulo, foram realizadas 2 entrevistas com gestores e 9 entrevistas com profissionais de saúde, incluindo uma ACS. A ACS foi entrevistada por ter sido mencionada durante a narrativa de um caso, como assumindo um papel relevante.

Em Fortaleza, foram realizadas 2 entrevistas com gestores e 8 entrevistas com profissionais de saúde.

Para preservar a identidade dos profissionais, escolheu-se numerá-los, sem colocar iniciais, e descrever minimamente suas características individuais: categoria profissional, sexo e tempo na UBS, sem especificar a especialidade médica, por não ser fator diferencial nos resultados. Também se escolheu não nomear as unidades estudadas. Os profissionais estão divididos por UBS 1 e 2, de Fortaleza e UBS 1 e 2, de São Paulo. As UBS 1 são maiores e mais estruturadas do que as UBS 2, por terem maior espaço físico e número de funcionários. 


\begin{tabular}{|c|c|c|c|c|c|}
\hline \multicolumn{3}{|l|}{ FORTALEZA } & \multicolumn{3}{|l|}{ SÃO PAULO } \\
\hline Ocupação & Sexo & $\begin{array}{l}\text { Tempo na } \\
\text { UBS }\end{array}$ & Ocupação & Sexo & $\begin{array}{ll}\text { Tempo } & \text { na } \\
\text { UBS } & \end{array}$ \\
\hline Gerente 1 & Feminino & 5 anos & Gerente 1 & Feminino & 3 anos \\
\hline Médico $1 \mathrm{a}$ & Masculino & 3 anos & Médica $1 \mathrm{a}$ & Feminino & 5 anos \\
\hline Médico $1 \mathrm{~b}$ & Masculino & 4 anos & Médico 1b & Masculino & 4 anos \\
\hline Enfermeira $1 \mathrm{a}$ & Feminino & 4 anos & Enfermeira $1 \mathrm{a}$ & Feminino & 2 anos \\
\hline Enfermeira $1 b$ & Feminino & 1 ano & Enfermeira $1 b$ & Feminino & 1 ano \\
\hline Gerente 2 & Feminino & $\begin{array}{l}\text { Menos de } \\
1 \text { ano }\end{array}$ & ACS 1 & Feminino & 5 anos \\
\hline Médica 2 a & Feminino & 4 anos & Gerente 2 & Feminino & 8 anos \\
\hline Médica 2b & Feminino & 4 anos & Médica 2b & Feminino & Menos de 1 ano \\
\hline $\begin{array}{l}\text { Enfermeiro } 2 \\
\text { a }\end{array}$ & Masculino & 3 anos & Médica 2 & Feminino & 11 anos \\
\hline $\begin{array}{ll}\text { Enfermeira } 2 \\
\text { b }\end{array}$ & Feminino & $\begin{array}{l}\text { Menos de } \\
1 \text { ano }\end{array}$ & Enfermeira 2 a & Feminino & Menos de 1 ano \\
\hline & & & Enfermeira $2 \mathrm{~b}$ & Feminino & 3 anos \\
\hline
\end{tabular}

Todos os entrevistados já haviam solicitado ou discutido com os pacientes a solicitação de teste anti-HIV. Alguns entrevistados relataram acompanhar casos de pessoas que vivem com HIV, porém poucos entrevistados haviam tido a experiência de comunicarem o resultado positivo para HIV. Dos casos acompanhados relatados, as pessoas foram diagnosticadas em serviços especializados ou já haviam sido diagnosticadas quando o profissional começou a trabalhar na atual UBS. Nenhum dos enfermeiros entrevistados comunicou o resultado positivo para HIV. Dos oito médicos entrevistados, apenas quatro comunicaram o resultado positivo.

\subsection{ANÁLISE DAS ENTREVISTAS}

Realizou-se uma análise temática das entrevistas, buscando a interpretação dos significados, dialogando com os conceitos utilizados e a revisão bibliográfica. 
Foram realizadas duas etapas, inspiradas em Minayo (2008):

1. Pré-análise, que pode ser dividida nas seguintes tarefas:

- Leitura flutuante: do conjunto das comunicações. Consiste em tomar contato exaustivo com o material deixando-se impregnar pelo seu conteúdo. No momento de impregnação, segundo Schraiber (1995), o leque de estruturações registrados será abordado como um conjunto, sem deixar de levar em conta a singularidade de cada história produzida. Como particularidade deste trabalho, esta impregnação foi realizada à medida que a pesquisadora transcrevia, uma forma de ter uma escuta atenta ao que foi dito, prestar atenção nos detalhes, vagarosamente e rememorar o contexto da entrevista. Paralelamente, construía as categorias de análise.

- Constituição do Corpus: organização do material de tal forma que possa responder a algumas normas de validade: exaustividade; representatividade; homogeneidade; pertinência. O término da realização das entrevistas ocorreu após esses critérios terem sido alcançados.

- Reformulação de hipóteses e objetivos, após as entrevistas terem sido realizadas.

2. Tratamento dos resultados obtidos e interpretação: busca de significados e divisão do conteúdo das entrevistas em categorias, conforme a compreensão das pesquisadoras.

\subsection{ASPECTOS ÉTICOS}

Para os gerentes dos serviços foi realizado um convite para participarem da pesquisa, de forma voluntária, e solicitada a assinatura do Termo de Consentimento Livre e Esclarecido (anexo III) para entrevista e visitas às unidades mencionadas. A pesquisa foi apresentada, após autorização dos gerentes, para a equipe de funcionários dos serviços. Foram convidados alguns profissionais de saúde para serem entrevistados e também lhes foi solicitado que assinassem o Termo de Consentimento Livre e Esclarecido (anexo IV). 
Para garantir o sigilo, os nomes dos entrevistados, de pessoas mencionadas, dos serviços estudados e de qualquer outro dado de identificação não foram publicados nem divulgados.

Esta pesquisa foi aprovada pelos Comitês de Ética em Pesquisa da Faculdade de Medicina da Universidade de São Paulo, Protocolo $n^{\circ}$ 258/10 (anexo V), e da Secretaria Municipal da Saúde da Prefeitura da Cidade de São Paulo, Parecer $n^{\circ}$ 328/10, CAAE: 0159.0.162.015-10 (anexo VI); e autorizada pela Coordenação do Sistema Municipal de Saúde Escola de Fortaleza e pela Chefia do Distrito de Saúde Secretaria Executiva Regional III, processo 60244/2010.

\section{RESULTADOS E DISCUSSÃO}

Dividimos os resultados nos seguintes tópicos, todos segundo a perspectiva dos profissionais de saúde: primeiro, descrevemos as principais necessidades de saúde em geral da população atendida; segundo, descrevemos os pontos que facilitam e dificultam seu trabalho, de maneira geral, levando em conta que são aspectos contextuais que fazem parte do pedido e da comunicação de resultado do teste anti-HIV e se relacionam com o acolhimento nos serviços; terceiro, analisamos as situações do pedido de teste anti-HIV e, por fim, analisamos a comunicação de seu resultado.

Consideramos relevante descrever o contexto de trabalho, porque entendemos as facilidades para trabalhar como condições "aumentativas de potência" (Sawaia, 2003, 2006) para ação de maneira solidária e respeitosa em relação ao outro, inclusive nos encontros/conversas durante o pedido e a comunicação de resultado de teste anti-HIV. As dificuldades são aqui entendidas, contrariamente, como situações contextuais "diminutivas de potência" (Sawaia, 2003, 2006) para ação, que podem gerar sofrimento nos profissionais e nos usuários.

Em seguida, entramos no tema da prevenção e assistência às DST/aids propriamente dita, começando pela descrição de situações relatadas pelos profissionais de divulgação do uso do preservativo. Dividimos o tópico "pedido de 
exame" entre os principais motivos nos quais eles ocorrem: pedidos baseados em protocolos dos programas de pré-natal, tuberculose e DST; pedidos baseados em populações consideradas de risco e; por fim, grupos e atendimentos clínicos que abordam a sexualidade e favorecem a demanda espontânea do paciente pelo teste anti-HIV.

\subsection{CONTEXTO DO TRABALHO NA ATENÇÃO BÁSICA}

As necessidades de saúde da população atendida identificadas pelos profissionais variaram entre as regiões estudadas. Tanto em São Paulo, como em Fortaleza, foram mencionadas questões relacionadas à pobreza, como falta de lugares para lazer e cultura, associadas à maior vulnerabilidade da população a agravos da saúde.

Dificuldades semelhantes foram relatadas por profissionais entrevistados da Estratégia Saúde da Família em município do Rio de Janeiro, em estudo de Bellenzani (2008), o que, segundo a autora, indica uma compreensão dos profissionais sobre a relação entre violações de direitos humanos e piores índices de saúde das populações, conforme analisado por França Junior e Ayres (2003).

Os atendimentos mais mencionados se relacionam com o pré-natal, controle da diabetes e pressão alta, prioridades da Estratégia Saúde da Família. Em Fortaleza, foram mais mencionadas dificuldades estruturais, como falta de saneamento básico.

O HIV e a aids não aparecem como uma das principais necessidades da população, tanto para os profissionais de saúde de Fortaleza, como para os de São Paulo.

Apenas uma enfermeira de Fortaleza mencionou as DST como uma das principais doenças da população, o que pode ser indicativo de uma maior organização do programa municipal de DST/aids, em relação a São Paulo.

Foram elencados alguns elementos que são considerados como facilitadores para o trabalho, de maneira geral:

- ter um número de profissionais no serviço diversificado e considerado suficiente para um bom atendimento, incluindo o ACS; 
- UBS que recebem estudantes de universidades e cujos profissionais trabalham como supervisores desses estudantes, favorece a formação continuada dos profissionais, pelo contato com professores das universidades e maior possibilidade de realização de cursos de aperfeiçoamento;

- bom relacionamento entre os profissionais da equipe e reuniões periódicas para discutir o processo de trabalho também foram lembrados como qualificadores do trabalho. Dos quatro serviços estudados, foram relatadas reuniões de equipe em três, nos dois de Fortaleza e no serviço com equipe mista de São Paulo. Nesses três serviços, há implantação da Estratégia Saúde da Família.

Da mesma maneira, foram elencados alguns elementos que são considerados como dificultadores para o trabalho, de maneira geral:

- Os profissionais reclamaram da grande demanda e do número de atendimentos que precisavam fazer; de falta de estrutura física, como salas e computadores rápidos para envio de dados de atendimentos.

- Alguns consideraram grande a sobrecarga de trabalho.

- Em Fortaleza e na UBS tradicional em São Paulo, houve reclamação sobre falta de profissionais.

- Em Fortaleza, uma das UBS era considerada perigosa, por violência ao redor e profissionais comentavam que colegas haviam sido assaltados. Em uma UBS de São Paulo, a violência é relatada como desafio a ser trabalhado, especialmente com jovens.

- Uma dificuldade no trabalho que apareceu em Fortaleza e não em São Paulo, foi a "politicagem", a influência de vereadores na autonomia do processo de trabalho das UBS e a indicação política para profissionais na unidade.

- Alguns profissionais relataram dificuldades na referência e contrarreferência: embora os profissionais da UBS devam solicitar informações sobre os procedimentos em relação ao cuidado de pacientes acompanhados em outros serviços, para a coordenação do cuidado, dificilmente conseguem resposta. 
A UBS tradicional estudada de São Paulo, sem implantação da Estratégia Saúde da Família, foi a única em que foi relatada falta de espaço e tempo para reunião de equipe, justificada pela gestora pela alta demanda. As reuniões acontecem somente de maneira informal, porque não são autorizadas pela Prefeitura. A reunião entre a gerência e o restante da equipe se restringe a recados rápidos. A falta de reuniões em UBS tradicional, comparativamente às UBS com implantação da Estratégia Saúde da Família também foi observada em avaliação realizada em 37 municípios do Estado de São Paulo (Castanheira et al., 2009), através de questionário estruturado autorrespondido pelos gerentes e/ou equipe técnica das unidades da rede básica: a realização de reuniões periódicas de equipe foi relatada por $40 \%$ do total das unidades (42/105), entre as unidades com implantação da Estratégia Saúde da Família, a periodicidade de reuniões chega a $84,6 \%$ (22/26), enquanto nas UBS tradicionais, as reuniões são periódicas em apenas 31,4\% (16/51) das unidades.

As questões elencadas pelos profissionais que facilitam e dificultam o trabalho de maneira geral são aspectos relacionados à gerência de recursos para atenção básica e à organização do serviço. Observamos que estas condições podem dificultar ou impossibilitar a prática do aconselhamento, conforme preconizado pelo Ministério da Saúde (Brasil, 2004), pois este demandaria a dedicação de um tempo suficiente de conversa com o usuário e um espaço de apoio para profissionais de saúde, como reuniões de equipe, para troca de experiências e discussão de casos. Segundo revisão de estudos internacionais de artigo mencionado de Obermeyer e Osborn (2007), nos países onde o sistema de saúde possua recursos limitados, os profissionais de saúde podem ter pouca capacitação e sua carga de trabalho ser tão pesada, que eles não encontrem tempo ou espaço para realizar o aconselhamento. Mesmo quando recomendado, a testagem e o aconselhamento podem não ser sistematicamente oferecidos. A oferta da testagem anti-HIV pode depender da consideração do profissional de saúde sobre a capacidade do usuário receber notícias difíceis. Alguns estudos (id. Ibid.) relatam que no aconselhamento realizado para camadas menos privilegiadas da população, geralmente o tempo é insuficiente e a informação inadequada.

Relacionado especificamente sobre a área das DST/aids, foram relatadas diferenças entre Fortaleza e São Paulo. Segundo os profissionais entrevistados de 
Fortaleza, para garantir a informação e consentimento pré-testagem, há um consentimento escrito especialmente para a testagem anti-HIV. Ainda, segundo eles, há um profissional de saúde que é responsável pelo cuidado nesse tema, no caso das duas UBS estudadas, uma enfermeira.

Os profissionais de Fortaleza mencionaram uma capacitação relacionada às DST/aids oferecida pela Prefeitura, na qual são convidados a participar os representantes responsáveis pela área de DST/aids de cada UBS. É recomendado que os profissionais capacitados repassem os conteúdos da capacitação para outros profissionais da UBS nas "rodas de gestão", momentos nos quais os profissionais se encontram para discutir temas e questões relevantes da UBS. Estas "rodas" podem ter peridiocidade variada entre uma semana e um mês.

Uma diferença entre Fortaleza e São Paulo foi a presença mais visível e citada da Coordenação Municipal de DST/aids de Fortaleza nos discursos dos profissionais da atenção básica, ao mencionarem capacitações oferecidas por esta, e nas UBS, pela presença de cartazes informativos, o que não foi citado, nem observado em São Paulo.

"Não [perguntada se recebeu preparação específica para pedido e comunicação de resultado de teste anti-HIV]. (...) Não, não. Nunca, nunca. Nem existe isso aqui pra gente. Nem se oferece esse tipo de qualificação, capacitação." (Enfermeira 1 a de São Paulo)

"Eu acho que a gente tem tido poucas capacitações nesse assunto ultimamente. A gente tem tido mais capacitações voltadas pra pré-natal, que esse assunto é um deles, mas ele passa muito un passant, sem muito aprofundamento e doenças transmissíveis de outra ordem, como dengue, vive tendo treinamento, tuberculose. Tem tido pouco investimento na área da aids, desde que eu entrei na gerência." (Gerente 1 de São Paulo)

Entretanto, essa mesma gerente questionou se as capacitações seriam capazes de superar as dificuldades que alguns profissionais têm com as questões éticopolíticas levantadas pela epidemia do HIV:

"O que acontece é que, aqui, não sei se você já sabe, mas, por exemplo, só pede exame nível superior. $O$ auxiliar de enfermagem não pede exame. Só enfermeira e médico. Eles têm formação de base. Os médicos que eu tenho hoje em 
dia quase todos têm, são médicos de família. Não são todos, mas quase todos. E eles têm formação. E na residência de medicina de família, isso é muito debatido e muito trabalhado. Então se espera que ele saiba fazer isso. As enfermeiras mais ou menos idem. Quase todas são especializadas em saúde da família, onde essa temática é muito desenvolvida. Eu acho que o problema não é preparo. Eu acho que o HIV tem dentro dele os valores das pessoas, o julgamento e as pessoas podem até ser preparadas e na hora que faz a aula concordar, achar que tem questões éticas, mas, por outro lado, a gente vê que tem um preconceitinho embutido em algumas pessoas. Tem algumas pessoas que lidam muito bem." (Gerente 1 de São Paulo)

Assim, esta gerente coloca que o estigma e a discriminação que os profissionais possuem relacionados ao HIV podem não ser necessariamente transformados em formações ou capacitações, mesmo as que tenham um tempo considerável de duração, como a residência em saúde da família, no caso de médicos e enfermeiros.

Outra médica concorda que a aids não tem sido um tema priorizado nas capacitações pela Prefeitura. Relata que se recorda vagamente de uma capacitação em São Paulo, porém nada que tenha sido marcante e que os profissionais capacitados deveriam ser multiplicadores "teoricamente", porém, na prática há uma dificuldade para efetivar a transmissão dos conhecimentos e reflexões obtidos para os pares.

"Capacitação que a Prefeitura faz e convoca os funcionários pra irem, então metade participa, porque como tem capacitações, a ideia é não ir o grupo inteiro, é ir um grupo menor, porque não dá pra parar o serviço, vai o grupo menor e teoricamente esse grupo serviria como multiplicador do restante do posto. Então já teve sim, hepatite. Acho que HIV já teve, mas nada que tenha me deixado uma recordação muito forte." (Médica 1 de São Paulo)

Uma enfermeira de São Paulo, responsável pela área de vigilância da mesma unidade das profissionais citadas, lembra que realizou uma capacitação de um dia, oferecida pela organização social que administra a UBS. No entanto, como ela atende na clínica em poucos horários, apenas casos de atendimento de demanda espontânea, não conseguiu repassar os conteúdos e reflexões para outros 
profissionais do serviço, o que remete à dificuldade relatada pela médica na fala anterior.

"A gente da vigilância teve algum treinamento pra isso, mas como não é a gente que tá nas consultas todo dia, então isso, a gente não consegue exercer tanto isso. (...) A gente recebeu [treinamento], a gente teve uma aula, na verdade, (...) a gente fez lá um psicodrama, um role-play, abordar a questão de como solicitar o exame, como dar o resultado, sendo o resultado positivo ou negativo, tudo o que for interessante, mas foi o que a gente teve até agora, aqui em trabalho, em serviço, foi o que a gente teve até agora (...), mas isso é só pros enfermeiros da vigilância. (...) Mas teve esse dia que foi bem interessante, trouxe várias questões, tudo, e que no momento, seria interessante a gente poder discutir com a unidade inteira, mas eu acho que antes até de a gente chegar nessa questão da coisa mais específica do HIV, eu acho que a gente tinha que conseguir falar um pouco mais sobre sexualidade." (Enfermeira 1b de São Paulo)

A fala desta enfermeira enfatiza um aspecto importante dos encontros relacionados com a testagem anti-HIV: a necessidade de os profissionais conseguirem lidar com questões ético-políticas, relacionadas a gênero; estigma; discriminação; falta de respeito à autonomia do outro, e "deslize" da autoridade técnica para a moral. Estes temas apareceram na análise das narrativas dos casos relacionados e serão detalhados nos próximos tópicos deste trabalho.

Em Fortaleza, foi mencionada limitação de capacitações de curta duração, como ilustrado pela dificuldade narrada por uma enfermeira de Fortaleza em lidar com o sofrimento gerado na comunicação de um resultado positivo. Esta enfermeira relatou ter recebido uma capacitação pontual, oferecida por uma ONG, em parceria com o governo. Ela relata muita insegurança em comunicar um resultado positivo para HIV, pelo sofrimento que geraria no usuário, especialmente no caso de crianças, pela dúvida sobre a qualidade de vida que estas poderiam ter, tema que não foi abordado nesta capacitação.

“Eu já fiz treinamento sobre o aconselhamento, mas assim, a qualidade de vida de uma criança HIV é que eu confesso que eu não sei. Eu muito pouco sei sobre o assunto. (...) Esse treinamento foi (...) no começo do ano, é uma ONG, mas que tem parceria com o governo. (...) Aí vieram umas pessoas de fora, uma assistente social, 
uma psicóloga, pra falar sobre o aconselhamento. Na verdade, foram dois dias e nesse aconselhamento o que eu senti é que elas tentaram passar pra gente, é que ainda hoje, mesmo sabendo do tratamento, existe muito estigma da doença, que não é fácil ainda, que mesmo o profissional sem querer, ele passa, quando fala em HIV, o profissional sem querer muda a posição, bota a mão na cabeça, tudo isso a pessoa que tá olhando pra você já percebe que você já fica ansioso, que você, vixe, vai dar uma notícia dessa. Então ninguém dá um resultado positivo como pra hipertensão e diabetes, você já dá envolvendo um clima de que uma coisa muito ruim aconteceu, então no aconselhamento ela mostrou isso pra gente através de grupos, através de teatros que a gente fazia. Ela pedia: 'Faça você, como se você fosse pedir o aconselhamento pra pessoa e fosse dar o resultado positivo.” (...) Ai a gente já ficava nervoso e gaguejava. Aí a gente via que mesmo a gente sabendo como orientar a pessoa, mas mesmo assim a gente ficava nervoso. É diferente de quando a pessoa chega aqui, 'Ô, seu fulano, sua glicemia deu alterada, então provavelmente o senhor tem diabetes. Vou encaminhar o senhor pro médico pro senhor conversar com ele.' Todo mundo aceita diabetes. É ruim diabetes e tudo o mais. 'Ai, eu tenho diabetes, colesterol, hipertensão.' Então a pessoa fala abertamente, mas é uma doença crônica, que pode causar algumas complicações na sua vida, mas você fala. E o HIV não, você não fala abertamente que tem HIV." (Enfermeira 1b de Fortaleza)

Esta fala indica que não há implantada na prática dos serviços uma condição facilitadora para realização de aconselhamento na atenção, recomendada pelo Ministério da Saúde (Brasil 2004a), "encontros periódicos" e "reorganização interna processual", que permitissem a capacitação contínua e problematização das situações cotidianas. Apesar de não haver esta periodicidade, destacamos a relevância da capacitação mencionada para a reflexão dos profissionais sobre sua prática cotidiana, ao serem convidados a simular situações concretas, de forma a abordar os afetos envolvidos e a perspectiva ética.

\subsection{RECOMENDAÇÃO DO USO DO PRESERVATIVO}

Alguns profissionais de saúde relatam que recomendam o uso do preservativo nos atendimentos individuais e em grupo. Uma médica de São Paulo 
cita como exemplo a recomendação de uso de preservativo para uma paciente, cujo namorado estava com lesões de HPV.

Entretanto, uma gestora reclamou sobre a falta de preservativos masculinos, porque, segundo ela, os usuários retiram os preservativos para venda. Em sua unidade, o preservativo somente é dispensado na farmácia, no máximo uma vez ao dia e cabe ao funcionário da farmácia reconhecer a pessoa para não distribuir mais do que isso:

"Então tem que ter regras, porque tem o pessoal que vem buscar também pra vender. (...) A gente tenta ver, reconhecer as pessoas, se eu dei pra ela 15 camisinhas de manhã, à tarde eu não vou dar de novo." (Gestora 1 a de Fortaleza)

Em São Paulo, uma enfermeira responsável pelo material da unidade, reclama dos poucos preservativos enviados pela Prefeitura para unidade e relata que já chegou a faltar preservativos para usuários:

"Na semana passada, quando eu recebi o material, eu vi que só vieram 144 preservativos para (...) 15 dias. Então é muito pouco se você pensar que a gente tem uma população de 19 mil pessoas e eu acho que, de jovens. (...) E já faltou várias vezes preservativo e a gente já viu várias vezes um grupinho de meninas adolescentes vindo pegar preservativo e a gente não ter preservativo pra oferecer." (Enfermeira 1 b de São Paulo)

Em UBS estudadas no Rio de Janeiro, o número de preservativos que cada usuário pode retirar por mês é limitado, o usuário deve estar cadastrado e retirá-los somente na farmácia (Bellenzani, 2008).

Destacamos dois profissionais de Fortaleza que relatam abordagens criativas em grupo, relacionadas com atendimentos individuais, de prevenção às DST/aids, com a recomendação do preservativo, as quais facilitaram o surgimento da demanda pela testagem anti-HIV, e que podem estar relacionadas com o fato de terem sido capacitados pela Prefeitura, conforme as falas abaixo.

"Recentemente, o ano passado, eu acho que quase todos os nossos profissionais passaram por uma capacitação. Eu acho que era mais de 60 horas. (...) O que foi feito nessa capacitação foi a história do pré-aconselhamento e do pósaconselhamento no caso do HIV/aids, né? O que a gente trabalha muito aqui no HIV/aids, quais são as oportunidades que a gente tem: pré-natal, esse aí é quando a 
gente consegue solicitar mais, oferecer mais os exames. Sempre ter o cuidado... Às vezes atrasa muito o atendimento, mas a gente não... Mas o ideal é fazer sempre o pré-aconselhamento, reúne as mães, porque é aquele catatau de solicitação de exames da rotina do pré-natal e a gente chama mais a atenção pra questão do HIV. E faz todo aquele pré-aconselhamento: o que é, como pega, não vai morrer por causa disso, tem tratamento, tal... (...) Antes de começar o atendimento, pra não ficar sempre repetindo a mesma coisa, a gente senta, chama elas aqui dentro da sala e fala a questão da importância do exame, pro bebê, pra mãe, a detecção precoce, a questão do companheiro também tem que fazer, do resultado, que quem só pode pegar é a mãe, tem que marcar com uma profissional médica, é sigiloso, se não vier pegar, e aí? Ninguém pega. E o que fazer depois? Novamente, toda aquela rotina que a gente faz. (...) A gente tem oportunidade de tratar na "prevenção" também. A gente vê muito aqui a questão do condiloma. " (Enfermeiro $2 \mathrm{~b}$ de Fortaleza)

"O ano passado, também, eu fiz um treinamento pela prefeitura sobre DST/aids e hepatites virais. Estavam fazendo eu, uma enfermeira e um dentista. E, assim, umas coisas que a gente viu lá foram passadas pros profissionais aqui em roda, como, exatamente, todo mundo que quisesse fazer, disponibilizar, facilitar o acesso desses pacientes, a solicitação de alguns exames, tipo HIV. (...) Por exemplo, não dá pra fazer isso, realmente a gente não faz isso em toda consulta, mas no planejamento familiar, tá entendendo? Em consultas com os adolescentes, a gente acaba pegando mais adolescentes, porque, na verdade, era pra ser oferecido pra todos, né? Mas, no geral, pra todas as gestantes eu ofereço, pergunto se elas querem fazer o exame. No geral é isso." (Médica 2b de Fortaleza)

O enfermeiro mencionado relatou uma ação diferenciada para uma UBS, a recomendação de preservativos para um grupo de idosos:

"Foi no Dia da Vacina, a gente trabalhava com várias atividades, dentre elas, DST/aids. Então entravam dez idosos, depois saíam e entravam mais dez. E assim, a participação foi quase $100 \%$ deles. Perguntar, tirar dúvidas, a história do uso da camisinha, a gente fez uma demonstração de maneira bem cômica, pegava o cabo de vassoura, a colega, a gente brincava assim: 'Como você tá?' A questão da ereção: 'Como tá a ereção de vocês? Tá assim, tá assim ou tá assim?' [para baixo, para frente ou para cima] Foi bem legal a participação deles (...) é uma pessoa que 
já trabalha com eles, com terapia comunitária, com extramuros, com vacinação, então você tem a confiança deles. ” (Enfermeiro 2a em CSF em Fortaleza)

Este enfermeiro também relatou a recomendação de preservativo em atendimentos individuais e cita o exemplo de um atendimento de uma gestante, que mencionou desconfiar da infidelidade do marido. O sexo sem preservativo não foi citado como motivo em si para iniciar uma conversa sobre a recomendação do preservativo, conforme prescrito nos manuais do Ministério da Saúde, mas somente quando associado a um comportamento de risco, como a desconfiança da presença de outras parcerias sexuais ou uso de drogas pelo companheiro, inclusive álcool. Foram discutidas alternativas para as dificuldades cotidianas na prevenção, estimulada por informações advindas da capacitação:

“Justamente pra conscientizar: 'Se ele é tão danado, pelo menos tá usando a camisinha em casa?' Porque tem marido que resiste a usar camisinha em casa.(...) No caso das meninas, tem marido que elas relatam que não quer usar o preservativo, então chega o cara embriagado, drogado. Então nesses casos seria interessante a mulher usar o preservativo feminino, porque ele não vai nem notar que ela tá de preservativo e ela pode colocar antes da relação, então a gente trabalha muito com essa história. Esse é um processo que tá começando agora." (Enfermeiro 2a em CSF em Fortaleza)

Ele relatou ter participado de uma capacitação, na qual foi abordada a questão do uso do preservativo feminino:

"Na última reunião que a gente teve, a questão do uso do preservativo feminino, tá certo? Porque o município tá tentando implantar, justamente porque (...) Isso foi passado na reunião na regional pra gente trabalhar também a história do uso do preservativo feminino. Tá até aqui os informes que foram dados pra gente também (...) Foi repassado a história do preservativo feminino. Foi-nos dado um material educativo, que é alguns jingles do Ministério da Saúde, que é o pênis que o pessoal risca no banheiro das escolas, (...) com carinha, olhinho e tudo, adolescente vai e olha ele lá no cantinho atrás da... e também tem os desenhos das meninas, dos órgãos sexuais femininos, então ele sai atrás e todo mundo corre dele, porque ele tá sem preservativo. Aí a adolescente vai lá, nota e bota um preservativo nele. Aí as meninas correm tudo atrás dele, por causa do preservativo, então você tem que 
tomar cuidado, porque você pode estar chamando também a questão de ter mais relação sexual, porque tá protegido, não é por aí." (Enfermeiro 2 a de Fortaleza)

Neste relato, este enfermeiro relatou um limite de suas ações educativas, pois remete a valores morais de que liberar a sexualidade para os jovens é igual a estimular o aumento de relações sexuais, visto como indesejável. Observamos que o desejo da ou do adolescente precisa ser discutido e respeitado caso a caso, mas não compete nunca ao profissional dizer quando, com quem ou com quantos cada um vai querer transar, pois isto seria uma intervenção indevida do Estado e desrespeito aos direitos sexuais e reprodutivos. Entretanto, os profissionais podem possibilitar momentos de reflexão e fornecer informações técnicas sobre formas de prevenção às DST/aids, respeitando seu direito à informação e à saúde.

Esta fala remete às dificuldades de os profissionais apresentarem discursos técnico-científicos, afetivos e conseguirem escutar e validar os desejos dos adolescentes, em práticas "acolhedoras”.

Outro relato, de uma médica, mostra outra possibilidade de discussão sobre uso de preservativo na Atenção Básica, em um grupo de prevenção às DST/aids, organizado por ela como parte de atividade de ensino do PET - Programa de Educação Tutorial:

“A gente fez uma atividade no $1^{\circ}$ de dezembro, Dia Mundial de Luta contra a Aids. A gente fez aqui na unidade, a gente foi na comunidade, fizemos distribuição de preservativos, de panfletos. Fizemos aqui na unidade, na sala de espera exposição. Mostramos o uso correto do preservativo. Falamos do preservativo feminino. Foi transmitido pra eles formas de contágio, como era a doença, falado um pouco sobre o tratamento, tudo e a gente levou pra comunidade também e a gente sempre tenta deixar aberto pros pacientes, quem quiser é só solicitar, tá aberto, qualquer pessoa pode fazer. Eu sempre digo isso pros pacientes, de uma maneira geral. (...) Uma outra vez eu fiz uma atividade com um grupo de adolescentes aqui no posto. A gente reuniu esse grupo de adolescentes, que era um grupo que participava de um grupo no CRAS, que era no Centro de Referência e Assistência Social e a gente pediu que eles escolhessem um tema. E eles escolheram DST e eu e uma dentista, a gente fez uma palestra pra eles sobre eles. A gente conseguiu álbum seriado, preservativo e a gente conversou. Foi bem legal, uma 
conversa mesmo, onde a gente explicou várias coisas. E aí falamos do HIV, do uso correto da camisinha. Deixamos a unidade de saúde aberta pra eles, que qualquer coisa que eles quisessem, podiam vir aqui, que tava aberto pra solicitação de exames, e a dentista falou também da DST na boca, através do sexo oral. Foi bem legal." (Médica 2 b de Fortaleza)

Esta atividade buscou esclarecer usuários sobre o uso do preservativo e o acesso aberto a todos da testagem anti-HIV no serviço de Atenção Básica. Entretanto, observamos que essas atividades precisam ser ampliadas, inclusive para outros membros da equipe, pois alguns agentes comunitários de saúde, em conversas informais com a pesquisadora, relataram que não sabiam sobre a testagem anti-HIV na unidade, exceto pelo fato que havia um cartaz na fachada recomendando o teste, numa campanha do Ministério da Saúde do "Fique Sabendo".

A seguir, iremos analisar aspectos relacionados ao aconselhamento pré e pósteste anti-HIV propriamente dito.

\subsection{OS ENCONTROS SEGUNDO AS PRINCIPAIS SITUAÇÕES DE PEDIDO DO TESTE}

Pedidos de Teste Anti-HIV Baseados em Protocolos dos Programas de PréNatal, Tuberculose e DST

Em relação à organização do trabalho, a maioria dos pedidos de teste antiHIV são oferecidos na atenção básica rotineiramente apenas quando baseados em protocolos do Ministério da Saúde, relacionados aos programas de tuberculose e ao pré-natal, segundo os profissionais.

"A gente pede de rotina o HIV no tratamento de tuberculose, pra todas as pessoas no pré-natal, né? (...) Às vezes quando ela vem por algum outro motivo, relacionado à DST, a gente orienta a importância do HIV, do anti-HIV." (médica 2a de Fortaleza) 
$\mathrm{O}$ oferecimento rotineiro do teste anti-HIV durante o pré-natal e os procedimentos decorrentes quando o exame é positivo têm o potencial de reduzir a ocorrência de novos casos de HIV e, conforme dados do Boletim epidemiológico de aids de 2010, este procedimento vem sendo efetivo, pois houve uma redução na transmissão vertical de 44,4\% de 1999 a 2009 no país (Brasil, 2010a).

Estudo transversal analisou a testagem anti-HIV em 1998 e 2005, conduzido com homens e mulheres de 16 a 65 anos, com amostras representativas do Brasil urbano (em 1998, $n=3.600$ e 2005, $n=5.040$ ), e concluiu que houve aumento entre as mulheres, devido ao pré-natal: $27,2 \%$ das mulheres relataram o pré-natal como razão para testagem em 1998 e em 2005, 46\% referiram tal motivação. Segundo os autores, a vinculação da testagem anti-HIV à assistência pré-natal, solicitada rotineiramente e sem consentimento e orientação adequados, fez a testagem subir para $60 \%$ das mulheres entre 25 e 34 anos. No estudo citado, 55\% dos entrevistados não receberam aconselhamento e 1,6\% não sabiam que estavam sendo testados. (França Junior et al., 2008).

Todos os entrevistados afirmaram que informam sobre a realização do exame anti-HIV no pré-natal.

No caso do pré-natal, pelo pedido do teste anti-HIV fazer parte da rotina e ser raro o resultado do exame ser positivo, nem sempre são dadas informações e a preparação para caso isso aconteça.

"Como a gente pede muito [exame anti-HIV no] pré-natal, a orientação é muito, faz parte, tá entendendo? Assim, não é uma coisa muito, a gente não prepara pra se der positivo, até porque a chance é assim tão irremota, a gente não prepara a pessoa: 'Olha, você vai fazer exame HIV, não sei o quê.'.' (Médica 2 a de Fortaleza)

Alguns mencionaram que pela demanda ser grande, nem sempre é possível realizar um atendimento demorado, no qual sejam dadas muitas informações ou realizada grande discussão. Além disso, pensar na possibilidade de infecção para alguém casado poderia, na opinião dos profissionais, gerar uma crise de confiança no casal por levantar suspeitas de infidelidade própria ou do parceiro, comportamentos moralmente reprovados.

Uma solução encontrada em Fortaleza para garantir a informação e consentimento pré-testagem, mencionada pelos profissionais, é um consentimento 
escrito especialmente para a testagem anti-HIV, que deve ser assinado pelas gestantes, o que é percebido como uma burocracia por alguns e por outros, uma mistificação do exame para HIV, como relata um médico:

"A questão de você solicitar no mesmo papel, que você solicita outros exames, então o paciente já vai ver que aquilo é uma coisa que não precisa ser separada, não é uma coisa que tá sendo só pedida pra ele." (Médico 1 a de Fortaleza)

Diante da testagem prevista em protocolos, os profissionais devem se confrontar com questões relacionadas a valores ético-políticos e situações que envolvem "dilemas morais", especialmente em casos de recusas de gestantes. Para alguns profissionais, as gestantes podem se diferenciar de outros casos previstos em protocolos, por ela ter o dever de realizar os exames, independente de sua vontade, pela preocupação com o feto. Não se trata de uma postura "acolhedora" pensando no "acolhimento", conforme mencionado na introdução, desenvolvido por Teixeira (2003), por interromper o diálogo e a escuta do sujeito e colocar em dúvida os seus direitos. Como ilustrado pela falta de uma médica de Fortaleza:

“Eu não coloco a gestante como opcional. Eu tenho paciente de TB, que a gente explica, o paciente fala: 'Olha, doutora, eu não quero fazer.(...) Não quero fazer. Eu trabalho, não vou vir até aqui pra fazer exame não. Não tem perigo não. Mas olha, o exame é importante, pro tratamento, pra tudo.' 'Não, doutora, não tem perigo não, não vou não. Não quero fazer.' É diferente da gestante. O paciente de $T B$, eu acho que ele tem esse direito de escolher ou não fazer o anti-HIV. A gestante eu acho que ela não tem muito esse direito, porque não é só a vida dela que tá em risco, sabe?" (Médica 2a de Fortaleza)

Esta médica diferencia o paciente de tuberculose, identificado como homem e a paciente gestante, o que nos faz pensar que, por certo aspecto, os homens têm mais autonomia sobre sua própria saúde, para poder afirmar ou recusar determinados procedimentos. Em análise sobre como se lida com a sexualidade em serviços de saúde, através de observação participante em dois serviços de atenção básica em Natal, os autores observaram movimentos de resistência à submissão a imposições colocadas por profissionais de saúde, ao que associam aos "atributos de força e poder 
e a dificuldade de se sujeitar ao outro, característicos do padrão hegemônico de masculinidade" (Pinheiro et al., 2011, p. 856).

No entanto, normas do Ministério da Saúde recomendam claramente o direito das mulheres receberem as informações sobre o teste anti-HIV, refletirem e poderem recusá-lo, assim, a prática de alguns profissionais contraria o protocolo de atenção ao pré-natal (Brasil, 2005b):

O profissional deve (...) garantir o caráter confidencial e voluntário do teste anti-HIV. Durante todo esse processo, a gestante deverá ser estimulada a expressar seus sentimentos e dúvidas em relação a essas informações. (Brasil, 2005b, p. 28)

Os profissionais de saúde, nesse caso, transpõe sua autoridade técnica em autoridade moral, "impedindo o exercício de escolhas pelo sujeito "dominado" (D’Oliveira e Schraiber, 1999, p. 346).

Estudo de Silva e Ayres (2009) sobre estratégias para comunicação de diagnóstico de HIV a parceiros sexuais através de entrevistas com profissionais de saúde de serviços especializados em DST/aids em São Paulo e observação de grupo focal com usuários, teve um resultado semelhante. No caso de crianças em risco de serem infectadas pelo HIV, os profissionais podem fechar as possibilidades de escolha do paciente. Eles podem agir de maneira autoritária e abrir mão da busca de soluções compartilhadas. Podem ameaçar e coagir como forma de intimidação do paciente para que ele aja conforme o que os profissionais consideram mais adequado: no estudo citado, comunicar o diagnóstico de HIV para um parceiro, para que possa realizar a profilaxia anti-HIV ou o tratamento da criança infectada.

As autoras da revisão mencionada anteriormente, Obermeyer e Osborn (2007) analisam que o consentimento informado para testagem é um processo permeado por relações de poder e pela cultura. Os participantes comumente não entendem as informações fornecidas. Estudos realizados na Europa indicaram que 10 a 20\% dos participantes foram testados sem seu conhecimento. Os participantes podem concordar por diversos motivos, que não seja o consentimento livre e esclarecido: por estarem acostumados a aceitar as requisições dos profissionais de saúde; por pensarem que assim serão atendidos de melhor maneira; por pensarem que não podem recusar a testagem, ou, se recusarem, poderão sofrer consequências adversas. As situações analisadas neste dissertação são concordantes com estudos nacionais e 
internacionais, indicam que o consentimento nem sempre é tão "livre", mesmo quando "esclarecido", pois pode ser influenciado pelo modo como estão conformadas as relações de poder nos serviços, que induzem os usuários a um cálculo sobre as vantagens/desvantagens em se aceitar ou não a realização dos exames. A predisposição "afetiva" dos trabalhadores a fazerem ou não o pedido do teste combinam em diferentes proporções aspectos ético-políticos e aspectos ligados às condições de trabalho.

Uma das narrativas na qual houve um aconselhamento com espaço para manifestações dos afetos foi narrado por uma enfermeira. Uma gestante ficou com receio em realizar o teste anti-HIV, por se considerar em risco para a infecção, por ser usuária de drogas injetáveis e, após argumentação da enfermeira sobre cuidados em relação a sua própria saúde, a possibilidade de tratamento e a prevenção de infecção para o bebê, a usuária aceitou realizá-lo.

"Teve uma que eu perguntei se ela queria fazer, ela parou assim: 'Posso pensar?' 'Pode, você pode pensar.' Mas aí eu comecei a falar da importância. Ela falou: 'É porque eu tô com muito medo.' Porque ela até falou que não tinha bem certeza de quem era o pai do filho dela. Ela era usuária de drogas, tinha até um fator de risco, de drogas injetáveis. (...) Ela sentiu receio em realizar o exame, mas aí eu comecei a falar que já existe o medicamento, o quanto antes ela usar, existe a diferença entre se ter o vírus e se ter a doença, né? E a questão do bebê também pra prevenir que o bebê venha a ter. Então depois que eu argumentei com ela, ela se sentiu mais tranquila e resolveu fazer o exame. E não deu, nos retornos depois, graças a Deus não deu positivo. Foi um caso assim que eu lembrei, por conta que quando eu solicitei o exame, eu vi no olhar dela que ela realmente tava com muito medo." (Enfermeira 2b de Fortaleza)

Esta enfermeira teve uma postura "acolhedora", sob uma perspectiva aberta e não julgadora ou prescritiva, ao buscar compreender os medos da paciente em realizar o teste anti-HIV, oferecer-lhe informações técnicas sobre o tratamento, em linguagem acessível e mostrar preocupação com o cuidado de sua saúde e do bebê.

Um caso no qual houve oferecimento de testagem anti-HIV no pré-natal foi relatado por uma médica de Fortaleza acerca uma paciente evangélica, gestante, em 
torno de 25 anos, que se recusou a fazer o teste anti-HIV, mesmo com a insistência da médica e esta respeitou esta decisão:

"Só que eu já atendi uma gestante que ela disse: 'Não, eu não quero fazer.' Aí eu perguntei por que ela não queria fazer. Ela disse que porque achava que não tinha necessidade, que ela tinha certeza que ela não tinha e que o marido dela também não. Então ela não quis fazer. (...) Você fica assim, eu, eu, eu [parece demonstrar espanto e nervosismo], depois, assim, eu tentei perguntar porquê ela não queria fazer, que não tinha problema. Aí ela reafirmou que não, que achava que não era necessário. Aí assim, eu fiquei, você fica um pouco assim, porque você sabe que na verdade todo mundo pode ter risco, se você tem relação, se você tem, principalmente, tava grávida, então, todo mundo tem risco. Então na verdade seu desejo é que o paciente faça." (Médica 2 b de Fortaleza)

Destacamos que esta paciente se recusou a realizar somente o teste anti-HIV e não os outros, o que remete ao simbolismo da aids ligado ao estigma $\mathrm{e}$ discriminação. Pode ser que os outros testes não tenham sido informados com detalhamento, já que não têm um termo de consentimento específico, como o teste anti-HIV. Apesar de a médica desejar que a usuária fizesse o teste anti-HIV, pela informação técnica de que qualquer pessoa que faça sexo sem preservativo pode estar em risco, respeitou sua decisão sobre não realizá-lo. Observamos, no entanto, sua dificuldade, pois ela teve de se confrontar com um dilema moral: como lidar com os interesses individuais da paciente, os do futuro bebê e a preocupação coletiva em conter a epidemia de HIV?

O saber técnico, ao ser operado nos casos concretos, gera conflitos e tensões, que mobilizam núcleos afetivos e exigem respostas construídas singularmente em cada encontro. Segundo Schraiber (1997), todo ato médico envolve uma decisão pessoal na aplicação do conhecimento, expressando-se como trabalho reflexivo.

As questões religiosas não são destacadas pelo material do Ministério da Saúde sobre aconselhamento em DST/HIV/aids para Atenção Básica (Brasil, 2004a). Este manual destaca, no entanto, a "vulnerabilidade das mulheres, que se encontram em situação de submissão na relação com os homens para negociar o uso do preservativo, principalmente com seus parceiros fixos.” (Brasil, 2004a, p. 14). 
Estudo transversal brasileiro (Berquó et al., 2008) analisou dados coletados entre 1998 e 2005 e relata menores proporções de uso de preservativo entre os seguidores da religião protestante e pentecostal, em relação àqueles que declaravam não ter religião ou ser de outra religião, o que pode indicar uma maior vulnerabilidade social (Ayres et al., 2003).

Para lidar com a vulnerabilidade social (Ayres et al., 2003) do grupo de pessoas unidas em relação a questões de gênero, e a vulnerabilidade programática (Ayres et al., 2003), em relação à oferta de serviços na APS, há a necessidade de criação de novas técnicas comunicativas nos serviços de saúde, que relacionem práticas protetivas contra a infecção pelo HIV relacionadas a afetos alegres e superem afetos tristes relacionados ao estigma e à discriminação. "É impulsionados pelos afetos que decidimos se algo é bom e que determinada ação deve ser evitada. Uma ideia, uma ação ou um desejo mudam apenas com uma emoção mais forte." (Sawaia, 2003, p.59)

Pedidos de Teste Anti-HIV para População Geral e para "Populações Vulneráveis"

Além dos casos previstos nos programas de tuberculose e pré-natal, alguns profissionais mencionam pedir o exame de HIV quando realiza exames de rotina para pacientes:

"Vamos supor, vem uma pessoa jovem de 25, 20 anos, sem nenhuma queixa e quer fazer um check-up. A rigor, se a pessoa não é obesa, não tem problema nenhum, você não nota nada que você deva, você pensa: 'Tá, uma pessoa saudável e quer saber minha opinião sobre a saúde dela, acho que é um bom momento pra oferecer o exame de aids.' Se existe algum exame importante pra ser feito naquele momento, se é uma pessoa que tem atividade sexual e tudo o mais, que já teve, pelo menos, acho que é um bom momento pra oferecer. (...) Então vamos supor, uma consulta de hipertenso. É uma consulta pra saber o controle da hipertensão, uso de remédio e o paciente não tem nenhuma outra demanda. Aí você: 'Tá, tá na época de fazer exames de rotina.' Aí pega lá os bloquinhos pra preencher e tem no meio lá a 
bolinha do HIV. Dai eu falo assim: 'O que o senhor acha de fazer uma sorologia junto, já que você vai fazer exame de sangue, o que você acharia de fazer uma sorologia pra doença sexualmente transmissível?' Isso é um momento em que não houve um gancho. O gancho fui buscar na hora de fazer o exame." (Médico 1 b de São Paulo)

Este médico relatou que oferece tranquilamente o teste anti-HIV para todos os pacientes, como parte dos exames de rotina e deixa aberta a possibilidade de eles aceitarem ou recusarem.

No entanto, o teste anti-HIV pode não ser realizado na APS por questões relacionadas à organização da rede de serviços.

Os profissionais disseram que poucos pacientes buscam a UBS especialmente para fazer o teste de HIV. Geralmente, quando querem fazer o exame de HIV, costumam procurar diretamente o serviço especializado em DST/aids, tanto em São Paulo, como em Fortaleza.

"Aqui tem um serviço muito estruturado, que é o hospital [hospital especializado em DST/aids e hepatites virais], pra paciente portador de HIV, então os pacientes vão muito pra lá, direto, sabe, assim, de suspeita, de qualquer coisa, eles procuram direto o hospital, porque ele é o hospital do paciente com HIV, entendeu?" (Médica 2a de Fortaleza)

"Ou a gente marca pro clínico, ou a gente encaminha, porque lá no [serviço especializado em DST/aids] existe o grupo de acolhimento e acho que é muito mais fácil. E tem o teste rápido, a gente não tem o teste rápido, sorologia pra HIV, que é feito na hora." (Enfermeira 2b de São Paulo).

Usuários que buscam a UBS especialmente para se testarem podem ser encaminhados para serviços especializados, pela maior rapidez e recursos, inclusive com a realização do Teste Rápido anti-HIV, que no momento não estava disponível para as UBS estudadas, e pela maior variedade de profissionais de saúde, como psicólogos e a realização de grupos. Esta constatação condiz com avaliações estruturadas e qualitativas realizadas em sete estados brasileiros sobre serviços especializados para atendimento de pessoas vivendo com HIV e aids sobre sua qualidade diferenciada em relação a outros serviços de saúde, por sua estrutura física e disponibilidade de profissionais de saúde (Nemes et al., 2004), condições que 
favoreceriam a prática do aconselhamento. Entretanto, mesmo sob estas condições, pode haver uma dificuldade de escuta sobre as necessidades dos pacientes e os profissionais podem realizar o aconselhamento restringindo-se a roteiros préestabelecidos de anamnese e ao repasse de informações sobre a infecção e sua prevenção, especialmente quando os profissionais temem lidar com situações inesperadas e não têm com quem discutir sobre sua atuação, segundo avaliação qualitativa com observações de campo e entrevistas semiestruturadas em serviços especializados em DST/aids em seis estados brasileiros (Filgueiras e Deslandes, 1999).

Talvez seja, como a enfermeira relatou, "mais tranquilo" para o paciente ser encaminhado para um serviço especializado em DST/aids por ser mais estruturado e ter maior disponibilidade de recursos, mas existem também importantes questões relacionadas a valores ético-políticos implicadas no pedido de teste anti-HIV. Segundo alguns relatos dos profissionais de saúde, estes oferecem o teste somente em casos previstos em protocolos do Ministério da Saúde, como pré-natal e tuberculose, pois o oferecimento do teste em outros casos parece ser considerado invasivo.

"Como eu peço muito na rotina, eu não chego prum paciente do nada e digo: 'Ei, vamos fazer o exame anti-HIV?' Tá entendendo? Geralmente eu peço seguindo uma rotina, uma coisa que o paciente já sabe que tem que fazer, já sabe que existe. No caso da tuberculose, quando eu tenho que pedir, geralmente eu explico: 'Ó, vamos fazer o anti-HIV, a gente sempre pede, que é uma coisa que as pessoas às vezes acham que você tá pedindo: 'porque eu sou magro', 'porque eu sou negro', 'porque eu sou, eu ando meio assim e a senhora acha que eu sou gay', 'a senhora tá achando alguma coisa de mim'. A primeira coisa que eu digo é que é um exame de rotina, eu não tô pedindo pra ele, tô pedindo, porque ele é um paciente que tem tuberculose." (Médica 2a de Fortaleza)

$\mathrm{O}$ relato de uma enfermeira mostra que o teste anti-HIV pode não ser oferecido para as mulheres que não estejam grávidas e que questões morais e religiosas podem impedir o fornecimento do exame.

"O que eu percebo é que aquelas pacientes que são evangélicas mesmo, a gente nem aborda. Religião tem diferença, por quê? As pacientes evangélicas 
geralmente não têm relação antes do casamento. (...) Então a gente vai abordar outras questões, porque elas nem têm relação." (Enfermeira 1 a de São Paulo)

Alguns profissionais demonstraram claramente um estranhamento acerca do pedido se não houver um diagnóstico de DST ou uma situação de risco de infecção pelo HIV explicitada pelo paciente e por isso preferem não oferecer o teste anti-HIV de maneira geral.

"As pessoas procuram mesmo aqui é pra, eles querem fazer o que chamam de um 'check-up' geral (...). Aí nesse caso a gente solicita os básicos mesmo, hemograma, glicemia, colesterol total. Aí em alguns casos a gente vê, nota algum, algum comportamento que possa, enfim, durante a consulta, que a gente acha que a pessoa precisa fazer outros exames, a gente oferta os exames anti-HIV, VDRL, pra hepatite, todos esses. '” (Médico 2a de Fortaleza)

"É estranho você sugerir pra alguém, porque sempre tá ligado a uma exposição de risco, então você olhar pra cara da pessoa e por nenhum motivo você dizer isso? Quer fazer o anti-HIV? Você não quer não? Não tem sentido. Eu acho que é pessoal também. Cada um quer cuidar da sua saúde. Eu acho que tá tão difundido, assim, que existe a doença, que ela tá aí, existe um exame disponível em todo canto, onde chega, você faz, em qualquer posto de saúde você chega e esse exame é solicitado, que não tem sentido a gente estar coagindo ou, sei lá, convencendo ninguém a fazer o exame, é pessoal. Eu não obrigo ninguém a fazer o exame de diabetes. Ninguém tem a obrigação de saber." (Médica 2a de Fortaleza)

A médica, por essa fala, pressupunha que todos já tivessem informação sobre a testagem anti-HIV e se sentissem à vontade para pedi-lo, não se vendo na responsabilidade de quem deve disseminar estas informações e checar sua existência e pertinência. Ela associou "oferecer" a "coagir", possivelmente pelo receio associado ao teste de HIV. Esta fala ilustra as dificuldades relacionadas ao exame anti-HIV, relacionadas, historicamente, aos chamados "grupos de risco" e ao consequente estigma e discriminação daqueles identificados com este grupo. Um exemplo de comportamento que parte dos profissionais consideraram necessários para a oferta do exame anti-HIV é a infidelidade e relações sexuais com parceiros eventuais desde que espontaneamente relatados. Destacamos que, dos casos relatados, os usuários se sentiram à vontade para expor temas íntimos como 
desconfiança do parceiro e múltiplas parcerias, pela confiança que depositavam nos profissionais e abertura para o diálogo a partir de programas do serviço.

Estes relatos indicam dificuldades para conversar sobre alguns temas relacionados a valores ético-políticos como a sexualidade e as relações de gênero, que podem ser dificultadores para o processo de testagem anti-HIV. Uma das profissionais entrevistadas neste estudo relata uma projeção de seus valores, que pressupõe que as usuárias compartilhem, o que resulta em uma dificuldade para ação. Imaginando a possibilidade de ter de comunicar um resultado positivo para uma gestante, projeta a dor que sentiria ao ter um relacionamento em que a infidelidade poderia estar presente:

"Na minha opinião, ainda que eu oriente a pessoa dizendo o que é a doença, como você adquiriu, que a gente tem condições de ajudá-la, no tratamento da saúde dela e do filho dela, mesmo eu explicando tudo isso, eu ainda vou, caso o resultado venha a ser positivo, mesmo sem ser a intenção, eu desestruturo a mulher, a família, como um todo. Porque eu não sei se a mulher quer saber. Vai que ela tenha ofilho, e se ela não soubesse, o filho dela morrer, ela nunca saiba porquê foi, ela ficou casada, nunca desconfiou do marido, ela não separou. E às vezes a gente fala isso, a mulher deixa de amar o companheiro, o companheiro não entende. Então até que ponto o aconselhamento é bom pra mulher. (...) O que eu questiono é a estrutura. Ainda que a gente tenha a referência e a contrarreferência bem-estabelecida e que seja fácil e rápida, tudo, mas eu faço juízo por mim, eu não iria querer saber. Vou ser bem sincera, eu não gostaria de saber." (Enfermeira 1b de Fortaleza)

A profissional, no entanto, coloca seus valores morais relacionados à infidelidade do parceiro e desestruturação de uma família à frente de seu dever profissional, qual seja, realizar o aconselhamento com todas as gestantes, e perguntar a ela se ela quer saber. O diálogo e abertura para o tema são necessários para que as mulheres possam realizar escolhas que favoreçam sua felicidade e bem-estar, de maneira emancipada. Privar as mulheres da possibilidade de escolha é uma violação de seu direito à saúde.

Estudo (D’Oliveira e Schraiber, 1999) em uma UBS de São Paulo analisou a observação de 16 grupos voltados para mulheres, totalizando 115 mulheres, coordenados por profissionais de saúde também mulheres. Segundo este estudo 
(D’Oliveira e Schraiber, 1999), as profissionais "compartilham de alguma maneira a experiência de ser mulher na cidade de São Paulo", expostas às mesmas normas e expectativas sociais hegemônicas para os gêneros. As profissionais oscilaram entre o discurso epidemiológico de recomendar o uso do preservativo em todas as relações e a identificação com os valores morais das usuárias e sua dificuldade em negociá-lo com seus respectivos parceiros.

Acrescentaríamos que, assim como é difícil prescrever o uso do preservativo para mulheres adultas casadas, também é difícil oferecer o teste anti-HIV, porque ambas as ações remetem ao imaginário sobre sexualidade e infidelidade, assuntos que podem ser considerados invasivos e desconfortáveis. Compreendemos que esta dificuldade em discutir questões de gênero pode refletir uma carência na formação dos profissionais em se voltar para aspectos sociais e afetivos, além dos aspectos biomédicos da assistência à saúde.

Consideramos que a afetividade pode fazer parte da técnica do trabalho e usada para melhorar os atendimentos, para compreender o que o outro mobiliza em si e informar e sensibilizar sobre a atitude mais adequada a ser realizada no momento. Quando a afetividade é ignorada, pode se transformar em atuações, através de projeção dos próprios valores dos profissionais e uma dificuldade de reconhecimento da subjetividade do usuário.

Obermeyer e Osborn (2007), em revisão citada anteriormente, apresentam uma revisão de estudos internacionais que descrevem algumas dificuldades emocionais dos profissionais de saúde em relação ao teste anti-HIV: estes podem temer a infecção pelo HIV, e sentir-se impotentes, pessimistas e inseguros sobre sua capacidade de cuidar de alguém cujo resultado dê positivo.

Por considerarem o teste invasivo e temerem discriminar usuários, os profissionais de saúde podem perder a oportunidade de abrir espaços para conversar sobre o teste anti-HIV e fazer com que os usuários se sintam à vontade para discutir sobre formas de diminuir seu risco para HIV, inclusive nos próprios casos realizados por protocolos, o que diminui a potência dos encontros.

Observamos que há outras questões relacionadas a valores ético-políticos relacionadas à prática de testagem anti-HIV e aconselhamento na Atenção Primária à 
Saúde, que dizem respeito às "relações intergeracionais" e ao estigma relacionado a determinados grupos.

Uma explicação oferecida por alguns profissionais para não oferecer o teste anti-HIV para a população em geral é evitar o estigma e discriminação sobre alguns usuários, como considerar que são "magros" ou "gays". Entretanto, para alguns grupos, não é necessária a menção de infidelidade e parcerias eventuais para que seja ofertado o pedido de teste anti-HIV, já que são grupos que os profissionais pressupõe que tenham maior risco: adolescentes, portadores de DST, trabalhadoras do sexo, alcoolistas, usuários de drogas e crianças em abrigo. Ao não se sentirem à vontade para oferecer para todos os usuários, alguns profissionais de saúde priorizam a oferta de teste anti-HIV para grupos marginalizados, considerados de maior risco ou vulnerabilidade pelos profissionais e oferecem tratamento especial, o que pode aumentar a discriminação sobre estes, como detalhado a seguir.

Sobre as questões "intergeracionais" presentes, no caso dos adolescentes, os profissionais parecem entender que eles já esperam e querem a oferta da testagem anti-HIV. Talvez por esta razão, seja uma prática mais comum oferecê-lo para os jovens, geralmente primeiros e principais casos lembrados nos quais houve conversas sobre DST em consultas individuais e em palestras.

"Por exemplo, não dá pra fazer isso [aconselhamento, pela falta de tempo, mencionada em outro momento da entrevista], realmente a gente não faz isso em toda consulta, mas no planejamento familiar, tá entendendo? Em consultas com os adolescentes, a gente acaba pegando mais adolescentes, porque, na verdade, era pra ser oferecido pra todos, né?" (Médica 2 b de Fortaleza)

Destacamos que na fala desta médica, esta considera que a oferta do teste anti-HIV deveria ser feita para todos, porém, no cotidiano, oferece para os jovens. Nesse caso, embora pudesse ser relatado como fator dificultador para o oferecimento do teste anti-HIV a falta de tempo durante as consultas, chama a atenção que para os jovens é comum o oferecimento do teste anti-HIV e para os adultos não.

“Quando a gente faz palestras com adolescentes, quando a gente faz palestra com gestantes, que são grupos que normalmente a gente faz um trabalho, a gente aborda isso." (Médico 1b de Fortaleza) 
"Então, o que a gente faz aqui é assim, a gente aborda, eu abordo isso na consulta com os adolescentes, né? E sempre que aparece algum usuário, tô no acolhimento e aparece, o usuário vem com alguma DST, eu ofereço o exame antiHIV." (Enfermeira 1 a de São Paulo)

"Individualmente eu faço, sempre que tem uma oportunidade de conversa com adolescente, por exemplo, eu encaixo. (...) Ah, por exemplo, vamos supor, uma moça de 12, 13 anos, começou a menstruar. Eu aproveito pra falar sobre gestação. Gestação não vem sem atividade sexual. Então a gente encaixa as duas coisas e fala, abrir a porta pra ela saber onde ela pode buscar um método anticoncepcional, conversar sobre o risco de pegar uma doença." (Médico 1 a de São Paulo)

Estas falas são ilustrativas da associação entre vida sexual, juventude e decorrências disso, como gravidez e DST.

Este discurso é respaldado por um manual produzido pelo Ministério da Saúde, já citado, sobre o aconselhamento na Atenção Básica, que apresenta uma seção específica sobre recomendações para jovens:

Orientar sobre sexo seguro inclui abordar a prevenção da gravidez precoce e não programada, como uma prática a ser assumida por ambos os sexos, uma vez que tal ocorrência tem conseqüências para os homens e mulheres. (Brasil, 2004a)

O oferecimento do teste anti-HIV para os jovens é condizente com alguns dados epidemiológicos, pois se estima que a prevalência do HIV na população de 17 a 20 anos tenha passado de 0,09 a 0,12\%, no período de 1999 a 2009. Além disso, as ações nos serviços de saúde assumem grande importância para abarcar os jovens que não frequentam a escola, pois, quanto menor a escolaridade, maior o percentual de infectados pelo HIV. A prevalência entre os meninos com ensino fundamental incompleto é de $0,17 \%$ e entre os que têm ensino fundamental completo é de $0,10 \%{ }^{6}$

Os profissionais podem considerar um dever conversar com os jovens sobre sexualidade para educá-los, por estarem iniciando a vida sexual e ser mais fácil educá-los do que em outras faixas etárias.

\footnotetext{
${ }^{6}$ Brasil. Ministério da Saúde. Departamento de DST/Aids e Hepatites Virais. Assessoria de Imprensa. Cai a transmissão de HIV da mãe par ao filho. Em jovens, tende a crescer. 01 de dezembro de 2010.
} 
Entretanto, observamos que oferecer o teste anti-HIV para os jovens não deveria excluir pedi-lo para a população em geral, pois, como relatado anteriormente, a maior prevalência está em adultos de 30 a 49 anos.

Pelos relatos dos profissionais, geralmente os adultos e idosos são abarcados no pedido de teste anti-HIV somente quando se encaixam em protocolos presentes em programas do serviço, como pré-natal e tuberculose. Esta informação é preocupante, porque a faixa etária de 30 a 49 anos apresenta a maior incidência de aids (Brasil, 2010b). A maior proporção dos casos de aids se encontra entre os 40 e 49 anos de idade. Ainda, verifica-se um aumento importante dos casos de aids em idosos, em ambos os sexos, que passaram de 394 casos em 1999 para 938 casos em 2009 no sexo masculino, e, no feminino, de 191 casos em 1999 para 685 casos em 2009. A faixa etária de 35 a 39 anos exibe a maior taxa de detecção do país, 46,7 casos por 100.000 habitantes em 2009. (Brasil, 2010a)

A preocupação relativamente exacerbada sobre os jovens em relação ao HIV, comparando-se com outras faixas etárias, não se justifica por dados epidemiológicos, e sim por um imaginário social, veiculado pela mídia e pela literatura psicológica de abordagem essencialista, do "jovem-problema", irresponsável e que não consegue cuidar de sua saúde, como também foi observado no trabalho de Bellenzani (2008), em relatos de profissionais de saúde do Rio de Janeiro, que relacionaram o adolescente a ser "onipotente" e "sem juízo".

Um estudo de Paiva et al. (2008), com amostras representativas da população urbana brasileira em entrevistas em inquérito domiciliar comparando duas pesquisas, realizadas em 1998 e 2005, com 670 jovens (16 a 19 anos) sexualmente ativos, indicou que houve aumento do uso do preservativo na primeira relação em relações estáveis (48,5\% em 1998 vs. 67,7\% em 2005) e casuais (47,2\% em 1998 vs. 62,6\% em 2005). Estudo de Berquó et al. (2008), já citado, relacionada à mesma pesquisa, comparando os jovens a outras faixas etárias, indicou que jovens de 16 a 24 anos relataram maior uso de preservativo, em comparação com outras faixas etárias $(59,2 \%)$, principalmente com parcerias eventuais.

Outro estudo de Paiva et al. (2003), realizado com dados do IBGE, a pedido do Programa de DST/aids do Ministério da Saúde, com 1.298 entrevistas com pessoas classificadas como sexualmente ativas, em todo o território nacional, traz 
como resultado que os jovens são os que mais usam preservativo na primeira relação sexual e mais usam preservativo de maneira consistente, inclusive com parceiros fixos, em comparação com outras faixas etárias. O uso de preservativo na primeira relação chega a 54,6\% entre os mais jovens, no momento da entrevista, entre 14 e 25 anos de idade, comparado com a faixa etária seguinte, de 26 a 40 anos (20,7\%) e nos segmentos mais velhos (12,8\% de 41 a 55 anos e 11,8\% acima de 56 anos). Estão entre eles tanto os que mais usam a camisinha de forma consistente $(28,3 \%$, sendo que $15,2 \%$ declaram fazê-lo mesmo estando em relação estável exclusiva), comparando com as faixas etárias seguintes (de 26 a 40 anos, 12,6\%, de 41 a 55 anos, 9\% e, 56 anos ou mais, 2,7\%). Esses dados não devem levar a uma despreocupação com os jovens, como relatado anteriormente, pois também os jovens são desprotegidos ao não usarem preservativo tendo mais de um parceiro, 17,4\%, sendo que 5,2\% usam em algumas relações e 12,2\% nunca usam.

Novamente chamamos a atenção de que a prática do aconselhamento implica em conversas singulares para cada caso e não uma padronização fixa, baseada em estereótipos.

Outra questão relacionada ao processo de testagem anti-HIV é o estigma relacionado a determinados grupos, mais especificamente, trabalhadores do sexo e homossexuais, com os quais os entrevistados consideram que a conversa sobre sexo seria necessária e esperada. Estes grupos também foram citados como população para a qual os profissionais de saúde estão predispostos a oferecerem o teste antiHIV.

Pelos relatos, os profissionais de saúde se sentem mais à vontade para discutir sobre prevenção às DST/aids com as mulheres trabalhadoras do sexo e lhes oferecer o teste anti-HIV, do que com outras mulheres, especialmente aquelas com mais de 25 anos, com relacionamento monogâmico.

"Ela deixou de ser [trabalhadora do sexo], ela tem por volta de 30 anos. E eu deixei aberto pra ela: 'Toda vez que você quiser fazer exame de HIV, é só você me pedir, que eu te dou o pedido.' Mas eu também deixei combinado com ela, conversei sobre prevenção e tudo o mais. E deixei combinado com ela que, caso a gente percebesse que ela tá ficando muito preocupada com isso, a gente teria uma 
nova conversa sobre o porquê ela está também precisando fazer o exame toda hora. Claro, ela tá se pondo em risco." (Médico 1b de São Paulo)

Pelos relatos, espera-se que as mulheres trabalhadoras do sexo também se sintam mais à vontade para conversar e tirar suas dúvidas sobre DST/aids e demandar sua testagem do que outras usuárias.

Uma médica de São Paulo cita como exemplo o caso de uma trabalhadora do sexo que realizou o teste para o pré-natal e, que, segundo ela, apesar da própria paciente esperar, de certa maneira, que o resultado desse positivo para HIV, por saber que havia se exposto a situações de risco, quando isso realmente aconteceu, sofreu muito.

"Eu tive a última paciente com HIV o ano passado. HIV, ela também não sabia. Mas ela era, ela é profissional do sexo. Ela falou que tinha esse risco, às vezes rompe camisinha. Ela falou: 'Eu sabia que um dia eu podia pegar.' Quer dizer, ela tava melhor preparada. Mesmo assim, depois ela desabou e é muito difícil. (...) Pra mim é angustiante, falar que não [Riso.]. É muito difícil." (médica 2 de São Paulo)

Uma outra expectativa dos profissionais de saúde, expressa por este relato, parece ser de que estas sofram menos por já esperarem um resultado positivo para HIV, por terem consciência de situações de risco que passam, por isso talvez seja mais fácil para o profissional oferecer o teste anti-HIV. Esta expectativa remete ao estigma, analisado por Goffmann (2008), construído socialmente, de redução da pessoa a apenas uma característica sua e a associação a uma culpa que carregaria por seus comportamentos, resultando em uma dificuldade em considerá-la de maneira inteira, com sofrimentos, como qualquer outra pessoa.

Os profissionais referiram ter maior facilidade em apresentar um olhar mais atento a sua saúde e maior abertura na conversa para abordar temas que levem à testagem anti-HIV com homens que aparentem ser homossexuais, por seu jeito afeminado de falar, de se vestir e de se portar.

Foram relatados dois casos de pedidos de teste anti-HIV para rapazes homossexuais em UBS de São Paulo. No primeiro caso, durante consulta com este médico mencionado, o rapaz relatou se relacionar com trabalhadores do sexo. Este caso lembrado não ocorreu na UBS na qual ele trabalhava no momento da pesquisa, 
e sim em UBS anterior, e será usado aqui como ilustração de uma possiblidade para atenção básica.

No segundo, uma ACS associou o grande emagrecimento e indisposição com a possibilidade de adoecimento por aids.

Nesse primeiro caso, o médico ressalva de que não são apenas homossexuais que pegam HIV e tem consciência sobre seus próprios "preconceitos":

"Lembro de casos em que eu por preconceito, achei que a pessoa fosse homossexual e por causa desse preconceito ofereci o exame de HIV. Não achando que só homossexual pega aids, pelo amor de Deus, não é isso que eu quero dizer (...) Eu nunca falei pro cara: 'Você é gay, só porque você tá com camisa rosa.' Não é isso, mas eu tento, às vezes eu me sinto à vontade, às vezes o paciente acaba te falando, mas você espera outros momentos pra que aquilo saia. (...) Eu lembro de um caso sim. Quando eu tava no posto, antes de fazer residência. Era um moço, um rapaz de 20 anos que tava tendo umas crises de ansiedade e ele pra mim parecia ser homossexual e eu como intervenção na consulta, falei: 'Você tem umas crises de ansiedade. ', não sei o quê. Acho que isso muitas vezes é uma coisa que tem dentro de você, que você tem um desejo de contar pras pessoas, desejo de falar e você tá preso e não consegue falar. E ele falou: 'É verdade.' Ele falou: 'Sou homossexual.' (...)Foi uma intervenção boa, mas nem sempre dá certo. Às vezes você fala isso pra um cara que você acha que é e ele não vai te dizer. Ou o cara pode ser homossexual e não parecer também, aí... (...) Porque nessa consulta especificamente porque ele me falou que tava transando com pessoas que ele encontrava à beira do cemitério, que eram profissionais do sexo também, aí eu... (...) Ele saía com [profissionais do sexo], porque como ele era envergonhado, de não querer que ninguém soubesse, ele não saía dentro do círculo social dele, ele procurava pessoas pra que ele tivesse uma atividade sexual escondida. Então ele me contou isso também na consulta, então eu imaginei que valia a pena ele fazer o exame de HIV. Ele fez, fez.(...) Aí eu não acompanhei por muito tempo, porque eu saí de lá, então não sei." (Médico $1 \mathrm{~b}$ de São Paulo)

No segundo caso mencionado, houve uma atuação conjunta entre uma enfermeira e uma agente comunitária de saúde, na UBS em São Paulo, embora não estivesse explícito para a ACS o motivo da atuação conjunta. A enfermeira coloca 
que conversou sobre a importância do sigilo, mas relata que pela importância dada ao caso, a ACS certamente deduziria que se tratasse de um diagnóstico positivo para HIV.

Outro ponto que destacamos deste caso é o pedido do próprio paciente para ser atendido em um outro serviço, distante de onde mora, para manter o sigilo sobre seu tratamento. Ainda sobre o medo do estigma e da discriminação, destacam-se o manejo e a flexibilidade da equipe para atender o paciente conforme suas necessidades, comunicando o resultado positivo para HIV em local não usual.

"Quando eu era enfermeira, a gente teve um diagnóstico de HIV positivo. (...) A primeira vez que ele veio no posto foi no acolhimento. Ele veio no posto, ele tava com uma queixa, ele já tava com sintoma, sintomático. Tava com diarreia. E aí diarreia, diarreia, diarreia. A médica pediu, perguntou se ele queria fazer, ele topou e veio. Ele já tava com sintoma, no acolhimento. (...) Foi feito o diagnóstico e essa pessoa, ela pediu. A gente encaminha pro [serviço especializado em DST/aids]. Quem acompanha mesmo é a atenção secundária. No nosso caso, o [serviço especializado em DST/aids]. E ele pediu, justamente, sem saber, ele pediu pra tratar em outro lugar, porque ele não queria ficar aqui, porque ele conhece as pessoas. E ele não queria uma exposição. Isso foi uma coisa que foi muito marcante pra mim. 'Quero ir pra um lugar que ninguém me conheça. Que eu não quero, eu não tô preparado pra contar pra ninguém ainda. E eu não quero ver ninguém.' Foi interessante esse caso, porque esse, quem deu esse resultado foi a médica. Mas ele não, assim, ele recebeu o resultado, mas a gente brinca 'não caiu a ficha'. Não foi pro [serviço especializado em DST/aids]. Passou uns dias, ele não foi. Ela pediu pra agente comunitária perguntar e aí ela foi, falou: 'Ó, ele não foi.' (...) Aí a gente, eu pedi pra conversar com ele e ele pediu pra conversar comigo lá na pracinha. Por que isso? Ele não queria que a gente fosse na casa dele, não queria vir no posto. E aí eu conversei com ele bastante, eu não só uma vez, mas mais de uma vez, na pracinha. Numa pracinha que tem escondidinha. Então tem isso também. É uma, a gente vive, trabalha com comunidades que qualquer coisa espalha, vira fofoca $e$ espalha muito rápido. Eé um inferno na vida das pessoas. As pessoas não respeitam privacidade. Isso é uma coisa que a gente tem que ter muito cuidado, muito cuidado. Tanto que quando eu fui tratar com isso, a agente comunitária não sabia 
exatamente, mas as pessoas sacam também. Ela sacou que era uma coisa séria, pela nossa preocupação. E eu coloquei pra ela a importância do sigilo. Eu não falei o que era. Mas ela sacou. As pessoas sacam pelo jeito da gente, como a gente lida. Por que alguns diagnósticos a gente fala abertamente e outros não? Eu acho isso. E foi difícil. Essa coisa da privacidade é um problema do PSF. Todo mundo se conhece." (Gerente 1 a de São Paulo)

Tivemos oportunidade de entrevistar a ACS que atuou neste caso e conhecer seu ponto de vista. Destacamos de sua narrativa seu acolhimento, como descreve Teixeira (2003a, b), ao ampliar possibilidades de trânsito do paciente pelo serviço de saúde. Era um paciente de difícil acesso para o serviço, que talvez tivesse demorado ainda mais tempo para procurá-lo. A ACS agiu de maneira preocupada, mesmo que coercitiva, seguindo sua intuição pelo imaginário associado aos chamados "grupos de risco", imaginário presente na sociedade.

"Esse paciente da minha área, ele muito difícil pra conseguir fazer os exames, na época, porque eu tinha uma leve desconfiança por ele ser gay, né? E eu achava que ele tava emagrecendo muito. Cheguei e falei pra ele: 'E aí, tá na hora de você fazer uns exames, tal. Faz tempo que você não passa com o médico.' Ele: 'Eu vou, eu vou.' Uma hora ele sumia, ia pra casa de algum parente fora da minha área, ficava uma semana lá e depois aparecia de novo e eu falava: 'Você já fez os exames?' 'Não.' Aí eu peguei, insisti, até que ele veio fazer." (ACS 1 de São Paulo)

A ACS falou abertamente que conhecia o resultado dos exames e o acompanhava, como parte da equipe de profissionais de saúde do serviço, o que remete às tensões do papel de ACS, pois os profissionais relatam não comunicar os motivos para convocar os pacientes, por seu lugar delicado de ser ao mesmo tempo membro da comunidade e profissional de saúde.

As tensões entre os ACS e outros profissionais de saúde são apontadas em estudo cartográfico em Itabuna, Bahia (Ferreira et al., 2009). Tratou-se de um estudo de caso, em uma unidade saúde da família, através de observação direta realizada pontualmente, durante uma semana, acompanhado os ACS no território e domicílio, entrevista semiestruturada e grupo focal realizado em duas sessões. Apesar das ações cuidadoras e criativas dos ACS, há dificuldades de reconhecimento de sua capacidade técnica de trabalho. A equipe permanece territorializada no modelo 
centrado em procedimentos, "deslegitima e questiona a ação do ACS naquilo que ele inova." (Ferreira et al., 2009, p. 905)

No presente relato, a ACS demonstra ter um cuidado com o manejo do paciente, por sua sensibilidade e preocupação com o sigilo de informações. Novamente, mostra que seu papel foi importante para comunicação de resultado.

"Aí pegou a primeira amostra e já deu positivo. Daí nós repetimos e foi difícil, porque quando constatou, ninguém falou praticamente pra ele que já tinha dado, a gente pega e aguarda uma segunda amostra. E eu fiquei insistindo pra ele insistir os exames e ele falava assim: 'Não precisa, eu já fiz os exames.' Eu falei: 'Não, mas é bom repetir, porque a sua amostra não foi suficiente pra poder fazer o exame direito, acho que o sangue coagulou.' Eu dei uma desculpa pra ele vir repetir e não falar pra ele que deu na primeira amostra, pra ele não ficar assustado. Aí insisti, demorou mais de um mês pra ele vir repetir, até que ele veio, quando chegou o resultado, foi chamado ele, a enfermeira chamou. E como ele não queria que fosse na casa dele, porque a mãe dele não podia saber, os parentes. Aí eu até marquei na minha casa, mas como eu tinha um filho em casa, não queria que ele escutasse também. Aí nós marcamos num lugar reservado, fora. Aí ele foi, a enfermeira conversou com ele, explicou pra ele tudo direitinho, o que tinha que fazer, onde tinha que ser acompanhado pra tomar os remédios tudo." (ACS 1 de São Paulo)

A disponibilidade de atenção ao paciente, mesclada com sua vigilância à saúde, incentivaram o paciente a começar a buscar tratamento, embora tardiamente, quando já apresentava sintomas de aids.

Nesse caso, houve uma limitação da autonomia do paciente durante o atendimento, por dificuldade em lidar com valores e emoções, quando a ACS não ofereceu a informação verdadeira para a repetição do exame, demonstrando receio de o paciente ficar "assustado".

Outro grupo também marcado pelo estigma para o qual os profissionais se predispõem a oferecer o pedido do teste anti-HIV é de alcoolistas e usuários de drogas, como possível de acontecer sem constrangimento de ambas as partes.

"Tem vários pacientes alcoolistas, usuários de drogas, que têm vários riscos, além de tudo [além dos casos previstos em protocolos, como tuberculose], a gente tem que pedir o anti-HIV de qualquer jeito." (Médica 2a de Fortaleza) 
Um manual do Ministério da Saúde (Brasil, 2004a), já mencionado, atenta para situações que demandem o oferecimento do teste anti-HIV: sexo sem preservativo; uso de drogas; e DST, e destacam especialmente os jovens:

Perguntar sobre o consumo de álcool e outras drogas deve fazer parte da rotina dos profissionais de saúde. As orientações sobre a diminuição do uso do preservativo e os riscos no volante sob o efeito do álcool são formas de se levantar os episódios de abuso de drogas presentes nesta faixa etária. (p. 17)

Um último grupo marcado pelo estigma para o qual os profissionais se predispõem a oferecer o pedido do teste anti-HIV relatado foi de crianças em situação de abrigo. Foram relatados poucos casos de pedido de teste anti-HIV para este grupo por uma médica de São Paulo, em uma UBS na qual trabalhou anteriormente, na mesma região da cidade, próxima a uma casa de apoio. As crianças eram testadas ao chegarem nesta casa. Embora esta experiência não tenha ocorrido na UBS na qual trabalhava, campo de estudo, ela foi considerada relevante para pensar possibilidades de testagem na atenção primária. No caso, a médica e os profissionais do abrigo consideravam que as crianças estavam numa situação de vulnerabilidade social, e por isso eram consideradas em risco para infecção pelo HIV.

"E muitas dessas crianças não tinham nem história. História assim, tinha criança que foi abandonada, mas não sabia nada, e mesmo as crianças vítimas de maus tratos, os funcionários não eram muito sabedores do que tinha acontecido. Tinha muito crianças filhas de pais presos, então ficava no abrigo. Eu pedia de triagem, mas graças a Deus, no período que eu tive lá, não tive nenhum positivo." (Médica 2b de São Paulo)

Os pais, segundo esta médica, apenas visitavam as crianças, que viviam sob internato e perdiam sua guarda, sendo seus responsáveis legais os funcionários do abrigo. No entanto, os pais poderiam sofrer repercussões sobre um resultado positivo para HIV nas crianças, como sentimentos de tristeza e a suspeita de que eles próprios estivessem infectados pelo HIV. As crianças eram acompanhadas em serviços especializados em DST/aids, quando o resultado fosse positivo.

O Ministério da Saúde destaca que a testagem não deve ser compulsória para "crianças e adolescentes sob medida protetiva de abrigo ou adolescentes em 
cumprimento de medida socioeducativa" (Brasil, 2004b, p.41). Neste documento, é relembrada a lembrar a Resolução do CFM 1665/2003, no art. 4 : "É vedada a realização compulsória de sorologia para HIV" (Brasil, 2004b, p.42).

A médica agiu contra esta recomendação, porque testava compulsoriamente crianças morando em abrigo.

Segundo este mesmo documento do Ministério da saúde, a testagem anti-HIV é indicada para:

bebê nascido de mãe sabidamente soropositiva ou com suspeita desse diagnóstico - com o consentimento dos responsáveis legais; (...) Para crianças e adolescentes portadores de DST e/ou usuários de drogas injetáveis, ou que tenham práticas de risco para o HIV (Brasil, 2004b, p. $39)$.

Segundo esta recomendação, poderia ser indicada a testagem anti-HIV em casos de suspeita do diagnóstico de soropositividade e, como mencionado por esta médica, os bebês eram "sem história", as crianças com "práticas de risco para o HIV", pois eram "vítimas de maus tratos" e "os funcionários não eram muito sabedores do que tinha acontecido". Nesses casos, o diagnóstico precoce possibilitaria o início do tratamento antirretroviral.

No entanto, a prática de testagem "compulsória" para crianças que moram em abrigo é contrária à outra recomendação deste mesmo documento, já que algumas destas crianças poderiam ser adotadas e este documento analisa que as crianças que tivessem resultado positivo para HIV poderiam ter a chance diminuída de serem adotadas e isso constituiria em uma prática discriminatória, que poderia prejudicar seu direito de ter uma família e uma moradia:

“O PN-DST/AIDS do Ministério da Saúde contraindica a realização aleatória de exames anti-HIV nesses casos, entendendo que esse tipo de testagem serve de argumento discriminatório. (...) Além disso, a possibilidade de exames falso-positivos em bebês, em função da presença de anticorpos maternos, poderia excluir muitas crianças saudáveis dessa possibilidade." (Brasil, 2004b, p.40).

Este é um outro caso no qual a recomendação do Ministério da Saúde e a prática dos serviços se desencontram. Não houve nenhum relato de supervisão ou responsabilização destes profissionais que descumpriram as orientações éticas do Ministério da Saúde, sendo possível que os profissionais as desconhecessem. 
A predisposição dos trabalhadores a fazerem o pedido do teste para os grupos citados, jovens, trabalhadores do sexo, homossexuais e "crianças de abrigo", vistos como potenciais infectados pelo HIV, está fortemente influenciada por pressuposições a respeito do risco de determinados grupos, que estão muito mais fundadas no imaginário social marcado pelo estigma do que em informações qualificadas sobre o risco efetivo destes grupos. Ao não oferecer a testagem anti-HIV de forma ampla na tentativa de não constranger ou ser invasivo, os profissionais acabam discriminando estes grupos, considerando que eles já "esperariam” o pedido e teriam maior facilidade de lidar com um eventual resultado positivo. Esta discriminação apresenta a vantagem de aumentar a possibilidade de diagnóstico precoce e cuidado à saúde para estes grupos e a desvantagem de aumentar sua marginalização e gerar a falsa despreocupação com a epidemia de quem não se encaixa neles. Nesta prática, os profissionais reproduzem o estigma da epidemia de aids, associado às "culpas de caráter individual, percebidas como vontade fraca, paixões tirânicas ou não naturais, crenças falsas e rígidas" (Goffmann, 2008, p. 12) e o discurso de grupos de risco, ainda que renovado.

Quando o exame anti-HIV se torna parte de uma rotina programática, leva a uma maior aceitação por parte dos usuários, por não levantar questionamentos morais sobre seu comportamento, conforme revisão de estudos já mencionada (Obermeyer e Osborn, 2007) realizados com: mulheres gestantes, quando faz parte de uma rotina do pré-natal e são informadas sobre os benefícios para o bebê, como em Botswana e Zimbabwe; pacientes hospitalizados nos Estados Unidos; pacientes de uma clínica de tuberculose em Kinshasa, Congo; de clínicas pediátricas na Zâmbia; de clínicas de tuberculose no Congo; de clínicas de DST, clínicas pediátricas e em maternidades na Uganda.

Tarantola e Gruskin (2007) destacam a importância da negociação individual com o paciente sobre a testagem anti-HIV, mesmo em casos de rotina, especialmente para as mulheres, levando em consideração o estigma, a discriminação e o risco de violência associados a um resultado HIV-positivo.

A dificuldade em realizar o aconselhamento na Atenção Básica foi relatada também por profissionais de saúde que compõem a Estratégia Saúde da Família em estudo já citado em duas UBS no Rio de Janeiro, associada a "receios e inseguranças 
por parte dos profissionais em abordar temáticas geradoras de sentimentos intensos nos próprios profissionais, além de remeterem ao universo de valores morais: fidelidade/infidelidade, vida/morte, dor/prazer, etc.” (Bellenzani, 2008, p. 225)

Os Encontros que Favorecem o Pedido do Teste Anti-HIV: Grupos e Atendimentos Clínicos que Abordam a Sexualidade

Foram identificadas questões relacionadas à organização do trabalho que favorecem o pedido do teste anti-HIV em casos não abrangidos pelos programas de pré-natal e tuberculose.

Quando questões sobre a sexualidade dos usuários faziam parte de protocolos do serviço de saúde, os profissionais de saúde consideravam a abordagem tranquila e não invasiva. Estes casos relatados nestas falas se referiam a programas do serviço com atividades específicas para homens, mulheres, adolescentes e idosos, como será detalhado a seguir.

Uma UBS em São Paulo apresentou atividades diferenciadas dentro do programa para a saúde da mulher, havia questionários como parte das consultas clínicas para as mulheres, que abordavam temas relacionados à sexualidade. Esta abertura de conversa permitia, segundo os profissionais entrevistados, que elas se sentissem à vontade para falar sobre o relacionamento com o parceiro, inclusive a suspeita sobre a infidelidade dos parceiros.

"Quando a gente faz a coleta do Papanicolau, a gente conversa sobre as questões de vida sexual. (...) Na consulta de saúde da mulher a gente aborda também $o$ relacionamento com o marido, então elas ficam às vezes receosas do comportamento do marido, aí elas pedem também o exame." (Enfermeira 1 a de São Paulo)

Assim também ocorreu em uma UBS com um programa para a saúde do homem, na qual há um questionário com perguntas sobre a vida sexual dos usuários, número de parceiros e uso de preservativo.

"Às vezes chegam homens aqui que eles relatam que têm relação extraconjugal e que não usam camisinha. E que desejariam fazer o exame. Então a 
gente: 'Então vamos fazer.' Porque no grupo de saúde do homem que eu trabalho na sexta-feira, a gente costuma preencher um questionário de saúde do homem. Aí nesse questionário vem dados assim: 'Idade, profissão, nível de escolaridade, queixas relacionadas à disfunção erétil, ejaculação precoce.' E tem uma parte do questionário que pergunta exatamente isso: 'O senhor tem parceiro fixo?' 'Usa camisinha?' Quando já diz que não, ou quando tem várias parceiras, ou parceiros, enfim, aí a gente oferta o exame, nesse de saúde do homem é até um pouco mais fácil, porque a gente já vai direcionado pra isso." (Médico 1 a de Fortaleza)

Pelo relato, haver questões sobre parceiros sexuais e uso do preservativo em um questionário padronizado, facilita a abordagem, pois introduz a questão na conversa, de forma rotineira, e enriquece a anamnese tradicional, sem parecer aos profissionais intromissão indevida ou questionamentos morais sobre o comportamento dos usuários. A mudança da técnica de conversa acaba por mudar o conteúdo do trabalho, desde que os profissionais sejam devidamente treinados e, preferencialmente, possam receber acompanhamento em suas ações.

Outro caso relatado se refere a um usuário idoso. Um grupo de idosos, coordenado por um enfermeiro facilitou a demanda pelo teste anti-HIV vinda deste usuário, exceção nos casos relatados, e também uma campanha de prevenção às DST/aids, voltada para idosos, demonstrando o importante papel da mídia e de investimentos em ações educativas para complementar as ações preventivas nas UBS. Ele se sentiu à vontade para pedir o teste anti-HIV para o enfermeiro que coordenava um grupo que discutia saúde dos idosos, em terapia comunitária, e realizava outras atividades educativas, como no dia da vacinação de idosos contra a gripe. Este grupo ocorria por iniciativa do próprio enfermeiro, como parte de uma formação nesse tipo de terapia. É possível também que o idoso se sentisse mais à vontade por ser um profissional homem, como relatado por outros profissionais.

"Bem interessante, uma vez eu tava no consultório, chegou um senhor preocupado, já até com Viagra no bolso, ele mostrou. Ele viu na TV, foi na época que teve aquela campanha do HIV em idoso, que agora mudou a questão da faixa etária. Ele ficou preocupado, assistiu a propaganda e viu, pediu conselho, porque ele tinha saído com uma menina mais nova e não tinha usado nada. 'Tudo bem, a 
gente solicita aqui, o senhor faz pra tirar esse peso na consciência, né?", (Enfermeiro 2 a de Fortaleza)

Chama a atenção, nesse caso, que o próprio idoso tenha tomado a iniciativa para pedir o teste anti-HIV e o enfermeiro considera que seria "para tirar seu peso na consciência", parecendo que ele achava improvável que alguém idoso pudesse ter um resultado positivo para HIV.

Estas iniciativas ampliam as possibilidades de atendimentos para homens que, por certo aspecto, apresentam maior autonomia para decidir sobre a realização da testagem anti-HIV e, por outro aspecto, recebem menos cuidados, com menor insistência do profissional de saúde sobre a testagem anti-HIV, diferentemente do que ocorre com as gestantes, quando há maior mobilização por parte dos profissionais.

\subsection{OS ENCONTROS PARA A COMUNICAÇÃO DE RESULTADO DE TESTE ANTI-HIV}

Uma questão relacionada à organização do trabalho relatada pelos entrevistados é que geralmente não são os mesmos profissionais que realizam o pedido e a comunicação do resultado de teste anti-HIV. No caso das gestantes, rotineiramente o primeiro pedido de teste anti-HIV é realizado pelo enfermeiro e a comunicação, pelo médico.

Ainda, há os casos atendidos nos momentos de atendimento "à demanda espontânea", casos não agendados, atendidos pelos profissionais disponíveis no momento, não necessariamente aqueles que atendem a área de abrangência do usuário, no caso das três UBS estudadas com a implantação da Estratégia Saúde da Família. Assim, os usuários podem ter o pedido do teste anti-HIV por um profissional fora de sua área de abrangência e receber o resultado pelo profissional da equipe de sua área, em consulta agendada.

Destacamos o limite que ocorre nessas situações pelo vínculo criado com os profissionais de saúde e pela necessidade de um detalhamento no registro sobre o 
conteúdo conversado na primeira conversa. Se este registro não é feito, é prejudicada a "longitudinalidade" (Starfield, 1994) do atendimento e a qualidade do trabalho de aconselhamento.

Questões “coorporativas" foram relatadas determinando a organização do trabalho. Duas enfermeiras, uma de São Paulo e outra de Fortaleza, relataram que se sentem limitadas, por poderem pedir e comunicar o resultado do teste anti-HIV somente nos casos contidos em protocolos, como pré-natal e tuberculose. No entanto, estas questões podem ser relativizadas quando o critério é pragmático e envolve a mobilização das competências efetivas de cada profissional, por exemplo, estas entrevistadas relataram que, na prática, informavam o resultado do exame negativo, quando percebiam que o paciente estava ansioso e angustiado e sofreria muito para esperar pela consulta com o médico.

Por considerarem que isso não era respaldado pelos seus conselhos profissionais, falavam de maneira receosa. A comunicação do resultado de teste antiHIV pode ser considerada como proporcionadora de conforto e bem-estar, por acalmar um paciente ansioso e angustiado. Por outro lado, pode ser considerada atribuição somente do médico e a comunicação de resultado de teste anti-HIV pode gerar conflitos entre corporações. A prática de comunicar resultados de testes sempre que os resultados são negativos evidenciam os resultados positivos quando os enfermeiros informarem os pacientes que não poderão comunicar o resultado e que estes deverão aguardar pela consulta com o médico, podendo aumentar ainda mais a angústia e a ansiedade. Não foram mencionadas, nessas comunicações, a prática do aconselhamento, com discussões sobre como prevenir uma possível infecção, por exemplo, apenas a informação de que o resultado do teste anti-HIV deu negativo, para alívio do paciente.

Um enfermeiro relatou que poderia realizar o aconselhamento pós-teste, porém, geralmente esta parte ficava reservada aos médicos. Ele realizava o pedido de exames baseados em protocolos, especialmente das gestantes, na primeira consulta, o que era combinado com os médicos.

"Esses resultados eu acho que assim, eles estão procurando mais a equipe médica pra pegar esse resultado. Eles vêm, mas a maioria já tem mostrado, porque, vamos supor, quando eu faço a primeira consulta do pré-natal, no caso das 
gestantes, então a gente faz toda aquela parte burocrática de preencher cartão. A gente tem um acordo com os médicos de solicitar os exames de rotina. Aqueles que a gente não pode solicitar, eles carimbam e solicitam. Então assim, a primeira consulta. A segunda consulta que já é o retorno com esses exames, já vai pro médico, na maioria das vezes apresenta pra equipe médica. Quando eles vêm, vem com o bichinho já sabendo que é negativo. A gente fica mais com o pré-teste, não quer dizer que a gente também não possa, a oportunidade mais é com os médicos das equipes. " (Enfermeiro 2a de Fortaleza)

Curiosamente, a gerente da UBS onde este enfermeiro atuava, considerava que ele seria a pessoa mais indicada a realizar a comunicação de um resultado positivo, mais do que os médicos, inclusive, por sua formação em práticas integrativas e complementares de saúde, como terapia comunitária e massoterapia, o que nunca foi necessário, por, segundo ela, nunca ter havido um caso de comunicação de resultado positivo na unidade. Por esse caso, a autorização para realizar a comunicação do resultado do teste anti-HIV parecia depender da decisão do gestor local.

A Política Nacional de Atenção Básica propõe que o gestor municipal defina os protocolos de pedidos de exames autorizados pelos enfermeiros, observadas as regulamentações de cada conselho profissional:

[Uma atribuição específica do enfermeiro da Estratégia Saúde da Família é] solicitar exames complementares e prescrever medicações, conforme protocolos ou outras normativas técnicas estabelecidas pelo gestor municipal ou do Distrito Federal, observadas as disposições legais da profissão (Brasil, 2006, p. 44)

Por essas "questões corporativas", provavelmente, obtivemos mais relatos de comunicação de teste anti-HIV positivos por parte de médicos. Para profissionais que nunca haviam comunicado o resultado do teste anti-HIV, pedimos para imaginarem como seria esse caso e como reagiriam.

Durante a comunicação de resultado de teste anti-HIV negativo para casos no qual o pedido de rotina é previsto e realizado, como de tuberculose e gestantes, foram mais raras avaliações sobre situações de risco ou conversas sobre uso de preservativo. 
“Eu comunico como se fosse os outros exames. Em geral, quando é gestante, eu não dou assim uma ênfase pro HIV quando ele veio negativo e ele tá fazendo parte de todo um resto que a gente pediu. Eu digo: 'Olha, deu normal, glicemia normal, você não tá com diabetes gestacional, deu negativo pra sífilis, deu negativo pra HIV, deu negativo pra nanana... tal.' Não falo: 'E o HIV...' E nem acho que elas tão preocupadas. Não tenho impressão que elas por terem colhido, ficam pensando: 'Colheu HIV, então vamos ver o que deu o HIV.'”' (Médica de São Paulo)

Já nos casos de pedido de teste anti-HIV ofertados por suspeita de DST, algum suposto "grupo de risco" ou por demanda do usuário, foram relatadas conversas sobre avaliação de riscos e uso de preservativos.

"Tem um menino, crente, e ele tinha tido uma relação sexual sem proteção, atrás da igreja. E ele tinha gonorreia. Então eu tratei, tudo, orientei, conversei. E na outra consulta, conversei com ele, falei sobre os riscos, falei sobre a aids, o porquê não poderia fazer sem camisinha." (Médica de São Paulo)

Destacamos o relato de uma entrevistada que enfatiza em todas as comunicações de resultado, inclusive negativo, a importância do uso do preservativo e limites do teste: "Eu sempre tento frisar a importância da prevenção, que aquele resultado foi negativo e bom que continue assim, que o importante é fazer prevenção, e a forma melhor, a forma de prevenir é através do uso do preservativo." (Médica de Fortaleza) Entretanto, como questão relacionada à organização do trabalho, esta mesma entrevistada reclama de falta de tempo para um atendimento adequado devido à alta demanda.

Na UBS de Fortaleza na qual não há estrutura para que o teste anti-HIV seja realizado na própria UBS e os usuários precisam realizá-lo em laboratório localizado em bairro próximo, comumente os usuários já recebem resultado nesse laboratório, salvo raras exceções. Uma enfermeira relata que eles não costumam ter acesso ao resultado do teste anti-HIV, nem por um sistema de informação da prefeitura, diferentemente de outros exames, sendo necessária a retirada pelo paciente pessoalmente no laboratório.

“Quando dá positivo, eles já mandam, já informam, quando o paciente vai buscar o resultado, eles já fazem todo o trabalho lá no [serviço especializado em DST/aids]. (...) Eles já encaminham pro [hospital que atende pessoas que vivem com 
HIV] também (...). Tem a psicóloga, tem a assistente social pra dar esse segmento aí. (...) Tem [que pegar o resultado do teste anti-HIV no laboratório mesmo nos casos negativos]. (...) Eles não disponibilizam pelo sistema. Aí o paciente mesmo que tem que pegar o resultado." (Enfermeira $2 \mathrm{~b}$ em Fortaleza)

Geralmente, após a comunicação do resultado positivo para HIV, os pacientes são encaminhados para serviços especializados para acompanhamento, e se necessário a realização de tratamento antirretroviral. Os profissionais de saúde mencionam o melhor atendimento para o paciente, por haver profissionais que conhecem melhor seu tratamento e o serviço ser mais estruturado, com mais opções de profissionais de saúde e agilidade no encaminhamento, constatação que condiz com avaliações realizadas em serviços especializados para atendimento de pessoas vivendo com HIV e aids já citadas (Nemes et al., 2004 e Melchior et al., 2006). Esta qualidade diferenciada é associada à construção da resposta brasileira à epidemia de aids, que acompanhou o processo democrático brasileiro e marcada pelas reivindicações dos movimentos sociais, principalmente pelo movimento gay, como também foi descrito na introdução desta dissertação. O padrão tecnológico almejado nos serviços especializados em DST/aids é caracterizado pelo atendimento multiprofissional e busca pelo respeito da individualidade dos usuário e seu direito à cidadania. A equipe Qualiaids avaliou 322 serviços de sete estados brasileiros, incluindo os dois estudados nesta dissertação, São Paulo e Ceará, através de observação do fluxo assistencial e entrevista semiestruturada com o gerente ou supervisor da equipe (Nemes et al., 2004 e Melchior et al., 2006). Segundo esta avaliação, nesses serviços especializados em DST/aids, existe pelo menos um médico infectologista em $74 \%$ dos serviços, com a maioria das equipes contando com pelo menos um médico com mais de cinco anos de experiência, o que é considerado um atributo da qualidade do cuidado médico. Estes serviços contam com pelo menos um enfermeiro em $81 \%$ e há presença de outros profissionais acima de $76 \%$, assistente social, psicólogo e/ou farmacêutico. O aconselhamento pré e pósteste nesses serviços especializados em DST/aids alcança alto índice de realização, 93,5\% para o pré-teste e 96,3\% para o pós-teste. Já outra avaliação já citada, em 37 municípios do Estado de São Paulo (Castanheira et al., 2009), através de questionário estruturado autorrespondido pelos gerentes e/ou equipe técnica das unidades da rede 
básica, indicou que as instalações, em sua maioria, não são adequadas à demanda e $32 \%$ do total das unidades (36/113) relataram ter permanecido sem nenhum médico por algum período durante o último ano.

Os nossos entrevistados relataram abordagens diferenciadas para casos de pacientes com resultado positivo: alguns pacientes deixavam de ser acompanhados pela UBS; alguns retornavam ao serviço de atenção básica somente para pegar o encaminhamento para especialistas, a pedido dos médicos dos serviços especializados; outros continuavam a ser acompanhados pela própria UBS e também são acompanhados pelo serviço especializado. Deixar de ser acompanhado pela UBS pode ser uma escolha do próprio paciente, por preferir ser atendido em um serviço especializado distante de onde mora, para não ser identificado, e não mencionar sua soropositividade para os profissionais da UBS, como é relatado por uma enfermeira.

"Quando se identifica o HIV, o [serviço especializado em DST/aids], que é o serviço especializado, é descentralizado, então as pessoas preferem, às vezes, ser atendidas em outras áreas, porque, como a unidade básica é muito próxima deles, talvez tenha até pacientes que a gente não saiba que tenha, né? Pode acontecer. (Aí vai direto pro [serviço especializado em DST/aids]?). É, ele descobre numa transfusão de sangue, ele vai direto pro [serviço especializado em DST/aids], ele não vai falar com a gente, então por isso que eu não tenho nenhum." (Enfermeira 1a de São Paulo).

Já um médico da mesma UBS relatou que atendia dois casos de pacientes diagnosticados com HIV em suas questões clínicas, uma mulher de 70 anos e um homem de 40. Estes casos não foram diagnosticados por ele e o acompanhamento da infecção pelo HIV era realizado em serviço especializado.

"Eu já atendi paciente aqui que é diagnosticado, mas já acompanhado no [hospital especializado em DST/aids e hepatites virais], que veio aqui porque o [hospital especializado em DST/aids e hepatites virais] pediu pra eu encaminhar pra algum lugar." (Médica 2a de Fortaleza)

No caso da comunicação de resultados positivos, há um sentimento de angústia antecipada pelos profissionais de saúde que impacta a disponibilidade para o oferecimento do teste ainda que poucos entrevistados passaram por esta experiência. 
Para evitar situações difíceis de lidar emocionalmente, os profissionais dizem enfocar os aspectos biomédicos do tratamento e tentar ignorar questões afetivas.

Alguns profissionais trazem como dificuldade a falta de capacidade de entendimento das informações por alguns pacientes que eles imaginam existir, relacionado a pouca escolaridade:

"É porque o que eu acho pior é a ignorância, tá entendendo? É você explicar isso pra uma pessoa que não entende direito uma prescrição de remédio de verme. A pessoa não estudou nada, é analfabeta, você entregar um diagnóstico desse..." (Médica 2 a de Fortaleza)

Nesta fala, a profissional mistura a capacidade intelectual de compreensão e a capacidade emocional de lidar com uma notícia difícil e com consequências para a saúde, o que discrimina pessoas com baixa escolaridade e demonstra uma dificuldade própria em adaptar informações técnicas de diagnóstico e tratamento para pessoas com baixa escolaridade.

Alguns profissionais, ao descreverem seu cotidiano, expressam-se sem emoções e argumentam que esta reação é o costume pelo tempo de experiência.

Geralmente, a comunicação dos exames é realizada pelos médicos. Eles são informados, antes de se encontrarem com o paciente.

"Não é que eu abro o exame e é uma surpresa. HIV a gente é avisado antes." (Médica 2 de São Paulo)

No caso de exame positivo, é dada prioridade e urgência e o trabalho pode ser realizado de maneira multiprofissional.

Alguns relatam que o agente comunitário de saúde não deve saber do resultado positivo do exame anti-HIV, por ser vizinho do usuário e que pode haver discriminação por falta de formação.

"Existe preconceito mesmo, é doença de quem faz o que não presta, por mais que a gente explique, ainda existe isso, onde existe ignorância vai ter sempre isso." (Médica 2a de Fortaleza)

Alguns profissionais demonstraram alívio por nunca terem precisado comunicar o resultado de exame de HIV positivo. Outros profissionais falam que traz angústia, por estarem presentes, junto com o paciente, vivenciando um sofrimento. 
“Eu, se você me perguntar se eu sei lidar com essa situação, provavelmente não. Eu provavelmente não saberia lidar com a reação de desespero que eu acredito que seja a primeira reação de quem recebe uma notícia de uma doença crônica assim que ainda é tão estigmatizada." (Médica 2a de Fortaleza)

Os profissionais entrevistados podiam se sentir aliviados ao encaminharem os pacientes com resultado positivo para serviços especializados em DST/aids.

"Eu já vi, já presenciei, darem a notícia, no [hospital especializado em DST/aids e hepatites virais], a paciente chorar muito, mas..., manteve, eu observei, a gente se manteve com a paciente o tempo todo, ela chorou, tudo, questionou, aí briga com o marido, esculhamba o marido, todo mundo que tinha passado pela frente, a culpa é de todo mundo." (Médica 2a de Fortaleza)

Esta mesma médica contou um caso de um resultado positivo que foi entregue na unidade, para uma paciente em tratamento de tuberculose, e acessado por uma técnica de enfermagem, que "ficou super assustada" (médica 1a, de Fortaleza). Ela considerou que o resultado foi entregue na unidade por engano, porque usualmente nessa unidade, os resultados dos exames de HIV eram entregues no laboratório. Esta médica pediu para a ACS convocar o paciente, sem dizer para quê.

Embora no relato também demonstrasse um certo susto, a maneira como lidou com isso foi dar procedimentos para o encaminhamento da paciente para realização de novo teste e encaminhamento para o serviço especializado, priorizando conhecimentos biomédicos para cuidados sobre o corpo anatomopatológico, sem alusão a aspectos afetivos.

“A gente se preocupa só em iniciar o tratamento, a pessoa ser avaliada, ser acompanhada, a gente ficou no pé dela pra ver se ela vinha, ela veio, fez o exame, procurou o [hospital especializado em DST/aids e hepatites virais], quando ela tava em tratamento, a gente se tranquiliza." (Médica 2a de Fortaleza)

Há o reconhecimento da importância dos agentes comunitários para a aproximação com a comunidade e do território e a preocupação com o sigilo das informações, por também serem moradores de lá, como é descrito nesse caso pela médica: 
"Pediram só pra comparecer ao posto e pronto. Os agentes de saúde tão acostumados a levar recado assim pela metade e eles não questionam também não, sabe?" (Médica 2a de Fortaleza)

Nas "andanças" da pesquisadora nos serviços de saúde durante o período de campo, conversou com agentes comunitários e todos disseram que sabiam dos casos de pessoas que vivem com HIV de suas áreas e participavam de seu cuidado, tanto em Fortaleza, como em São Paulo. Uma dessas agentes, inclusive, contou sobre sua experiência de cuidado em saúde de uma paciente com HIV, o que remete à já mencionada tensão sobre os limites do trabalho do ACS, sendo morador e profissional do serviço.

A confirmação deste resultado positivo foi dado no próprio laboratório:

"Realmente achei que podia ser engano mesmo e com a confirmação do resultado positivo, com o Western-Blot, o outro exame, aí a própria enfermeira lá, responsável por esta parte, chamou, entregou na mão dela e ela que dá a notícia." (Médica 2a de Fortaleza)

A repetição da amostragem em caso de resultado positivo é um procedimento padrão, segundo site do Ministério da Saúde, para que não haja dúvida sobre a sorologia (Brasil, 2011).

A outra médica desta UBS, que estava de férias no momento e é responsável por esta paciente, conta sobre a dificuldade do caso, especialmente porque a paciente não esperava pelo resultado de HIV positivo, porque fazia tempo que não tinha relações sexuais, e nem a médica, porque é mais comum o resultado negativo, demonstrando que não houve um aconselhamento pré-teste no qual fosse informado sobre o possível período de infecção e os riscos existentes.

"Aqui tem um problema que às vezes demora pra sair o resultado [do teste anti-HIV]. Quando a gente recebeu o resultado dela, ela tava no finalzinho do tratamento [de tuberculose] e deu positivo. Só que aí ela disse: 'Não, mas como esse resultado deu positivo', não sei o quê. 'Faz tanto tempo que eu não tenho relação com ninguém.' Aí a gente, eu, na verdade, quem atendeu ela foi a [outra médica]. Eu tava de férias nesse dia que ela veio pra mostrar o resultado e aí a [outra médica]: 'Não, vamos repetir o exame.' Ela repetiu e veio me mostrar, realmente deu positivo, aí ela tá fazendo acompanhamento lá no [hospital geral], no ambulatório também e 
aí falta ela retornar, só pra mostrar. Acho que ela ia fazer exames de carga viral, essas coisas todas. Mas assim, ela disse que, ela parecia bem surpresa, ah, que fazia muito tempo que ela não tinha relação e tudo. Aí eu conversei com ela: 'Não, mas a senhora vai fazer e tudo, agora a senhora no momento tá bem. A senhora vai pro acompanhamento lá.' Ela já tava com a consulta marcada no ambulatório especializado e falta ela só retornar pra dizer como tá. (...) Ela ficou assustada, claro. Ficou bem assustada, mas eu conversei muito com ela. Eu conversei muito com ela, disse que ela ficasse tranquila, que já existe tratamento, que no momento ela tava bem, o que a gente queria era fazer o acompanhamento dela direitinho pra ela continuar assim. Que qualquer coisa que ela sentisse, ela retornasse na unidade de saúde, tá entendendo? (...) A gente vê tantos resultados negativos, que a gente sempre espera que seja negativo, mas eu acho que ela vai ser acompanhada. Ela tá sem sintomas e eu espero que ela fique bem. Eu me senti, você fica um pouco triste pelo paciente, mas ao mesmo tempo otimista que ela continue como ela tá, bem. Que ela se cuide. Ainda bem que foi descoberto. Eu disse pra ela: 'Foi descoberto e a senhora tá sem sintomas. Já terminou o tratamento da tuberculose.' Ficou tudo bem. Ela recebeu alta com cura da tuberculose. Então o que a gente espera é que ela fique bem." (Médica 2b de Fortaleza)

Como esperado e temido por alguns profissionais de saúde, comunicar o resultado positivo para HIV é difícil, por lidar com sentimentos e emoções difíceis, tanto por parte do paciente, como do profissional de saúde, que sente empatia por este. O resultado positivo pode ser uma surpresa, por ser mais comum o resultado negativo e pela paciente não ter um perfil culturalmente associado a "comportamentos de risco", como ser usuária de drogas ou trabalhadora do sexo.

"Ah, ela era uma senhora também de cor parda, de cabelos grisalhos. (...) Talvez, eh, em torno de 55 anos, talvez uns 54, 55. E cabelos curtos. E, assim, é magra. Mas um bom, um pouco mais magra, baixinha. E você vê que ela não tem um nível de instrução muito bom. Ela, se não me engano, disse que é, que ela é viúva ou separada, mas já há alguns anos. E mora só com um neto. Tem uma filha que não tem condições de criar." (Médica 2b de Fortaleza) 
Uma dificuldade destacada por ela na compreensão da paciente das informações foi seu pouco nível de escolaridade. Perguntada se haveria diferença se ela tivesse um maior nível de escolaridade, a médica destacou os seguintes aspectos:

"Talvez ela não tivesse demorado, talvez tivesse feito os exames com mais antecedência. No dia que ela ficou sabendo, que foi confirmado, tentei explicar tudo direitinho pra ela, algumas coisas pra ela entender que existe um tratamento, que ela ia fazer um acompanhamento direitinho. Talvez fosse melhor pra ela entender isso. E pra ela manter um acompanhamento de forma mais regular, porque ela falta em algumas consultas. (...) Acho que talvez o que mais influencia é o cultural. Assim, do nível de instrução e talvez nível econômico. Talvez, porque estão juntos. (...) Porque às vezes ela fala: 'Eu tô sem dinheiro pra fazer o exame.' Ela às vezes atrasava a realização do exame por causa disso." (Médica 2b de Fortaleza)

Apesar da surpresa e desta dificuldade, a profissional afirma que estava preparada para informar a paciente sobre os procedimentos necessários sobre seu tratamento, fornecendo informações necessárias, encaminhando para exames para serviços especializados e dando apoio emocional, transmitindo-lhe calma.

Uma médica de São Paulo cita como exemplo o caso de uma trabalhadora do sexo, que, segundo ela, apesar da própria paciente esperar, de certa maneira, que o resultado desse positivo para HIV, por saber que havia se exposto em situações de risco, no caso de falha do uso do preservativo, quando isso realmente aconteceu, sofreu muito.

"Eu tive a última paciente com HIV o ano passado. HIV, ela também não sabia. Mas ela era, ela é profissional do sexo. Ela falou que tinha esse risco, às vezes rompe camisinha. Ela falou: 'Eu sabia que um dia eu podia pegar.' Quer dizer, ela tava melhor preparada. Mesmo assim, depois ela desabou e é muito difícil. (...) Pra mim é angustiante, falar que não [Riso.]. É muito difícil." (Médica 2 a de São Paulo)

Nesse caso, é trazida a dificuldade da médica em não ter com quem compartilhar e nem capacitações para isso. Ela coloca a importância de haver profissionais de saúde mental no serviço como apoio.

"Quando dá positivo pra mim é muito difícil. Eu fico muito angustiada. Fico cheia de dedos pra comunicar. Fico toda, sabe? Não [perguntada sobre se recebeu 
treinamento sobre comunicação de resultado de teste anti-HIV positivo]. Nenhum. A maneira de você dar a notícia é muito difícil. Por exemplo, tem lugares que eu trabalho que tem equipe de saúde mental que às vezes eu peço ajuda." (Médica 2 a de São Paulo)

Ela pondera que, apesar da dificuldade de se comunicar um resultado positivo para HIV, comparando-se com antigamente, é bem mais fácil, pela possibilidade de tratamento.

“Eu tento, eu converso, eu oriento, falo: 'Você vai tratar, não é mais...' Há vinte anos atrás era difícil. Hoje tem tratamento. A grande maioria das crianças que a mãe trata no pré-natal. Eu explico pra elas: 'Provavelmente vai nascer negativo, é uma chance pequena se você fizer direitinho o tratamento. Você pode...' Hoje você tem argumentos que não deixa a paciente, não é um sinal que ela vai morrer. Ela tem HIV. Mas não é que ela vai morrer. Sabe, você pode morrer de velha, falo pra ela. Hoje é mais fácil de você comunicar. Agora há vinte anos atrás, há quinze anos atrás, há dez anos atrás, era bem mais difícil." (Médica 2 a de São Paulo)

Nas narrativas de situações difíceis de lidar emocionalmente, os profissionais relatavam enfocar apenas os aspectos da "técnica-tecnológica" (Schraiber, 2008) de sua prática, tentando ignorar questões afetivas.

Um exemplo ilustrativo é a fala de uma enfermeira, de um serviço mais estruturado de São Paulo, quando convidada a imaginar como seria dar um resultado positivo para o HIV. Disse que poderia ser angustiante, especialmente comunicar o diagnóstico para pessoas casadas, pois envolveria aspectos emocionais difíceis, como a fidelidade do casal. Parece que para os pacientes identificados com os chamados "grupos de risco" no início da epidemia, ou que fujam das normas sociais de alguma maneira, e se aproximem da marginalidade, é mais fácil para os profissionais de saúde comunicarem um resultado positivo para o HIV.

"Eu acho que dependeria muito do caso, se fosse um caso, por exemplo, de uma pessoa que pegou isso simplesmente de um relacionamento casual, uma coisa assim, seria de um jeito. Eu acho que seria muito mais difícil pra mim se eu tivesse que dar pra uma pessoa casada. E que aí a pessoa traria um monte de questões de fidelidade, de todas as coisas juntas, uma outra carga emocional. Acho que seria bem difícil. Teria que chamar o marido. (...) Teria a questão da fidelidade, da 
culpabilização do outro. Da dinâmica familiar, não é verdade? Acho que seria bem mais complicado, porque teria muitas outras coisas envolvidas. (...) Teria que chamar o marido, pra colher o sangue do marido, apoiar a família, conversar com ele, tentar fazer uma intermediação pra discutir a questão deles, de fidelidade ou preparar a mulher pra isso. Imagino que seja muito mais complicado. (...) Como se reage? Tanto de um lado, como de outro, porque ela também pode ter, ela pode ter tido um relacionamento extraconjugal. E depois? Imagina se ela tiver um relacionamento extraconjugal e ela tem relação com o marido desprotegida, porque é casada. Nossa Senhora! Eu fico pensando, tomara que isso nunca apareça, porque como eu vou lidar com isso? Eu não tenho capacitação pra isso. Ia ter que ser na raça, como várias outras coisas aqui já foram na raça." (Enfermeira 1 a de São Paulo)

Neste caso imaginário, ela lidaria com essa dificuldade, focando-se nos aspectos instrumentais do trabalho, em detrimento dos comunicacionais e afetivos, que se aproximariam da "técnica-arte", que, articulada com a "técnica-tecnológica", compõe as práticas de saúde.

"Eu acho que, eu tentaria sempre partir pela parte técnica, sabe? Partindo pela parte técnica e aí não sei. Tentar ver. Eu não sei, eu não sei. Nós, técnicos, a gente que trabalha na área da saúde, nossa primeira, parte pela parte técnica e depois ver o restante, eu ia partir daí. (Parte técnica seria o quê?) Pedir, encaminhar pro [serviço especializado em DST/aids], explicar, colher nova amostra, sabe? Esse tipo de coisa. (Entendi.) E que tem toda parte também, depois que se dá um resultado positivo desse, a gente encaminha pro SAE e vai pra atenção secundária, e depois volta aqui só pra gente fazer a ponte. (Ah, depois volta?) Volta pra gente poder ir acompanhando. (Ah, então vocês fazem acompanhamento quando o paciente tem HIV?) Sim, sim, pra ver se ele, quer dizer, é que na nossa área não tem, mas imagino que as outras enfermeiras façam isso. A gente não tem muitos casos aqui." (Enfermeira 1 a de São Paulo)

Kiss e Schraiber (2011), ao analisarem os discursos dos profissionais de saúde da atenção básica sobre a violência contra mulheres, elaboram uma reflexão sobre o sofrimento, que dialoga com as questões afetivas presentes neste estudo: 
O sofrimento que ultrapassa a dimensão fisiopatológica não encontra sentido tecnológico assimilável e compatível ao dos objetos biomédicos e dificilmente conseguirá integrar-se na proposta de intervenção. (p. 1950)

Como perspectiva de intervenção para situações mobilizadoras de sofrimento, no caso estudado a violência e que também cabe para nosso estudo, as autoras sugerem a inovação no protocolo de atendimento, de forma que alie elementos técnico-científicos com intersubjetividade, "permitindo o desenvolvimento de um olhar mais sensível e informado quanto a questões médicosociais". (p. 1951)

\subsection{REFLEXÕES DECORRENTES DA SITUAÇÃO DE ENTREVISTA}

Alguns entrevistados disseram ter refletido sobre sua prática a partir da entrevista. Como apresentado em "Condições das entrevistas", apesar do tempo dispendido para conceder a entrevista e do receio de alguns profissionais em serem avaliados, todos, ao final, demonstraram alguma satisfação por terem reconhecida sua experiência profissional como valorosa.

"Eu acho interessante. Bom porque você, é interessante você compartilhar suas experiências profissionais. A gente que trabalha em Saúde Pública. É interessante você contar suas experiências. É uma oportunidade até de estudo, de pesquisa, que você vai levar pro seu trabalho. Isso vai ser divulgado com certeza, aí vai servir pra outras pessoas melhorarem o seu trabalho, o seu local. As políticas públicas todas vêm de pesquisa. A gente trabalha com pesquisa, tem alguns banners aqui." (Enfermeiro 2a de Fortaleza)

Uma das entrevistadas, médica, relatou que gostou da conversa por ter sido uma entrevista individual, disse que não se sente à vontade ao conversar em público. Assim, para um tema delicado como este, foi uma escolha acertada conversar pelo método de entrevistas individuais e não através de métodos em grupo, como grupo focal.

“Eu não sou de falar em público. Eu gosto assim quando é de perto, uma coisa mais fechada sim. Falar pra plateias não. Geralmente quando é uma coisa 
mais fechada eu falo, me relaciono bem (...). Quando você colocou se a gente é preparado pra dar [o diagnóstico], só, a gente não faz curso, não faz nada, é só o tempo que vai... (...) O tempo de experiência vai ajudando, você tenta contornar e hoje você tem uma coisa pra oferecer. (...) Você já fala pra paciente: 'Você tem tratamento, a criança provavelmente vai nascer negativa. Se der positivo, pode acontecer até que um ano de idade pode ser que [negative]...” (Médica 2 de São Paulo)

Outra entrevistada relata a reflexão trazida para si sobre o trabalho e especialmente sobre o tema HIV/aids e para outros profissionais do serviço com a intervenção da pesquisadora. Ela relata a importância dessa pausa para reflexão na correria do cotidiano do trabalho.

"Eu me sinto estranha, fazia tempo que eu não pensava nesse assunto. Acho que só parei pra pensar no HIV/aids, porque você veio me entrevistar. Como eu te falei, não tem feito parte da nossa agenda. E um pouco a gente acaba vivendo em função do que é colocado pra gente, então eu acho que isso é um erro estratégico. Eu não faço parte do plano tático. Então um pouco eu trabalho com as coisas que chegam ali. Quando não chega, eu vou trabalhando com as coisas que chegam e não tem chegado muito essa demanda de a gente qualificar mais essa atenção, fazer melhor, buscar mais gente, melhorar, por exemplo, o atendimento do jovem. Na prefeitura a gente não tem programa de adolescentes. Então um pouco eu me sinto mal de estar deixando um tema que eu sei, parando pra pensar, que é extremamente relevante, ter de deixar de lado, porque eu acabo vivendo o dia-a-dia e não consigo ir além. (...) Pensar sobre o trabalho é bom também. Sempre faz bem. A gente certamente, você vir entrevistar as pessoas aqui vai fazer elas pensarem um pouco mais sobre o assunto e vai trazer um fruto bom. Por isso que uma das coisas que a gente achou legal você vir é isso. A gente, o pesquisador, às vezes ele não deixa uma coisa, ele deixa o tema dele pra gente pensar e isso é legal. Isso é importante." (Gerente 1 de São Paulo)

Uma médica do mesmo serviço dessa gerente relata a importância de uma pesquisa para mobilizar reflexão sobre determinados temas, no caso, o aconselhamento e testagem anti-HIV, para os profissionais do serviço. 
"Acho legal fazer essas reflexões, porque, o que eu queria acrescentar é isso, talvez você vá perceber, pelas suas entrevistas, que a gente tem pouco momento de parar e refletir sobre as nossas práticas. E que isso é muito, muito importante pra que a gente consiga melhorar nossa conduta dentro do serviço. E que por causa de sobrecarga mesmo, muitas famílias pra cada pessoa, o que acontece hoje em dia nas unidades de Estratégias de Saúde da Família é que vira uma 'tocação' geral, que se a gente não tomar cuidado, a gente entra no piloto automático e não para nunca pra refletir pra melhorar, então." (Médica 1a de São Paulo)

Esses relatos demonstram que, mais do que a autorização formal, com a aprovação dos comitês de ética, o material construído depende da relação formada entre os entrevistados e a pesquisadora. Depende do processo de construção desta relação o quanto os participantes contribuem para a realização da pesquisa. 


\section{CONSIDERAÇÕES FINAIS}

A despeito da orientação política de descentralização do aconselhamento e testagem para o HIV dos serviços especializados, no sentido de sua disseminação e oferecimento universal pela rede de serviços de Atenção Primária à Saúde, essa prática encontra obstáculos relacionados a dificuldades estruturais, organização do trabalho e aspectos ético-políticos. Este estudo pode evidenciar a expressão dessas dificuldades, em especial os aspectos ético-políticos, a partir do depoimento dos trabalhadores a respeito dos encontros/conversas em que se realizam ou não os pedidos do teste, ao mesmo tempo em que mostra alguns elementos que podem favorecer o pedido do teste.

A relativa proximidade de serviços especializados em DST/aids nas regiões estudadas facilita o encaminhamento e a recusa em lidar com diálogos difíceis envolvendo temas como sexualidade e relacionamento conjugal nos casos de pedido de testagem anti-HIV por demanda espontânea dos usuários. Além disso, estes serviços são mais bem estruturados, segundo os entrevistados e estudos citados, com profissionais de diversas áreas.

Os profissionais relataram dificuldades estruturais, como pouco tempo para a consulta devido à alta demanda, falta de profissionais e de estrutura física adequada para consultas. Dentro destas limitações, os profissionais relataram que não oferecem o teste anti-HIV de maneira ampla, a não ser nos casos previstos em protocolos, com a justificativa de não estigmatizar usuários, associando-os a comportamentos moralmente reprováveis como infidelidade e promiscuidade.

Destacamos a dificuldade dos profissionais em lidar com a afetividade como obstáculo para realização da prática do acolhimento e, particularmente, do aconselhamento, principalmente o receio e falta de interesse em conversar sobre temas de foro íntimo, como a sexualidade, as relações conjugais, a infidelidade e o sofrimento decorrentes de um resultado positivo para HIV.

Embora a discussão conceitual sobre a epidemia de aids tenha avançado, orientada pelos Direitos Humanos, em direção ao conceito de vulnerabilidade, superando os chamados "grupos de risco", discurso inclusive incorporado pelos 
manuais do Ministério da Saúde contendo normas para a Atenção Básica, observamos na prática dos serviços uma seleção de grupos prioritários para testagem muito semelhante aos primeiros grupos atingidos pela epidemia de aids, perpassada não somente por dados epidemiológicos, mas também pelos valores relacionados a esses grupos. Nesta seleção de grupos para quem oferecer o teste anti-HIV, os profissionais acabam exercendo discriminação e aumentando o estigma sobre alguns grupos, como jovens, homossexuais e trabalhadoras do sexo, mesclando informações técnicas e valores sociais.

Como fator promotor da testagem anti-HIV, destacamos o papel da mídia e das propagandas governamentais.

Destacamos ainda algumas inovações trazidas pelos profissionais para divulgar a testagem de HIV e fazer emergir sua demanda pelos usuários, ampliando assim o diagnóstico, conforme é preconizado atualmente pelo Ministério da Saúde (2003). Conversas sobre sexualidade em grupos não abrangidos pelos pedidos contidos nos protocolos do pré-natal e tuberculose, possibilitaram reflexão nos usuários sobre sua situação de risco e a procura por um profissional de sua confiança para demandar o teste anti-HIV. Quando questões sobre a sexualidade dos usuários fazem parte de protocolos do serviço de saúde, incluindo o uso de preservativo, os profissionais de saúde consideram a abordagem tranquila e não invasiva.

Observamos, no entanto, que não basta inserir um protocolo padronizado para testagem anti-HIV de maneira geral para haver a prática do aconselhamento nos serviços, pois, nos casos baseados em protocolo relacionados ao pré-natal e à tuberculose, foram relatados menor diálogo durante a comunicação de resultado, comparando-se com outros casos.

A afetividade, comumente, é considerada fora do escopo das intervenções profissionais de médicos e enfermeiros, sendo um aspecto segmentado e destinados aos profissionais da área de "saúde mental". Sugerimos que, para aprimorar a prática do acolhimento e do aconselhamento, os serviços sejam reorganizados, de forma que se incorpore a afetividade na formação dos profissionais, como parte da "arte" presente na "técnica", integrado com seu aspecto "tecnológico", para efetivar a integralidade do cuidado. 
Destacamos dos relatos a falta de espaços nos serviços de supervisão e formação continuada para discussão sobre a prática cotidiana, informações técnicas, valores presentes na sociedade, como o estigma e a discriminação que acompanham a epidemia de aids.

Por fim, sugerimos que espaços contínuos para discussão de casos contribuiriam para apoiar os profissionais quando tiverem de lidar com dilemas éticos e morais, motivos de grande mobilização afetiva. Desta maneira, os profissionais poderiam se sentir apoiados para realizar a prática de acolhimento e, particularmente, de aconselhamento. 


\section{REFERÊNCIAS BIBLIOGRÁFICAS}

Araújo MAL, Farias FLR, Rodrigues AVB. Aconselhamento pós-teste anti-HIV: análise à luz de uma teoria humanística de enfermagem. Esc. Anna Nery Rev. Enferm;10(3):425-431, dez. 2006.

Araújo MAL, Vieira NFC, Silva RM. Implementação do diagnóstico da infecção pelo HIV para gestantes em Unidade Básica de Saúde da Família em Fortaleza, Ceará. Ciência \& Saúde Coletiva, 13(6):1899-1906, 2008

Ayres JRCM, França Junior I, Calazans GJ, Saletti Filho HC. O conceito de vulnerabilidade e as práticas de saúde: novas perspectivas e desafios. In: Czeresnia D, Freitas CM. de. (orgs.). Promoção da saúde: conceitos, reflexões, tendência. Rio de Janeiro: Fiocruz; 2003.

Barreto M. Violência, saúde e trabalho: uma jornada de humilhações. São Paulo: EDUC; 2006.

Bellenzani R. Sexualidade entre jovens das comunidades anfitriãs de turismo: desafios para a prevenção das DST/HIV e o Programa Saúde da Família. 2008. Dissertação (Mestrado em Psicologia Social e do Trabalho) - Instituto de Psicologia, Universidade de São Paulo, São Paulo.

Berquó, E.; Barbosa, R.M.; Lima, L.P.; Grupo de Estudos em População, Sexualidade e Aids. Uso do preservativo: tendências entre 1998 e 2005 na população brasileira. Rev. Saúde Pública [online]. 2008, vol.42, suppl.1, pp. 34-44.

Brasil. Ministério da Saúde. Coordenação Nacional de DST e Aids. Aconselhamento em DST, HIV e Aids: diretrizes e procedimentos básicos. 2ª ed. Brasília; 1998. 
Brasil. Ministério da Saúde. Secretaria de Secretaria de Políticas de Saúde. Coordenação Nacional de DST e Aids. Aconselhamento: um desafio para prática integral em saúde - avaliação das ações. Brasília, DF; 1999.

Brasil. Ministério da Saúde. Secretaria de Vigilância em Saúde. Programa Nacional de DST e Aids. Aconselhamento em DST/HIV/Aids para a Atenção Básica. Brasília, DF; 2004a.

Brasil. Ministério da Saúde. Secretaria de Vigilância em Saúde. Programa Nacional de DST e Aids. Implicações Éticas do Diagnóstico e da Triagem Sorológica do HIV. Brasília, DF; 2004b. Série Legislação n. ${ }^{\circ} 2$.

Brasil. Ministério da Saúde. Secretaria de Vigilância em Saúde. Programa Nacional de DST e Aids. Oficina de aconselhamento em DST/HIV/Aids para a Atenção Básica. Brasília, DF; 2005a.

Brasil. Ministério da Saúde. Secretaria de Atenção à Saúde. Departamento de Ações Programáticas Estratégicas. Área Técnica de Saúde da Mulher. Pré-natal $e$ Puerpério: atenção qualificada e humanizada - manual técnico. Brasília, DF; 2005b.

Brasil. Ministério da Saúde. Secretaria de Atenção à Saúde. Departamento de Atenção Básica. Política nacional de atenção básica. Brasília, DF; 2006.

Brasil. Ministério da Saúde. Secretaria de Vigilância em Saúde. Departamento de DST/Aids e Hepatites Virais. Boletim epidemiológico Aids e DST. Ano VII - $\mathrm{n}^{\circ} 1$ $27^{\mathrm{a}}$ a $52^{\mathrm{a}}$ - semanas epidemiológicas - julho a dezembro de 2009 . Ano VII - $\mathrm{n}^{\mathrm{o}} 1-01^{\mathrm{a}}$ a $26^{\mathrm{a}}$ - semanas epidemiológicas - janeiro a junho de 2010. Brasília, DF; 2010a.

Brasil. Ministério da Saúde. Secretaria de Vigilância em Saúde. Departamento de DST/Aids e Hepatites Virais. Dados de aids no Brasil: dezembro 2010 [folder]. Brasília, DF; $2010 b$. 
Brasil. Ministério da Saúde. Departamento de DST, Aids e Hepatites Virais. Tipos de exames. [homepage na internet]. [Acesso em 24 nov 2011]. Disponível em: http://www.aids.gov.br/pagina/tipos-de-exames

Brito AM; Castilho EA; Szwarcwald CL. AIDS e infecção pelo HIV no Brasil: uma epidemia multifacetada. Revista da Sociedade Brasileira de Medicina Tropical, v.34, n.2, p.207-217, mar-abr, 2000.

Castanheira ERL, Dalben I, Almeida MAS, Puttini RF, Patrício KP, Machado DF, Caldas Jr ALC, Nemes MIB. Avaliação da Qualidade da Atenção Básica em 37 Municípios do Centro-Oeste Paulista: características da organização da assistência. Saúde e Sociedade, v.18, supl.2, 2009.

Cintra FA, Sawaia BB. A significação do glaucoma e a mediacão dos significados de velhice na perspectiva Vygotskiana: subsídios para a educação à saúde. Rev.Esc.Enf.USP, v.34, n.4, p. 339-46, dez. 2000.

COREN-SP. Conselho Regional de Enfermagem de São Paulo. Principais Legislações para o Exercício da Enfermagem; 2011.

D' Oliveira AFPL, Schraiber LB. Violência de Gênero, Saúde Reprodutiva e Serviços. In: GIFFIN, K.; COSTA, S. H. Questões da saúde reprodutiva. Rio de Janeiro: Fiocruz; 1999. cap. 15. p. 281-296

D' Oliveira AFPL, Schraiber LB, Hanada H, Durand J. Atenção integral à saúde de mulheres em situação de violência de gênero - uma alternativa para a atenção primária em saúde. Ciência \& Saúde Coletiva, v.14, n.4, p.1037-1050, 2009.

Delor F, Hubert M. Revisiting the concept of 'vulnerability'. Social Science and Medicine. V. 50, n.11, p. 1557-1570, June 2000. 
Fernandes CRD, Britto IAGS. Atuação médica frente ao paciente portador de HIV no contexto ambulatorial. Rev. bras. ter. comport. cogn; 7(2):205-218, jul.-dez. 2005.

Ferraz DAS. Avaliação da implantação de ações de prevenção das DST/Aids numa Unidade de Saúde da Família. 2008. Dissertação (Mestrado em Medicina) Faculdade de Medicina, Universidade de São Paulo, São Paulo.

Ferraz DAS, Nemes MIB. Avaliação da implantação de atividades de prevenção das DST/AIDS na atenção básica: um estudo de caso na Região Metropolitana de São Paulo, Brasil. Cad. Saúde Pública, Rio de Janeiro, 25 Sup 2:S240-S250, 2009

Ferreira VSC, Andrade CS, Franco TB, Merhy EE. Processo de trabalho do agente comunitário de saúde e a reestruturação produtiva. Cad. Saúde Pública, 25(4):898906. 2009.

Figueiredo R. Uso de preservativos, risco e ocorrência de gravidez não planejada e conhecimento e acesso à contracepção de emergência entre mulheres com HIV/aids. Ciência \& Saúde Coletiva, 15(Supl. 1):1175-1183, 2010.

Filgueiras SL, Deslandes SF. Avaliação das ações de aconselhamento. Análise de uma perspectiva de prevenção centrada na pessoa. Cad. Saúde Pública, Rio de Janeiro, 15(Sup. 2):121-131, 1999.

França MSJ. Política, direitos humanos e Aids: uma conversa com Paulo Roberto Teixeira. Interface, vol. 12 no.27 Botucatu Oct./Dec. 2008

França Junior I, Calazans G, Zucchi EM, Grupo de Estudos em População, Sexualidade e Aids. Mudanças no âmbito da testagem anti-HIV no Brasil entre 1998 e 2005. Rev. Saúde Pública [online]. 2008, vol.42, suppl.1, pp. 84-97 
França Junior I, Ayres JRCM. Saúde pública e direitos humanos. In: Fortes PAC, Zoboli ELCP. Bioética e saúde pública. São Paulo: Centro Universitário São Camilo e Edições Loyola; 2003. Cap. 5, p. 63-69.

Galvão J. 1980-2001: uma cronologia da epidemia de HIV/AIDS no Brasil e no mundo. Rio de Janeiro: ABIA; 2002.

Goffmann E. Estigma: notas sobre a manipulação da identidade deteriorada. $4^{\text {a }}$ ed. Rio de Janeiro: LTC, 2008.

Jordan M, Lopes JF, Okazaki E, Komatsu CL, Nemes MIB. Aderência ao tratamento anti-retroviral em AIDS: revisão da literatura médica. In: Teixeira PR, Paiva V, Shimma E. Tá difícil de engolir? Experiências de adesão ao tratamento antiretroviral em São Paulo. São Paulo: Nepaids; 2000. Cap. 1, p. 5-26.

Kiss LB, Schraiber LB. Temas médico-sociais e a intervenção em saúde: a violência contra mulheres no discurso dos profissionais. Ciência e Saúde Coletiva, 16 (3): 1943-1952, 2011.

Landroni MAS. Aids e gravidez: desafios para o cuidado nos serviços de saúde de São Paulo. 2004. Dissertação (Mestrado em Saúde Pública) - Faculdade de Saúde Pública, Universidade de São Paulo, São Paulo.

Lima R. Voz da rua. In: Rede HumanizaSUS. Blog de raylimalima. Ainda há tempo. 2010. [homepage na internet]. [Acesso em 14 fev 2012]. Disponível em http://www.redehumanizasus.net/10012-ainda-ha-tempo

Melchior R, Nemes MIB, Basso CR, Castanheira ERL, Alves MTSB, Buchalla CM, Donini AA e Equipe QualiAids. Avaliação da estrutura organizacional da assistência ambulatorial em HIV/Aids no Brasil. Rev. Saúde Pública 2006; 40(1): 143-51. 
Mencarelli VL, Vaisberg TMJA. Contratransferência e compaixão: encontro clínico com um rapaz HIV+. Psic. Clin., Rio de Janeiro, vol.19, n.1, p.93 - 107, 2007

Minayo MCS. $O$ desafio do conhecimento: pesquisa qualitativa em saúde. $11^{\text {a }}$ edição. São Paulo: Hucitec; 2008.

Moreno DMSC, Reis AOA. O momento da comunicação do resultado sorológico para o HIV sob a ótica winnicottiana. Pulsional Revista de Psicanálise, ano XV, $\mathrm{n}$. $156,20-25 ; 2002$.

Moreno DMSC. A saúde pública e a psicanálise: a produção do conhecimento no Brasil acerca da AIDS. 2006. Dissertação (Mestrado em Saúde Pública) - Faculdade de Saúde Pública, Universidade de São Paulo, São Paulo.

Nemes MIB, Castanheira ERL, Melchior R, Alves MTSSB, Basso CR. Avaliação da qualidade da assistência no programa de AIDS: questões para a investigação em serviços de saúde no Brasil. Cad. Saúde Pública, Rio de Janeiro, 20 Sup 2:S310S321, 2004

Obermeyer CM, Osborn OM. The Utilization of Testing and Counseling for HIV: A Review of the Social and Behavioral Evidence. Am J Public Health. 2007; 97:17621774

Obi SN, Ifebunandu NA. Consequences of HIV testing without consent. International Journal of STD \& AIDS. 2006; 17: 93-96.

Paiva V. O simbolismo da AIDS, alteridade e cidadania. In: Em tempos de AIDS: viva a vida: sexo seguro, prevenção, drogas, adolescentes, mulheres, apoio psicológico aos portadores. São Paulo: Summus; 1992. 
Paiva V. Fazendo Arte com a Camisinha: Sexualidades Jovens em Tempos de Aids. São Paulo: Summus; 2000.

Paiva V. Sem mágicas soluções: a prevenção e o cuidado em HIV/ AIDS e o processo de emancipação psicossocial. Interface - Comunic, Saúde, Educ, v.6, n.11, p.25-38, 2002.

Paiva V, Venturi G, França-Jr I, Lopes F. Uso de preservativos: pesquisa nacional MS/IBOPE, Brasil; 2003.

Paiva V, Pupo LR, Barboza R. O direito à prevenção e os desafios da redução da vulnerabilidade ao HIV no Brasil. Rev Saúde Pública 2006;40(Supl):109-119.

Parker R. A construção da solidariedade: AIDS, sexualidade e política. Rio de Janeiro: Relume-Dumará; 1994.

Parker R. Construindo os alicerces para a resposta ao HIV/AIDS no Brasil: o desenvolvimento de políticas sobre o HIV/AIDS, 1982-1996. Divulgação em Saúde para Debate, Rio de Janeiro, n. 27, p. 8 - 49, agosto 2003.

Pinheiro TF, Couto MT, Silva GSN. Questões de sexualidade masculina na atenção primária à saúde: gênero e medicalização. Interface - Comunic., Saude, Educ., v.15, n.38, p.845-58, jul./set. 2011.

Prefeitura de Fortaleza [homepage na internet]. [Acesso em 22 fev 2011]. Disponível em: http://www.sms.fortaleza.ce.gov.br/sms_v2/redes_atencaoBasica_PSF.asp

Prefeitura de São Paulo. [homepage na internet]. [Acesso em 22 fev 2011]. Disponível em http://www.prefeitura.sp.gov.br/cidade/secretarias/saude 
Primary care doctors fail to offer tests, survey says: medical students need additional training. Special Coverage of 41st IDSA Conference. AIDS Alert. 2003 Dec;18(12):157-8.

Pupo LR. Aconselhamento em DST/aids: uma análise crítica de sua origem histórica e conceitual e de sua fundamentação teórica. 2007. Dissertação (Mestrado em Medicina) - Faculdade de Medicina, Universidade de São Paulo, São Paulo.

Raxach JC et al. (orgs). Prevenção posithiva: estado da arte. Rio de Janeiro : ABIA; 2009. -(Coleção ABIA. Políticas públicas; 8)

Ribeiro RC. A construção de um município saudável: descentralização e intersetorialidade - experiência de Fortaleza. Saúde e Sociedade. V. 6 No2 ago$\operatorname{dez} / 1997$.

Santos CRC. A politização da dor e da indignação de pessoas que vivem ou convivem com o HIV/aids: a participação política em uma ONG como forma de fortalecimento psicossocial. São Paulo. 2004. Tese (Doutorado em Psicologia Social e do Trabalho) - Instituto de Psicologia, Universidade de São Paulo, São Paulo.

Santos NJS, Buchalla CM, Fillipe EV, Bugamelli L, Garcia S, Paiva V. Mulheres HIV positivas, reprodução e sexualidade. Rev Saúde Pública 2002;36(4 Supl):12-23.

Sawaia BB. Fome de felicidade e liberdade. In: Centro de Estudos e Pesquisas em Educação, Cultura e Ação Comunitária - CENPEC. Muitos lugares para aprender. São Paulo: CENPEC/ Fundação Itaú Social/ Unicef; 2003

Sawaia BB. O Sofrimento ético-político como categoria de análise da dialética exclusão/ inclusão. In: As artimanhas da exclusão: análise psicossocial e ética da desigualdade social; 2006 
Sawaia BB. Psicologia e desigualdade social: uma reflexão sobre liberdade e transformação social. Psicologia \& Sociedade; 21 (3): 364-372, 2009

Schraiber LB. Pesquisa qualitativa em saúde: reflexões metodológicas do relato oral e produção de narrativa em estudo sobre a profissão médica. Rev. Saúde Pública, 29 (1): 63-74, 1995

Schraiber LB, Mendes-Gonçalves RB. Necessidades de saúde e atenção primária. In: Schraiber LB, Nemes MIB, Mendes-Gonçalves RB (orgs.). Saúde do adulto: programas e ações na unidade básica. São Paulo. Hucitec; 1996. Cap. 1.

Schraiber LB. No encontro da técnica com a Ética: o exercício de julgar e decidir no cotidiano do trabalho em Medicina. Interface - Comunicação, Saúde, Educação, v.1, n.1, 1997.

Schraiber LB. O médico e suas interações: a crise dos vínculos de confiança. São Paulo: Hucitec. 2008.

Silva NEK, Ayres JRCM. Estratégias para comunicação de diagnóstico de HIV a parceiros sexuais e práticas de saúde. Cad. Saúde Pública. Rio de Janeiro, 25 (8): 1797-1806, ago, 2009.

Silvestre AJ, Gehl MB, Encandela J, Schelzel G. A Participant Observation Study Using Actors at 30 Publicly Funded HIV Counseling and Testing Sites in Pennsylvania. American Journal of Public Health. Vol. 90, No. 7: 1096-1099, July 2000.

Silva JA, Dalmaso ASW. Agente Comunitário de Saúde: o ser, o saber, o fazer. Rio de Janeiro: Fiocruz. 2002. 
Starfield B. Is primary care essential? The Lancet. Volume 344 (8930). 22 Outubro 1994. P. 1129-1133.

Szwarcwald CL, Souza Junior PRB. Estimativa da prevalência de HIV na população brasileira de 15 a 49 anos, 2004. 2006. In: BRASIL. Ministério da Saúde. Secretaria de Vigilância em Saúde. Programa Nacional de DST e Aids. Boletim Epidemiológico AIDS e DST - ano III - nº 1. Brasília, DF, 2006.

Tarantola D, Gruskin S. New guidance on recommended HIV testing and counselling. The Lancet, v.370, July 21, p.202-203, 2007.

Teixeira PR. Políticas públicas em AIDS. In: Parker R (org.). Políticas, instituições e AIDS: enfrentando a epidemia no Brasil. Rio de Janeiro: Jorge Zahar. ABIA; 1997. Cap. 2.

Teixeira RR. Estudo sobre a técnica e a saúde. Tese (doutorado) - Faculdade de Medicina, Universidade de São Paulo, São Paulo; 2003a.

Teixeira RR. Acolhimento num serviço de saúde entendido como uma rede de conversações. In: Pinheiro R, Mattos RA (Orgs.) Construção da Integralidade: cotidiano, saberes e práticas em saúde. Rio de Janeiro: IMS-UERJ/ABRASCO; 2003b. [homepage na internet]. [Acesso em 15 mar 2008]. Disponível em: http://www.corposem.org/rizoma

Teixeira RR. Humanização e Atenção Primária à Saúde. Ciência \& Saúde Coletiva, 10 (3): 585-597, 2005

Tunala L, Paiva V, Ventura-Filipe E, Santos TLL, Santos N, Hearst N. Lidando com fatores psicossociais que dificultam a adesão das mulheres portadoras do HIV aos cuidados de saúde. In: Teixeira PR, Paiva V, Shimma E. Tá difícil de engolir? 
Experiências de adesão ao tratamento anti-retroviral em São Paulo. São Paulo: Nepaids; 2000. Cap. 3, p. 79-114. 


\section{ANEXO I - ROTEIRO DE ENTREVISTA COM GERENTES}

1) Formação:

2) Sexo:

3) cor/raça:

4) Religião:

5) Idade:

6) Onde nasceu:

7) Há quanto trabalha nesse serviço?

1. Quais são suas atividades aqui? Como são feitas?

2. Como é trabalhar aqui?

3. Qual é o número da população atendida neste serviço?

4. Quais são as principais necessidades de saúde da população que você identifica?

5. Há alguma ação neste serviço que se relacione à aids? Qual?

6. Já houve algum debate sobre a aids neste serviço? Como foi?

7. Como é realizado o pedido de exame de HIV nesta unidade? É realizada comunicação? Como?

Discurso livre. Investigar:

- Por quem? Aonde? Esses dados condizem com os dados encontrados: são os atendimentos realizados pela equipe de enfermagem e pelos médicos?

- O pedido e a comunicação é realizado pelo mesmo profissional? Por qual motivo?

- Há relações interdisciplinares neste momento? 
- E intersetoriais? Há relações com o Serviço de Atendimento Especializado em DST/aids da região? Como são?

8. Quais são as condições facilitadoras para o pedido e a comunicação de resultado? E dificultadoras? Você acha que os profissionais daqui estão preparados pra lidar com isso? Por quê?

9. O pedido e a comunicação de resultado são temas trabalhados nesse serviço? Como?

10. Há alguma diferenciação no planejamento dos atendimentos por alguma condição? Conte um exemplo. [Explorar diferenças entre ser mulher, gestante, de acordo com a idade, raçaletnia]

11. Gostaria de acrescentar algo à entrevista?

12. Como se sentiu ao ser entrevistado? 


\section{ANEXO II - ROTEIRO PARA ENTREVISTAS COM PROFISSIONAIS DE SAÚDE}
1) Função profissional:
2) Sexo:
3) cor/raça:
4) Religião:
5) Idade:
6) Onde nasceu:
7) Há quanto trabalha nesse serviço?

1. Quais são suas atividades aqui? Como são feitas?

2. Como é trabalhar aqui?

3. Quais são as principais necessidades de saúde da população que você identifica?

4. Há alguma ação neste serviço que se relacione à aids? Qual?

5. Você realiza alguma ação relacionada à aids? Qual?

6. Já houve algum debate sobre a aids neste serviço? Como foi?

7. Você se sente preparado para realizar ações de prevenção e assistência relacionadas à aids? Você recebeu algum treinamento para isso?

8. Você costuma pedir o exame de HIV? Você pode me contar algum caso? [Deixar discurso livre. Explorar detalhes:

- Como o usuário era?

- Como ocorreu o pedido? 
- Como a pessoa agia?

- Como você se sentiu?

- Houve comunicação de resultado? Caso sim, como foi? Foi você mesmo ou outro profissional? Explorar relações interdisciplinares e intersetoriais.

9. Você pode me contar algum caso diferente desse?

[Explorar da mesma maneira.

- Mudar a cor, o sexo, a idade e a condição social.]

10. Como você se sente ao pedir o exame de HIV?

[Explorar: sempre você se sentiu assim ou em outro momento foi diferente]

11. O que você acha que facilita pedir o exame de HIV? E o que dificulta? [Caso não tenha sido mencionado: Há trocas em espaços formais e informais? Já teve alguma vez em que para pedir esse exame, você precisou conversar com outro profissional deste serviço? E de outros serviços? Você já precisou encaminhar o paciente para outros serviços? Como foi?]

12. Você costuma comunicar o resultado de exame de HIV? Como são essas comunicações? Elas são realizadas para os mesmos pacientes para quem você realiza o pedido? Você pode me contar um caso?

[Pedir para mudar a cor, o sexo, a idade e a condição social. Explorar detalhes e como se sentiram, paciente e profissional. Buscar relações interdisciplinares e intersetoriais.]

13. Você poderia me contar um caso diferente desse? Quais são as diferenças? Quais são as diferenças entre dar um resultado positivo e um negativo? 
14. Há algum caso que vocês acompanham de um paciente que tenha HIV? Como é realizado esse acompanhamento?

15. Você quer acrescentar ou comentar algo à entrevista? Como foi participar dela? 


\title{
ANEXO III - TERMO DE CONSENTIMENTO LIVRE E ESCLARECIDO PARA GESTOR RESPONSÁVEL PELO SERVIÇO
}

\author{
HOSPITAL DAS CLIINICAS DA FACULDADE DE MEDICINA DA UNIVERSIDADE DE \\ SÃO PAULO-HCFMUSP
}

\section{TERMO DE CONSENTIMENTO LIVRE E ESCLARECIDO}

\section{Gestor Responsável pelo Serviço}

Título da pesquisa (Protocolo de mestrado): Aconselhamento pré e pós-teste anti-HIV na Atenção Básica: a perspectiva dos profissionais de saúde

\section{Pesquisadora: Denise Zakabi}

Esta pesquisa tem como objetivo estudar como se realizam o pedido e a comunicação de resultado de testagem de HIV em serviços de atenção básica à saúde das capitais São Paulo e Fortaleza.

Convidamos você e seu serviço de saúde a participar da pesquisa através de entrevistas com você e outros profissionais de saúde. As entrevistas serão gravadas e transcritas, com a permissão dos entrevistados. O tempo de cada entrevista pode variar entre 30 minutos e 1 hora, dependendo do quanto você e outros entrevistados falarem.

Os riscos da participação são praticamente nulos, embora possa haver algum desconforto em refletir ou falar sobre alguma experiência relacionada ao trabalho. Caso haja qualquer desconforto, você e qualquer entrevistado pode se recusar a responder qualquer pergunta e interromper a entrevista.

Não haverá benefícios imediatos com a pesquisa, mas espera-se que seus resultados possam trazer subsídios para a melhoria do serviço e das políticas locais para a atenção básica à saúde.

1. Você terá acesso, a qualquer tempo, às informações sobre procedimentos, riscos e benefícios relacionados à pesquisa, inclusive para dirimir eventuais dúvidas.

2. Você tem total liberdade de retirar seu consentimento a qualquer momento e suspender sua participação, sem que isto traga qualquer prejuízo à sua atividade profissional ou relações institucionais.

3. Nada do que for dito será comentado com outras pessoas que não sejam os pesquisadores do projeto. Será mantido absoluto sigilo acerca da identidade dos participantes e das pessoas mencionadas durante as entrevistas. Somente os pesquisadores terão acesso às gravações e transcrições na íntegra. 
Em caso de qualquer dúvida sobre a pesquisa, pode-se entrar em contato com a pesquisadora através dos celulares: (11) 9379-5196, (85) 8525-9217 e e-mail: denise-z@ usp.br. Você também pode entrar em contato com sua orientadora, Profa. Dra. Ana Flavia Pires Lucas d' Oliveira, na instituição sede da pesquisa, av. Dr. Arnaldo 455. 2o andar. Telefone: 01130617077. em Pesquisa:

Quanto a dúvidas sobre a ética em pesquisa, o contato pode ser feito para os Comitês de Ética

- CEP do Hospital das Clínicas da Faculdade de Medicina da Universidade de São Paulo Rua Ovídio Pires de Campos, 225 - 5 andar - tel: 3069-6442 ramais 16, 17, 18 ou 20, FAX: 3069-6442 ramal 26 - E-mail: cappesq@ hcnet.usp.br

- CEP/ SMS da Secretaria Municipal de Saúde, Rua General Jardim, 36 - $8^{\circ}$ andar, Fone: $3397-$ 2464 / Fax: 3397-2465, E-mail: smscep@ gmail.com

Declaro que, após convenientemente esclarecido pela pesquisadora e ter entendido o que me foi explicado, consinto em lhe conceder uma entrevista e que ela realize a observação deste serviço para a pesquisa "Aconselhamento pré e pós-teste anti-HIV na Atenção Básica: a perspectiva dos profissionais de saúde".

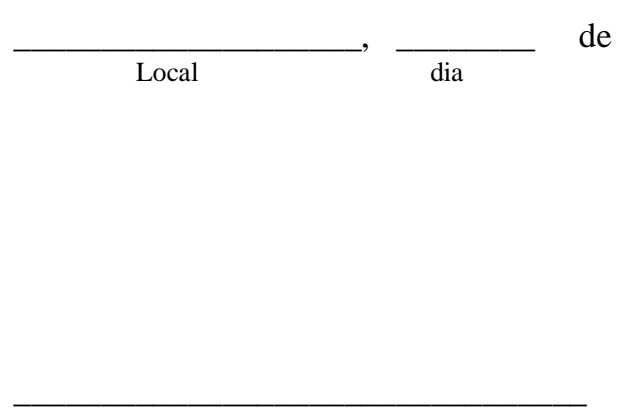

Nome do participante de

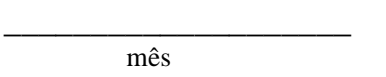

de

ano

Assinatura da pesquisadora

Assinatura do participante 


\title{
ANEXO IV - TERMO DE CONSENTIMENTO LIVRE E ESCLARECIDO PARA PROFISSIONAL DO SERVIÇO
}

\author{
HOSPITAL DAS CLÍNICAS DA FACULDADE DE MEDICINA DA UNIVERSIDADE DE \\ SÃO PAULO-HCFMUSP
}

\section{TERMO DE CONSENTIMENTO LIVRE E ESCLARECIDO}

\author{
Profissional do Serviço
}

Título da pesquisa (Protocolo de mestrado): Aconselhamento pré e pós-teste anti-HIV na Atenção Básica: a perspectiva dos profissionais de saúde

Pesquisadora: Denise Zakabi

Esta pesquisa tem como objetivo estudar como se realizam o pedido e a comunicação de resultado de testagem de HIV em dois serviços de atenção básica à saúde das capitais São Paulo e Fortaleza.

Convidamos você a conceder uma entrevista para pesquisa. As entrevistas serão gravadas e transcritas, com a sua permissão. O tempo de cada entrevista pode variar entre 30 minutos e 1 hora, dependendo do quanto você falar.

Os riscos da participação são praticamente nulos, embora possa haver algum desconforto em refletir ou falar sobre alguma experiência relacionada ao trabalho. Caso haja qualquer desconforto, você pode se recusar a responder qualquer pergunta e interromper a entrevista.

Não haverá benefícios imediatos com a pesquisa, mas espera-se que seus resultados possam trazer subsídios para a melhoria do serviço e das políticas locais para a atenção básica à saúde.

1. Você terá acesso, a qualquer tempo, às informações sobre procedimentos, riscos e benefícios relacionados à pesquisa, inclusive para dirimir eventuais dúvidas.

2. Você tem total liberdade de retirar seu consentimento a qualquer momento e suspender sua participação, sem que isto traga qualquer prejuízo à sua atividade profissional ou relações institucionais.

3. Nada do que for dito será comentado com outras pessoas que não sejam os pesquisadores do projeto. Será mantido absoluto sigilo acerca da identidade dos participantes e das pessoas mencionadas. Somente os pesquisadores terão acesso às gravações e transcrições na íntegra. 
Em caso de qualquer dúvida sobre a pesquisa, pode-se entrar em contato com a pesquisadora através do tel: (11) 9379-5196, (85) 8525-9217 e e-mail: denise-z@ usp.br. Você também pode entrar em contato com sua orientadora, Profa. Dra. Ana Flavia Pires Lucas d' Oliveira, na instituição sede da pesquisa, av. Dr. Arnaldo 455. 2o andar. Telefone: 01130617077. em Pesquisa:

Quanto a dúvidas sobre a ética em pesquisa, o contato pode ser feito para os Comitês de Ética

- CEP do Hospital das Clínicas da Faculdade de Medicina da Universidade de São Paulo Rua Ovídio Pires de Campos, 225 - $5^{\circ}$ andar - tel: 3069-6442 ramais 16, 17, 18 ou 20, FAX: 3069-6442 ramal 26 - E-mail: cappesq@ hcnet.usp.br

- CEP/ SMS da Secretaria Municipal de Saúde, Rua General Jardim, 36 - $8^{\circ}$ andar, Fone: $3397-$ 2464 / Fax: 3397-2465, E-mail: smscep@gmail.com

Declaro que, após convenientemente esclarecido pela pesquisadora e ter entendido o que me foi explicado, consinto em participar da pesquisa "Aconselhamento pré e pós-teste anti-HIV na Atenção Básica: a perspectiva dos profissionais de saúde".

de

dia
Local

mês de

ano 


\title{
ANEXO V - APROVAÇÃO PELO COMITÊ DE ÉTICA EM PESQUISA DA FACULDADE DE MEDICINA DA UNIVERSIDADE DE SÃO PAULO, PROTOCOLO No 258/10
}

\author{
तथा \\ MEDICINA \\ COMITÊ DE ÉTICA EM PESQUISA
}

O Comitê de Ética em Pesquisa da Faculdade de Medicina da Universidade de São Paulo, em sessão de 15.09.10, APROVOU o Protocolo de Pesquisa $n^{\circ} \mathbf{2 5 8 / 1 0}$ intitulado: "Aconselhamento pré e pósteste anti-HIV na Atenção Básica: a perspectiva dos profissionais de saúde" e seus anexos, apresentado pelo Departamento de Medicina Preventiva

Cabe ao pesquisador elaborar e apresentar ao CEP-FMUSP, os relatórios parciais e final sobre a pesquisa .

Pesquisador (a) Responsável: Ana Flávia Pires Lucas D’Oliveira

Pesquisador (a) Executante: Denise Zakabi

CEP-FMUSP, 15 de setembro de 2010.

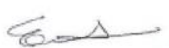

Prof. Dr. Eduardo Massad

Coordenador

Comitê de Ética em Pesquisa

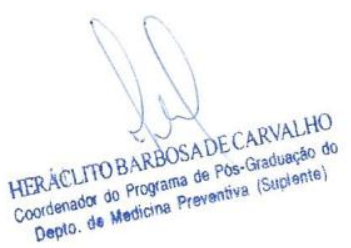

Comitê de Ética em Pesquisa da Faculdade de Medicina da Universidade de São Paulo Rua Ovídio Pires de Campos, 225, $5^{\circ}$ andar - CEP 05403010 - São Paulo - SP Fone: 01130696442 Fax: 01130696492 e-mail: cep.fmusp@henet.usp.br 


\section{ANEXO VI - APROVAÇÃO PELO COMITÊ DE ÉTICA EM PESQUISA DA SECRETARIA MUNICIPAL DA SAÚDE DA PREFEITURA DA CIDADE DE SÃO PAULO, PARECER No 328/10, CAAE: 0159.0.162.015-1}

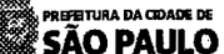

\section{SECRETARIA MUNICIPAL DA SAÚdE Comitê de Ética em Pesquisa/SMS}

São Paulo, 21 de Setembro de 2010 PARECER No 328/10 - CEP/SMS CAAE: 0159.0.162.015-10

\section{Ilma Sra}

Denise Zakabi

Projeto de Pesquisa: Aconselhamento pré e pós-teste anti-HIV na Atenção Básica: a perspectiva dos profissionais de saúde

Pesquisador responsável: Denise Zakabi

Instituição: Faculdade de Medicina Universidade de São Paulo

Local onde os dados serão coletados: Em São Paulo - em dois serviços de Atenção Básica na região Oeste : UBS Jardim Boa Vista e UBS Rio Pequeno. Em Fortaleza - na Regional III, situada em região periférica, nos Centros de Saúde Ivana Paes e George Benevides.

Patrocinador: $\mathrm{CNPq}$

\section{I - Sumário Geral do Protocolo}

O aconselhamento é uma importante estratégia para prevenção do HIV, por ser uma oportunidade de conversar sobre formas do sujeito se prevenir contra o HIV e sobre as implicações do resultado, tanto positivo, para ajudar a lidar com o tratamento e com suas implicações, como negativo, para continuar ou elaborar formas de manter o cuidado para não se infectar.

Estudos internacionais enfatizam a importância da ampliação da testagem e as implicações éticas relacionadas (OBERMEYER e OSBORN, 2007; PRIMARY, 2003).

Alguns estudos internacionais apontam que o aconselhamento realizado para pessoas de baixo poder aquisitivo apresentam alguns problemas que diminuem sua eficácia:

a) tempo insuficiente,

b) informação inadequada e

c) confidencialidade quebrada, como na Tailândia, nas Filipina: : e na Indonésia.

A prática do aconselhamento pré e pós-teste anti-HIV tem sido preconizada pelo Ministério da Saúde na Atenção Básica desde 1999, consonante com os princípios de integralidade e descentralização do SUS.

Estudos nacionais apontam que, em caso de resultado positivo, o aconselhamento, baseado na atenção, no respeito, na clareza das informações e na possibilidade de autonomia do paciente é importante para a adesão ao tratamento, mas apontam também que nem sempre o aconselhamento é realizado nestes termos. A testagem anti-HIV é considerada um procedimento de difícil incorporação à rotina dos técnicos da rede básica e o aconselhamento não é fundamentado teoricamente. Comumente, o aconselhamento é banalizado e por isso, muitas vezes não é um momento de discussão personalizada sobre dúvidas, riscos, atitudes e contextos sociais. (PAIVA et al. 2006)

Este estudo visa conhecer a perspectiva dos profissionais de saúde de serviços de Atenção Básica em relação a essas ações, em duas capitais em regiões brasileiras distintas: São Paulo e Fortaleza-CE.

Objetivo Geral - Conhecer as características do encontro/conversa entre profissional de saúde e usuário na Atenção Básica à Saúde, nas ações de aconselhamento pré e pós-teste anti-HIV. Com isso, busca-se analisar como e se a integralidade do cuidado se efetiva e como os serviços têm buscado reduzir a vulnerabilidade dos sujeitos envolvidos.

\section{Objetivos específicos}

$>$ Analisar se o encontro/conversa entre profissional de saúde e usuário na Atenção Básica à Saúde, nas ações de aconselhamento pré e pós-teste anti-HIV, é caracterizado por monólogos prescritivos ou diálogos, nos quais haja recon hecimento da alteridade e da subjetividade de cada usuário e se a saúde é buscada de maneira integral.

* Rua General Jardim, 36 - $1^{\circ}$ andar - V. Buarque - fone: 3397.2464 - email: smscep@gmail.com

http://www.prefeitura.sp.gov.br/cidade/secretarias/saude/comite_de_etica/ 


\section{SECRETARIA MUNICIPI L. DA SAÚDE Comitê de Ética em Pesquisa/SMS}

CAAE: 0159.0.162.015-10

$>$ Conhecer quais elementos são trabalhados para que os sujeitos conheçam situações de risco e lidem com aspectos relacionados aos planos da vulnerabilidade individual e social, como parte de uma estratégia de redução da vulnerabilidade programática, dentro de uma perspectiva ética do profissional.

$>$ Analisar se há diferenças nas formas de aconselhamento por características relacionadas à vulnerabilidade social, como gênero, raça/etnia, por geração e por classe social dos usuários e dos profissionais, de acordo com a percepção destes últimos.

O estudo será realizado em duas capitais brasileiras, de regiões sócio-culturais distintas: São Paulo e em Fortaleza. Serão pesquisados dois serviços de atenção básica em cada uma dessas capitais, com diferentes estruturas e contextos.

$>$ São Paulo - Duas UBS na região Oeste: UBS Jardim Boa Vista e UBS Rio Pequeno.

$>$ Fortaleza - Duas Unidades localizadas na Regional III, situada em região periférica, nos Centros de Saúde Ivana Paes e George Benevides, com a anuência da Secretaria da Saúde, dos gestores e profissionais de saúde. Caso seja recusada, serão buscadas outras UBS da mesma região.

Técnicas de coleta de dados:

Técnicas de produção das narrativas de campo - procє dimentos de caráter qualitativo, baseados em entrevistas em profundidade e observação participante a partir dos referenciais teóricos da vulnerabilidade à infecção pelo HIV (AYRES et al. 2003), do ponto de vista da emancipação psicossocial (PAIVA, 2002), do cuidado realizado (AYRES, 2001) e de espaços de acolhimento (TEIXEIRA, 2003) nos serviços.

A técnica de observação participante será utilizada para conhecer o contexto e as condições estruturais de trabalho no serviço de saúde. Será realizada através de roteiro específico (anexo III) e registrada através de um diário de campo, no qual deverão ser anotadas observações sobre conversas formais e informais, comportamentos, gestos e o contexto institucional. O roteiro pode ser mudado de acordo com a percepção de questões relevantes no campo (MINAYO, 2008).

Nas UBS, planeja-se observar o contexto da sala de espera, as atividades da equipe de enfermagem e dos médicos, incluindo-se as visitas domiciliares, por serem estes os profissionais que mais realizam o pedido e a comunicação do resultado de HIV, segundo ZAKABI e TEIXEIRA (1997). Entretanto, pode ser que sejam observadas outras atividades, de acordo com indicação dos profissionais da unidade. Também podem ser analisados documentos e prontuários dos serviços.

Serão realizadas entrevistas semi-estruturadas com: gerentes das unidades selecionadas, que aceitem participar da pesquisa; profissionais de saúde que realizam o aconselhamento, a princípio, membros da equipe de enfermagem, médicos, indicados pelos gerentes ou pelos próprios profissionais e outros profissionais que sejam indicados pelos entrevistados.

As entrevistas visarão buscar: treinamentos ocorridos; condições para aconselhamento; narrativas de casos em que os profissionais relatem verbalmente como foi realizado o pedido e a comunicação de resultado de HIV, a partir de sua memória, dificuldades e facilidades para realização destes.

O número e o tempo de duração de entrevistas será definido no decorrer do processo, quando os pesquisadores considerarem que obtiveram conhecimentos relevantes para os objetivos propostos. Estima-se a realização de 10 entrevistas em cada cidade, com duração aproximada de uma hora cada. Pretende-se entrevistar em cada UBS o gestor, uma enfermeira, um médico e um ou dois outros profissionais de saúde indicados pelos entrevistados que realizem o pedido e a comunicação de resultado de HIV, podendo ser outro médico, outra enfermeira ou técnica de enfermagem, uma psicóloga ou assistente social.

* Rua General Jardim, 36 - $1^{\circ}$ andar - V. Buarque - fone: 3397.2464 - email: smscep@gmail.com

http://www.prefeitura.sp.gov.br/cidade/secretarias/saude/comite_de_etica/ Página 2/3 


\section{SECRETARIA MUNICIPAL DA SAÚDE Comitê de Ética em Pesquisa/SMS}

CAAE: 0159.0.162.015-10

As entrevistas serão gravadas e posteriormente transcritas pela própria pesquisadora, que também realizará anotações num caderno de campo sobre as condições da entrevista e suas próprias impressões.

Para a análise do material coletado, visa-se realizar uma análise de conteúdo.

Critério de inclusão: Profissionais envolvidos no aconselhamento.

\section{II - Considerações}

A Folha de Rosto está corretamente preenchida e assinada. O currículo do pesquisador responsável está de acordo com a proposta da pesquisa. O Cronograma informa que a coleta de dados será iniciada em Outubro/10. Orçamento está adequado e informa que a própria pesquisadora arcará com os custos. Há tratamento adequado dos dados/informações

A metodologia é adequada aos objetivos, impõe alguma cor dição de risco/desconforto ao sujeito da pesquisa devidamente justificados no desenho da pesquisa.

$\mathrm{Em}$ parecer anteriormente emitido, foi solicitado que a pesquisadora esclarecesse se os usuários serão considerados sujeitos desta pesquisa. Foi decidido pela pesquisadora que somente serão realizadas entrevistas com os gestores e profissionais de saúde e descrição somente dos contextos dessas entrevistas.

Também foram solicitadas retificações no TCLE, que foi reescrito e considerado adequado.

\section{III - Situação do Protocolo: Aprovado}

Antes do inicio da coleta de dados, alertamos para a necessidade de contato com o gerente da unidade quando não foi ele quem autorizou a realização da pesquisa.

Salientamos que o pesquisador deve desenvolver a pesquisa conforme delineada no protocolo aprovado. Eventuais modificações ou emendas ao protocolo devem ser apresentadas ao CEP de forma clara e sucinta, identificando a parte do protocolo a ser modificada e suas justificativas.

$O$ relatório final deve ser apresentado ao CEP, logo que o estudo estiver concluído.

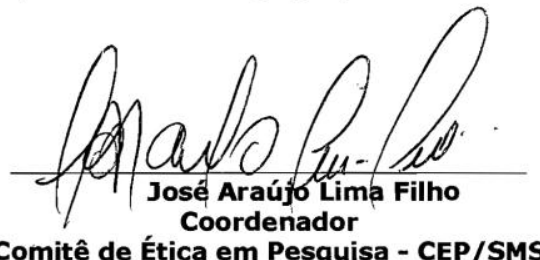

* Rua General Jardim, 36 - $1^{\circ}$ andar - V. Buarque - fone: 3397.2464 - email: smscep@gmail.com 